



\section{HISTORIA DE UN PASAJE-MUNDO \\ el estrecho de Magallanes en el siglo de su descubrimiento}

Mauricio ONETTO PAVEZ 
(C) Mauricio Onetto Pavez

Primera edición: julio de 2018

Segunda edición: enero de 2019

Inscripción Derecho Intelectual No 289.313

ISBN 978-956-8454-27-2

Diseñador/diagramador : Nicolas SYKaS

Corrector de texto: Sebastián SuTER GÁNDARA

Ilustrador/ restauración electrónica de imágenes: Nicolas SyKas

Ograma Impresores

http://www.ograma.cl/

Impreso en Chile / Printed in Chile 


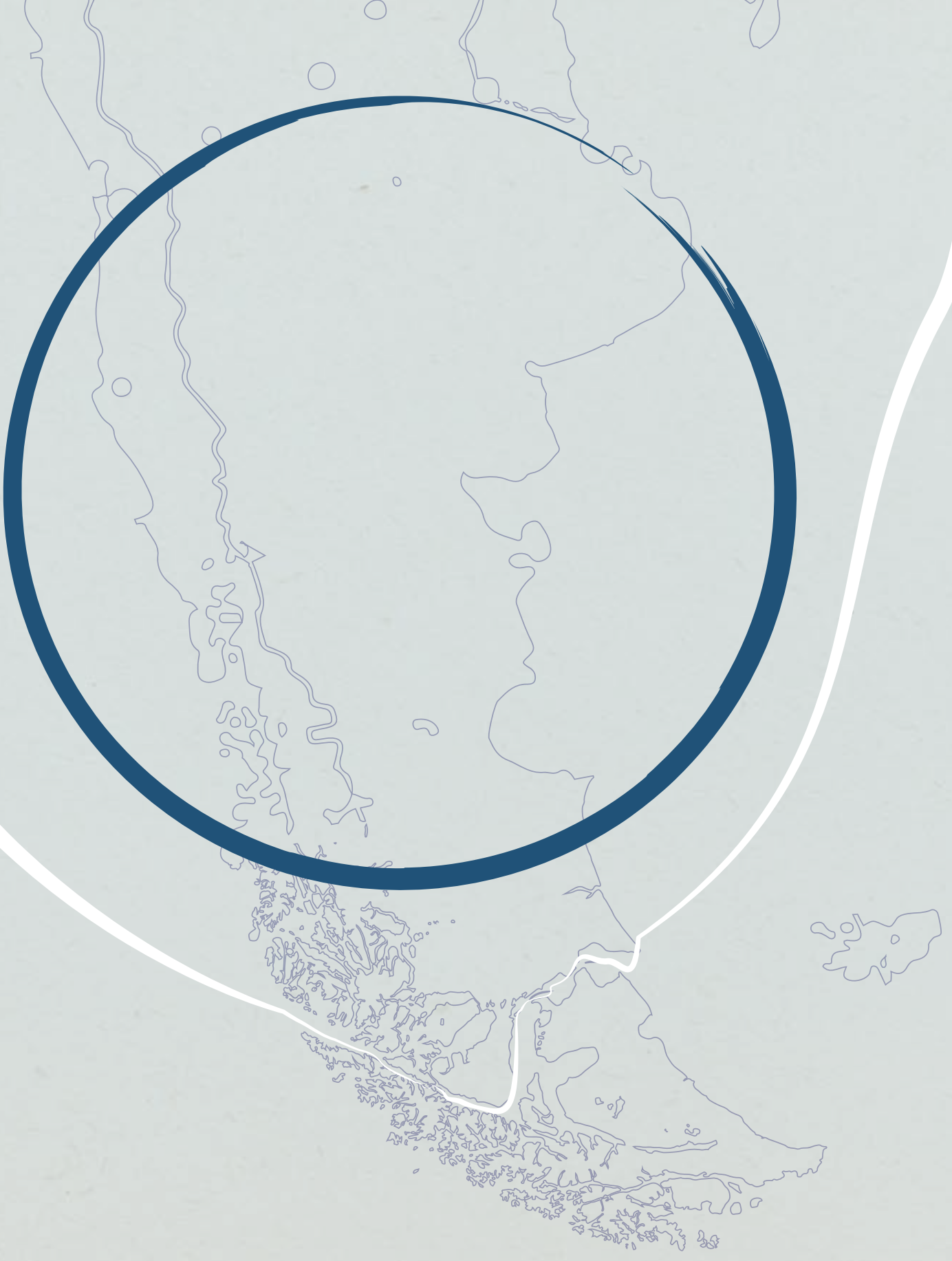

\section{HISTORIA DE UN PASAJE-MUNDO} el estrecho de Magallanes en el siglo de su descubrimiento 


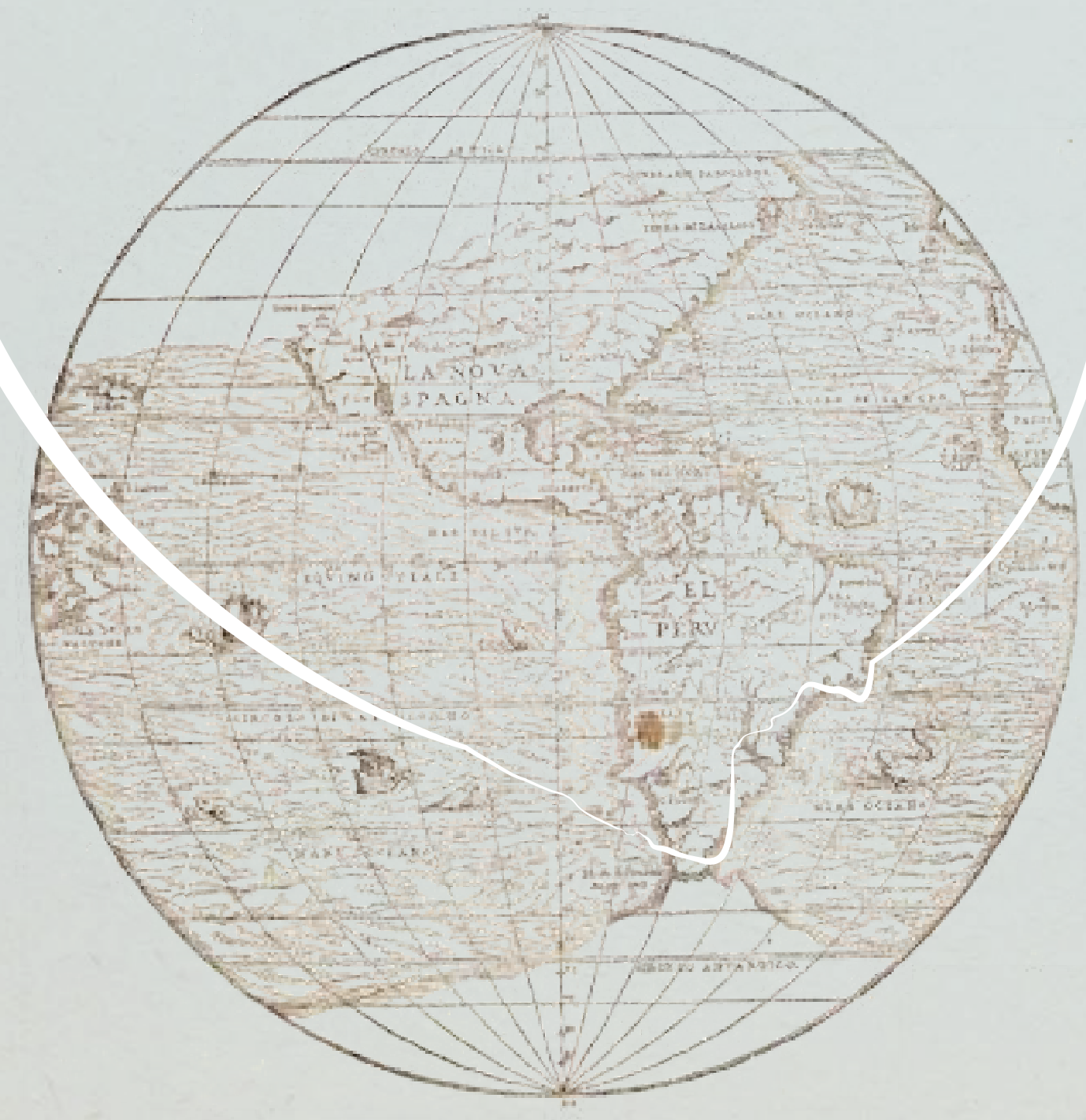

Este libro está dedicado a cuatros viajeros que inician su travesía, Almendra, Sue, Santino y Constantin. 


\section{Índice}

INTRODUCCIÓN .09

1 - La expedición de Fernando de Magallanes

y Sebastián Elcano (1518-1522)

2 - LA NOTICIA QUE CAMBIÓ EL PLANETA

3 - UNA NUEVA CONSCIENCIA DEL MUNDO Y DE LA HISTORIA TRAS EL DESCUBRIMIENTO DEL ESTRECHO DE MAGALLANES

4 - El estrecho de Magallanes, Constructor de territorialidades

5 - El Estrecho y “LOS SECRETOS DE LA TierRA”.

6 - La CONQUista de Chile, una EXCUSA PARA APRopiarse

Del estrecho de Magallanes.

7 - LOS PRIMERos CONOCIMIENTOS SOBRE EL ESTRECHO DE MAGALLANES: NAUfRAGIOS Y EXPLORACIONES DE OBSERVACIÓN.

8 - El Estrecho, una solución para la “Guerra de Chile”.

9 - UN PROBLEMA GEOPOLÍTICO: PIRATAS Y CORSARIOS INGLESES,

10 - El Estrecho COMO Un DEFINIDOR DE LA EXPERIENCIA

de “estar en Chile”

Conclusion.

BIBLIOGRAPÍA 


\section{Introducción}

$\mathrm{E}$ STE LIBRO, construido a partir de una investigación científica, busca proporcionar una de las tantas interpretaciones históricas que pueden realizarse sobre la importancia geopolítica del estrecho de Magallanes a lo largo del siglo XVI. Relevancia que, dentro de la presente edición, quedará expresada en términos planetarios, continentales (América) y en la conformación del propio territorio de Chile.

Ante la inminente conmemoración de los 500 años desde el "descubrimiento" oficial del Estrecho, al menos para el resto del mundo en aquella época, queremos convertirnos en una plataforma sobre la que se pueda reflexionar acerca de este pasajemundo, desde la perspectiva de la ciencia histórica. Creemos que la relevancia del "descubrimiento" del estrecho de Magallanes en I520 y el devenir de este paso geográfico durante el siglo XVI debieran ser más y mejor valorados en el aprendizaje formativo, puesto que consideramos estos hechos como parte fundamental de los acontecimientos forjadores y fundadores de la "mundialización" que desde esa fecha y hasta el día de hoy existe en el planeta.

Estamos convencidos de que la comprensión de cómo fue observado, anhelado, representado, etc., permitirá plantear nuevas preguntas en el proceso de aprendizaje, así como también ayudará a pensar la historia no solo en términos de guerras, hitos o personajes, sino desde otras perspectivas que resaltan la construcción de los espacios reales e imaginarios, la circulación por el mundo y el tema de las ilusiones humanas como centro del análisis. 


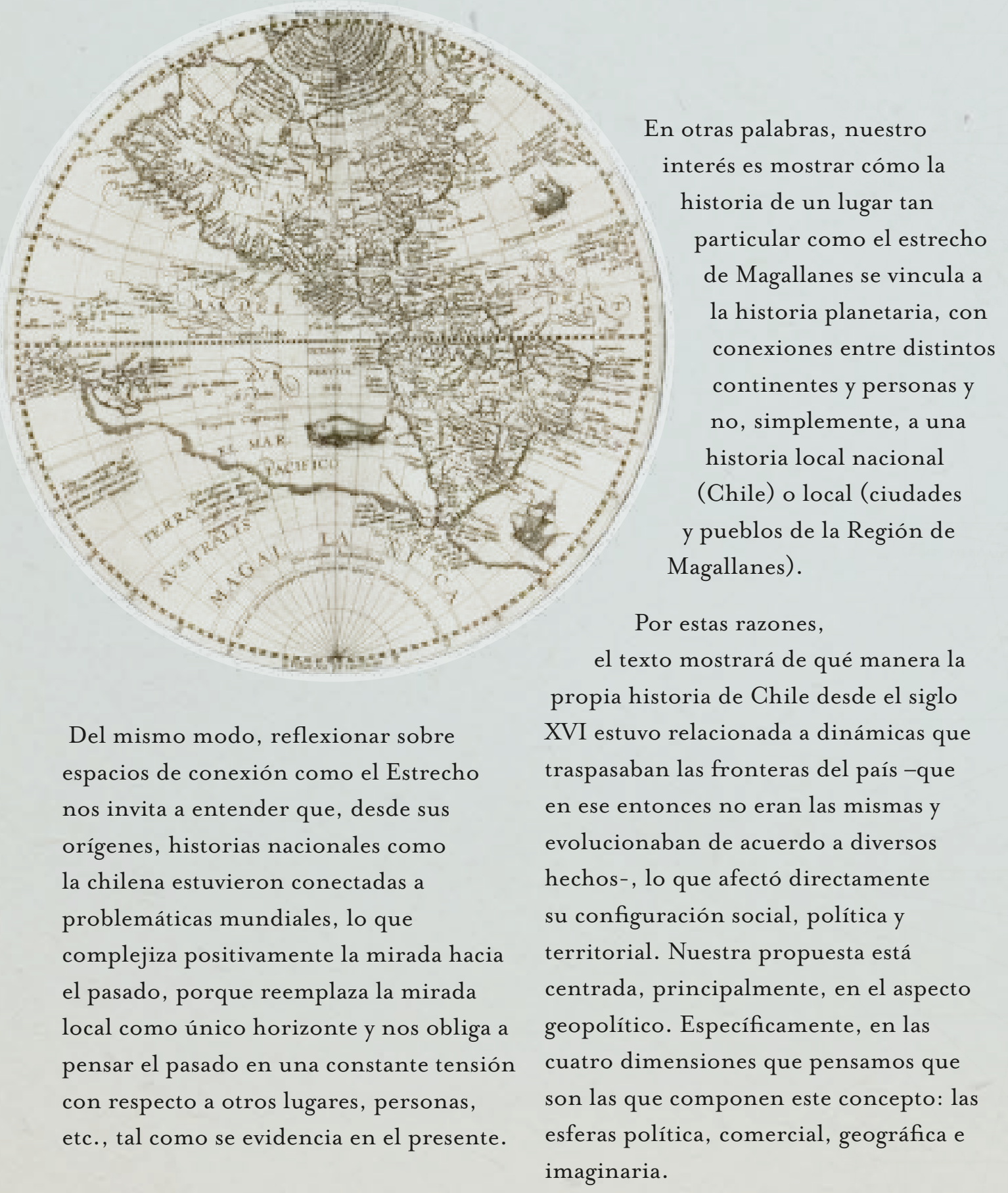


Lo anterior explica el hecho de que no nos adentremos en las consecuencias socioculturales ni ahondemos mayormente en las temáticas antropológicas. Tenemos muy presente la gran cantidad de comunidades nativas que ya vivían en la zona cuando la expedición dirigida por Fernando de Magallanes atravesó el Estrecho y las consecuencias negativas que trajeron para estos pueblos todos los cambios que examinaremos, no obstante, el objetivo puntual de este libro es enfocarnos en la perspectiva geopolítica.

Una serie de representaciones cartográficas se exponen para constatar y respaldar las interpretaciones.

Asimismo, se utilizan manuscritos de la época y una bibliografía actualizada, lo que permitirá que aquellas y aquellos que se interesen aún más en estos tópicos puedan indagar en ellos mediante la lectura de especialistas. Diversas personas e instituciones permitieron dar vida a este trabajo, aportando datos, entusiasmo o participando de las actividades académicas ligadas al proyecto científico que da soporte al texto. Nuestro reconocimiento para el Instituto Français Chile, el Centro Cultural de España, el Museo Regional de Punta
Arenas y LiquenLab. Nuestra máxima gratitud para Louise Bénat-Tachot, Serge Gruzinski, Andréa Doré, Carolina Martínez, Andrés Vélez, Luz Ángela Martínez, Flavia Morello, Paola Grendi, Sandra Ulloa, Ingrid Chanefo, Joaquín Zuleta, Nataniel Álvarez, Marcelo Mayorga y Kassandra Hernández.

Del mismo modo, deseamos agradecer a la Universidad Autónoma de Chile, que por medio de la Vicerrectoría de Investigación y Postgrado facilitó los medios para esta publicación. Sin este sostén no habríamos podido realizar este proyecto editorial. Asimismo, destacamos el papel de CONICYT, institución que financió a través de los proyectos Fondecyt de Iniciación No III50474 y GEOPAM (concurso "Apoyo a la Formación de Redes Internacionales para investigadores(as) en Etapa Inicial") la investigación que presenta esta obra.

Por último, queremos expresar nuestra amistad y el más sincero reconocimiento profesional para Nicolas Sykas y Sebastián Suter, con quienes creamos este bello trabajo. Sin la constancia, rigurosidad y creatividad de cada uno de ellos, este libro jamás habría sido posible. 
Pruma eqo velucolis ambiut Curfibus Orbem Magellane nouo to te duce ducta freto

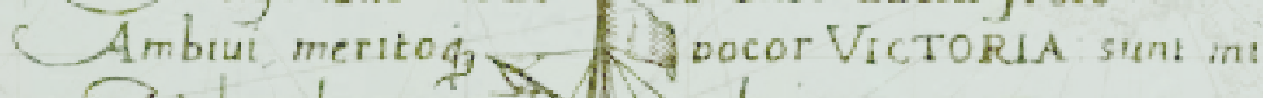
Vela, de procis. Ol gloria pugna mare.

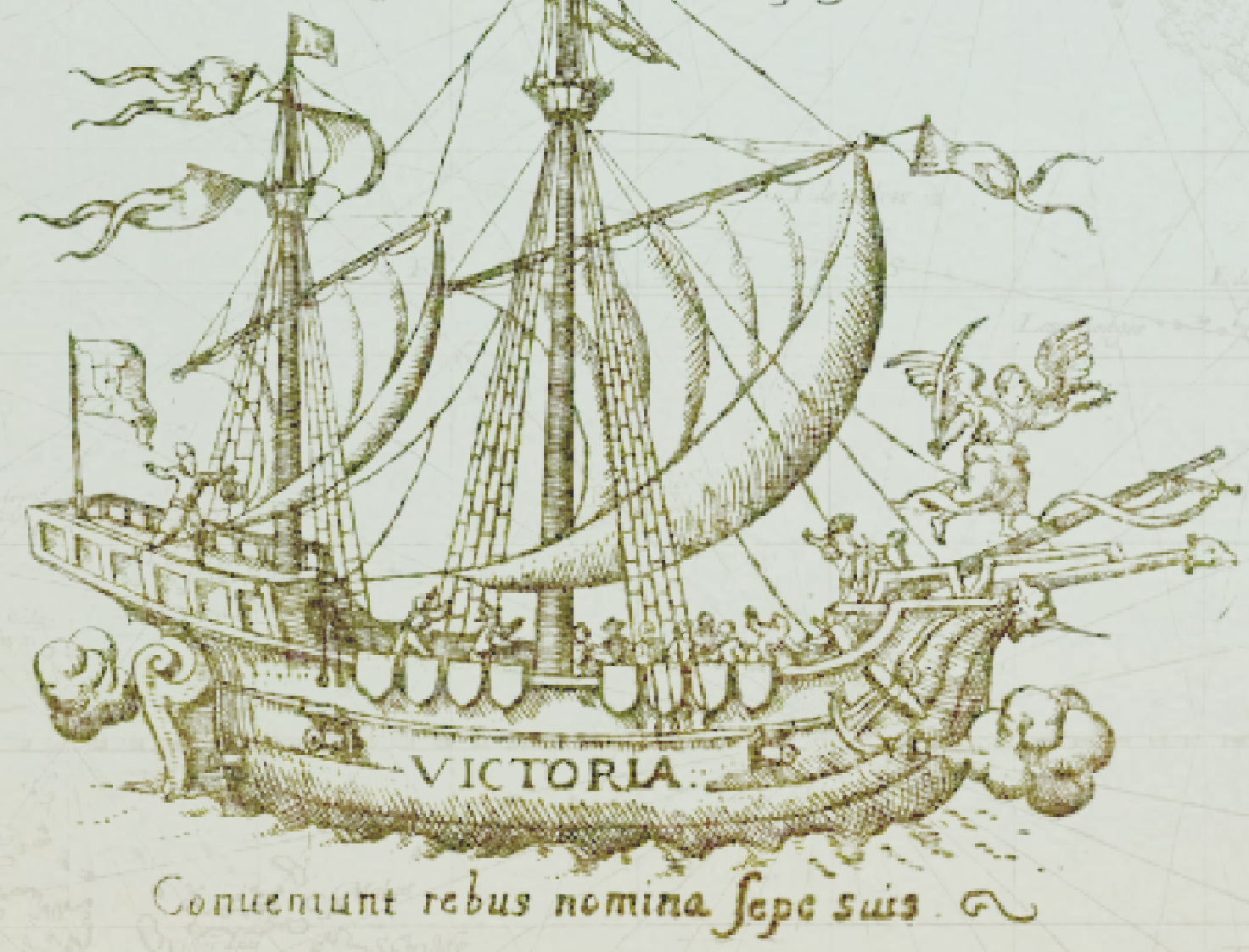


Capítulo 1

\section{La expedición de}

Fernando de Magallanes

y Sebastián Elcano

$$
\text { (I5I8-I522) }
$$




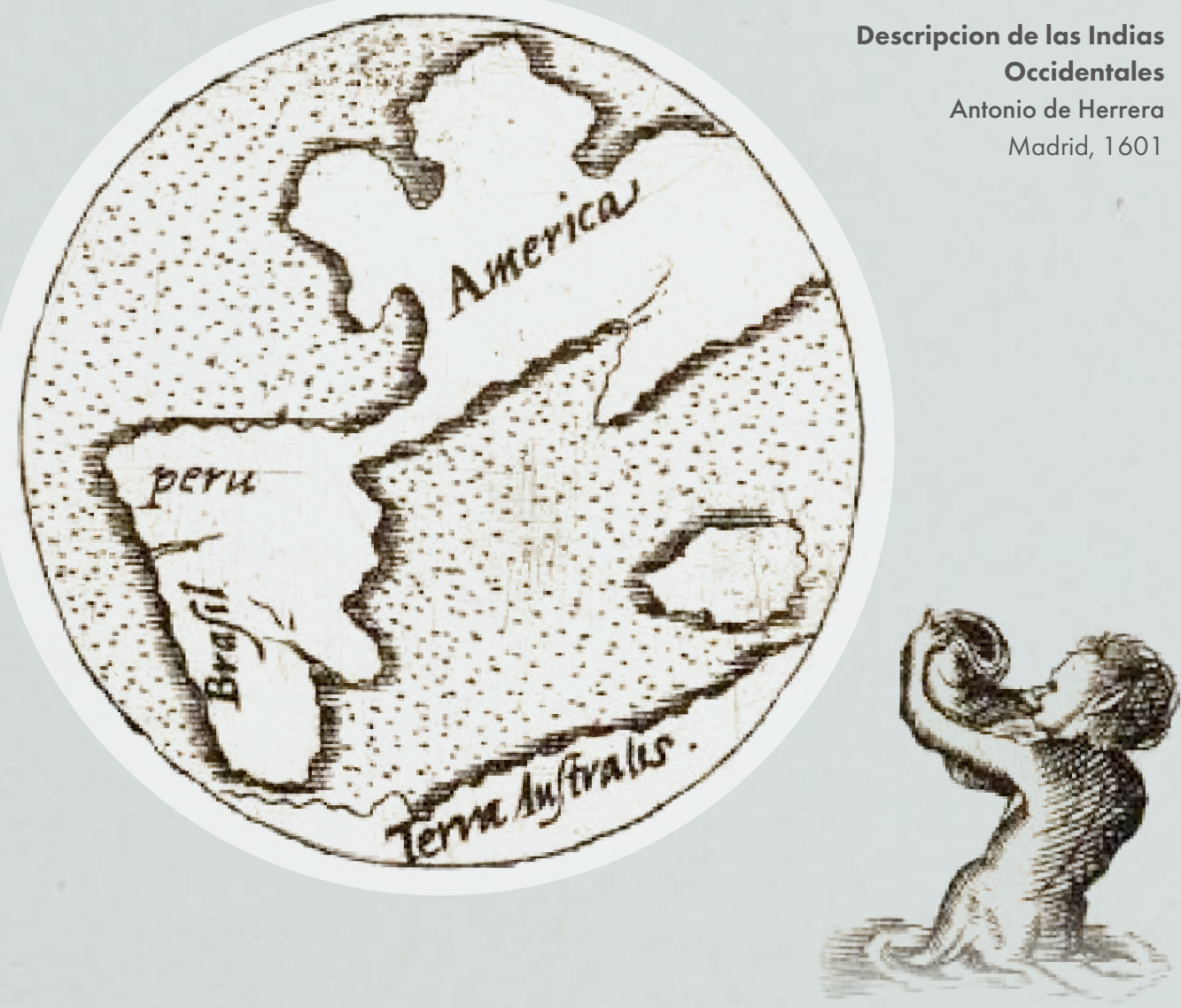

$\mathrm{E}$

L “DESCUBRIMIENTO” DEL estrecho de Magallanes en I520 es el punto álgido

de la carrera expansionista -por afanes comerciales y posicionamiento territorial-iniciada en el siglo XV por los reinos europeos. Si bien es cierto que las "cuatro partes del mundo" ya habían comenzado a interactuar gracias a la "aparición" de América, como diría el historiador Serge Gruzinski, desde que el Estrecho fue develado es que la expansión y conectividad encontraron su apogeo, debido a que se comenzó a operar en todos los ámbitos de manera planetaria y con una velocidad moderna, tal como la conocemos hoy.

Estos acontecimientos, sin duda, generaron un replanteamiento general de la geopolítica mundial. Los grandes beneficiados con el descubrimiento del estrecho de Magallanes fueron el emperador Carlos V y España, en desmedro de Portugal. 
La corte española se vio obligada a reforzar una serie de "disposiciones normativas", "capitulaciones militares", "reales provisiones" y a crear medidas para las nuevas tierras de ultramar. Todo esto produjo malestar en los portugueses, ya que ellos habían sido los pioneros del expansionismo y, además, porque Fernando de Magallanes, quien era en parte el responsable de este «descubrimiento», era de esa nacionalidad.

Como indican Carmen Bernard y Xavier de Castro respecto al conocimiento de la navegación, desde la segunda mitad del siglo XV hasta inicios del siglo XVI, eran los portugueses los que corrían con ventaja por sobre cualquier reino europeo, debido a sus "técnicas de construcción naval y su ciencia náutica”.

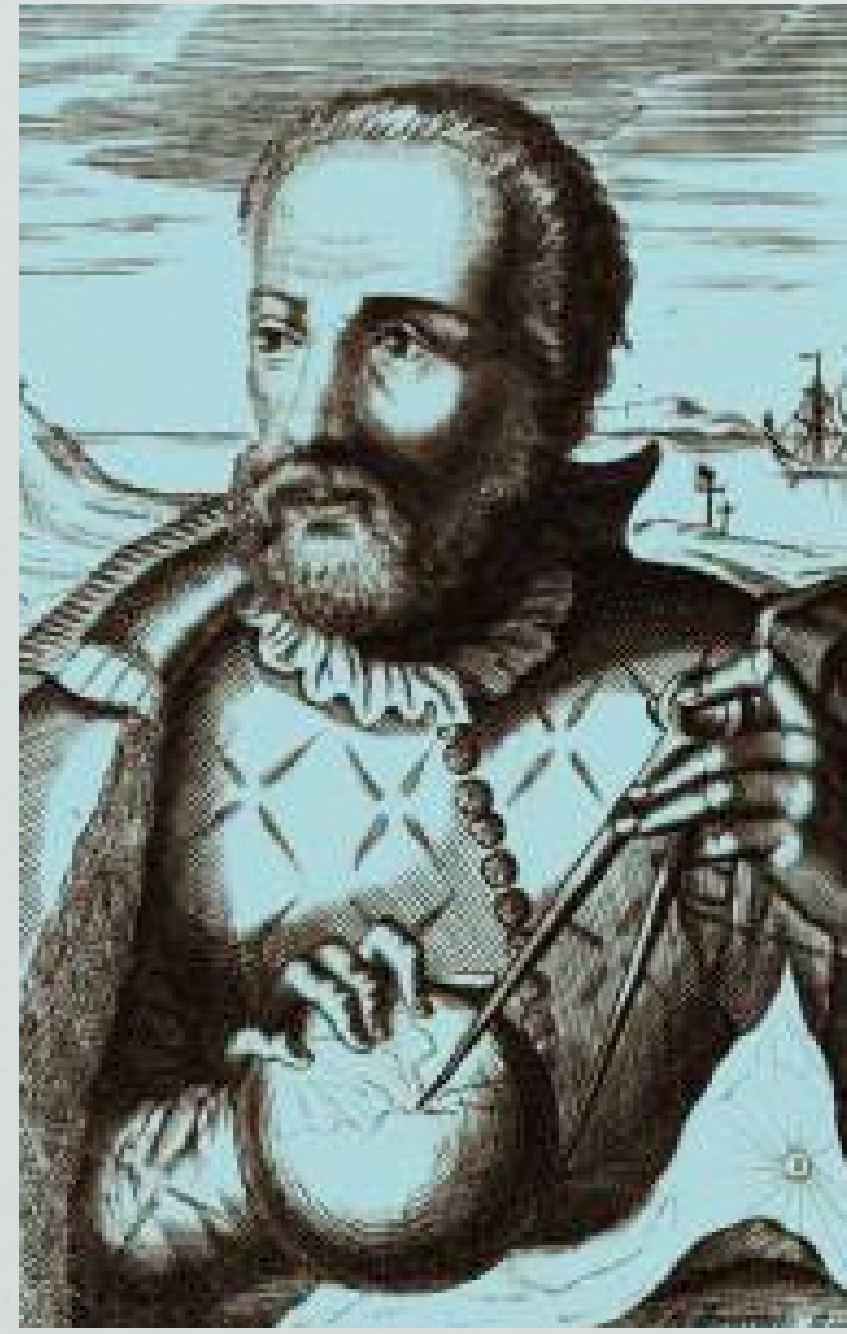

Fernando de Magallanes Pieter Balthazar Bouttats Amberes, 1728

Desde el develamiento del Estrecho, Portugal y España, las potencias colonizadoras de la época, se enfrascaron en disputas diplomáticas en torno a los acuerdos refrendados en el Tratado de Tordesillas (I493), lo que acarreó desacuerdos que finalizaron recién con el Tratado de Zaragoza en I529. 


\section{La importancia de las especias y el comercio}

Globo que muestra la zona del estrecho de Magallanes antes de su descubrimiento Johannes Schöner Núremberg 1515
Respecto al afán expansivo, el deseo de llegar a Oriente lo determinó la comercialización de las especias, cuya importancia no fue conservar la comida, como se ha transmitido desde hace décadas, sino entregar un conjunto de sensaciones, olores, concepciones de salud, prestigio y prácticas culinarias y de moda con las que eran asociadas.

Como menciona Paul Freedman, las especias "fueron maravillosas y misteriosas (1) necesarios para ir a Oriente a través de una nueva ruta de la que tenían noticias.

La Capitulación se firmó el 22 de marzo de ese mismo año. 


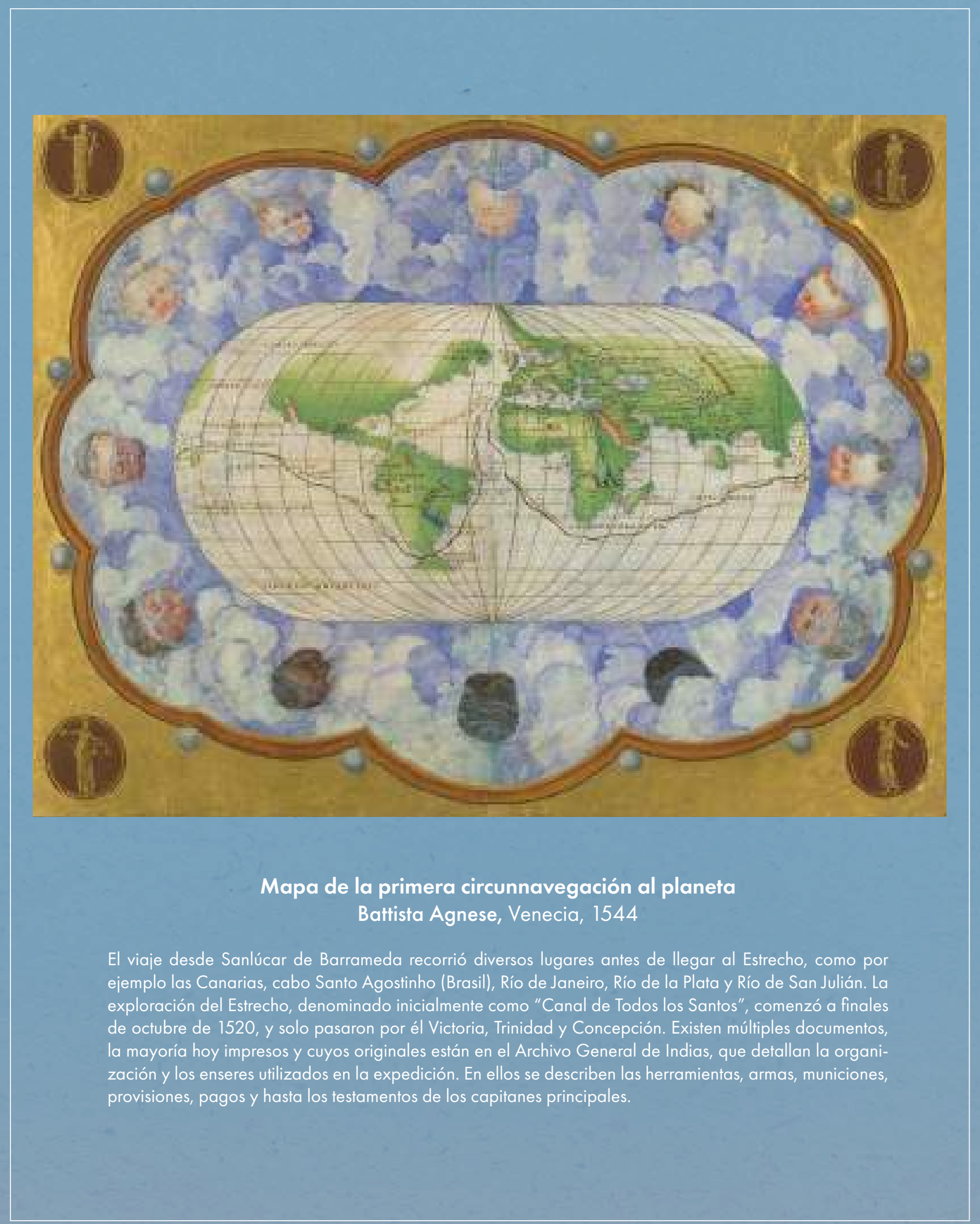


8XзTENTMONE

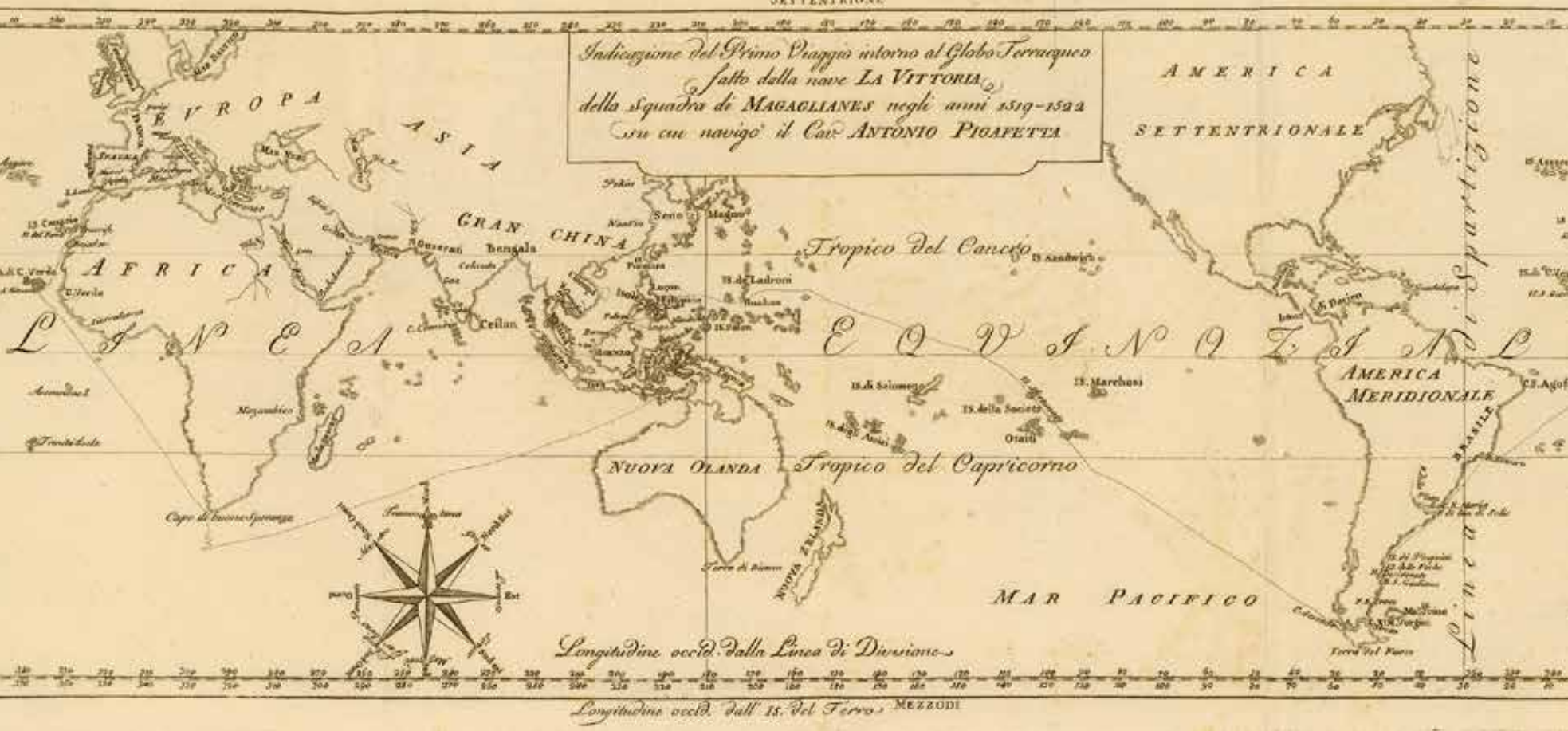

\section{Indicazione del Primo Viaggio intorno al Globo Terracqueo fatto dalla nave La Vittoria della Squadra di Magaglianes negli anni 1519-1522 (mapa inspirado en descripción Pigafetta) \\ Antonio Pigafetta, Milan, 1800}

El relato más conocido sobre la primera circunnavegación, en italiano original y traducido rápidamente a múltiples lenguas, es el del caballero de Rhodes, Antonio Pigafetta.

Sus notas, terminadas en 1524, se publicaron en formato libro en 1536 con el título de Relazioni in torno al primo viaggio di circumnavigazione. Notizia del Mondo Novo con le figure dei paesi scoperti.

El texto describió algunas impresiones sobre el paso por el Estrecho, y destacamos de él la siguiente nota: "Llamamos a ese estrecho el «Estrecho Patagónico»; en el cual, se encuentran, cada media legua, puertos segurísimos, inmejorables aguas, leña-aunque solo de cedro-, peces, sardinas, mejillones y apio, hierba dulce -también otras amargas-. Nace esa hierba junto a los arroyos y bastantes días solo de ella pudimos comer. No creo haya en el mundo estrecho más hermoso ni mejor". 


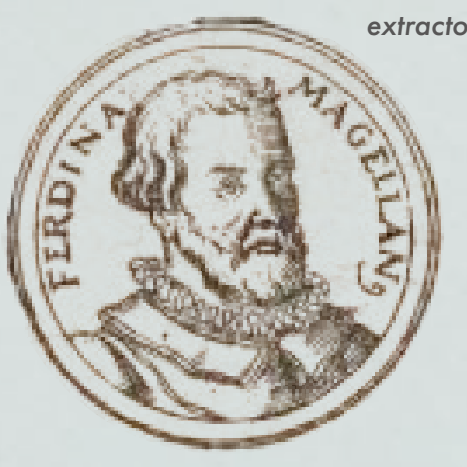

De acuerdo al secretario de Carlos V, Maximilianus Transylvanus, ambos navegantes pospusieron al Rey que enviase sus naos y armadas por "la parte de los mares de occidente, bajando al otro hemisferio", idea que el Rey y sus consejeros consideraron inicialmente como "dificultosa y de vanidad". Sin embargo, finalmente la expedición fue autorizada. Es más, al ver la magnitud de la empresa en caso de éxito, la Corona decidió financiarla en gran parte. El resto de los gastos fueron aportados por los contactos que tenían los solicitantes tanto en Alemania como en otras partes de Europa.

A pesar de los recursos que recibieron, no fue fácil formar la expedición debido a que Magallanes era portugués, e incluso se cree que el propio Rey de Portugal se involucró en boicotearla, aun después de que él mismo la rechazó cuando los navegantes le solicitaron apoyo.

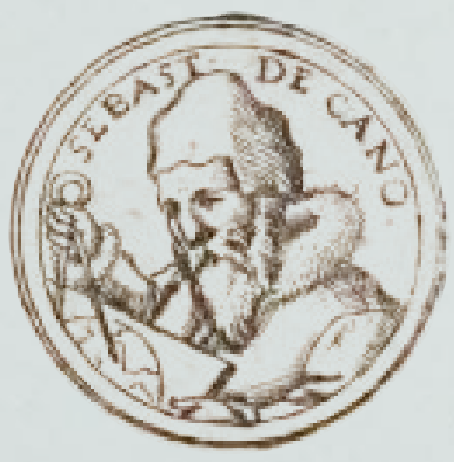

Si bien la expedición estuvo formada por 237 personas originarias de toda Europa, distribuidas en cinco barcos: la Victoria, la Concepción, San Antonio, Trinidad y Santiago, a la vuelta a Sevilla, ocurrida el 8 de septiembre de 1522 , solo quedaba una nave, la Victoria, y I8 tripulantes vivos, dentro de los que no estaba Fernando de Magallanes, muerto en abril de I52I luego de una disputa con los nativos de la isla Cebu.

Fue Juan Sebastián Elcano quien llegó a cargo de la nave sobreviviente y el responsable del comercio y de los beneficios que se pudiera obtener. Por esta razón es que la figura del navegante se alza como gran referente de la hazaña, y la nao Victoria como su representación repetitiva y simbólica en el tiempo.

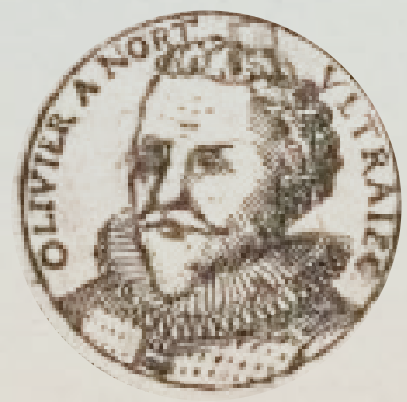




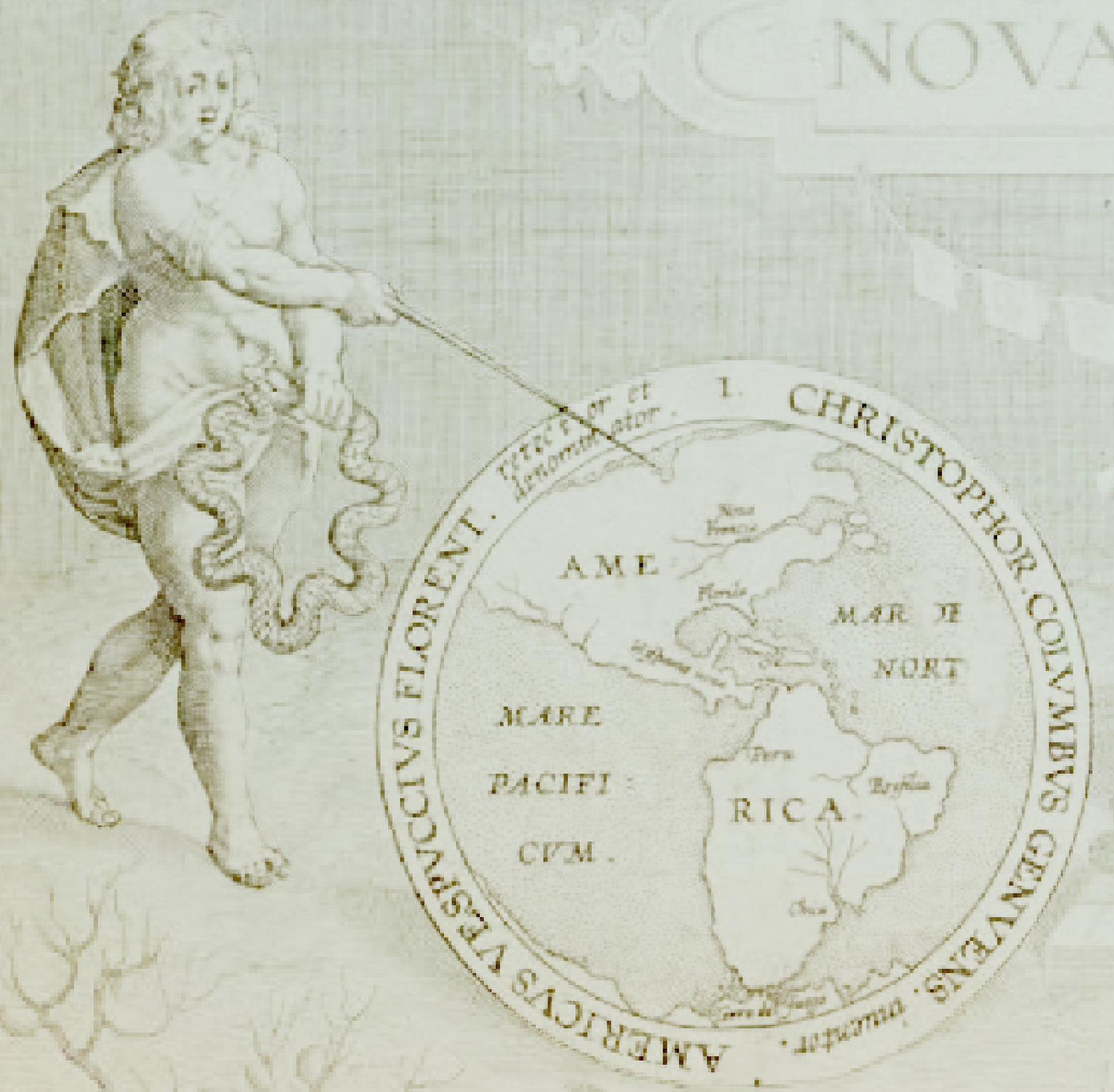




$$
\begin{gathered}
\text { Capítulo } 2 \\
\text { La noticia que } \\
\text { cambió el planeta }
\end{gathered}
$$




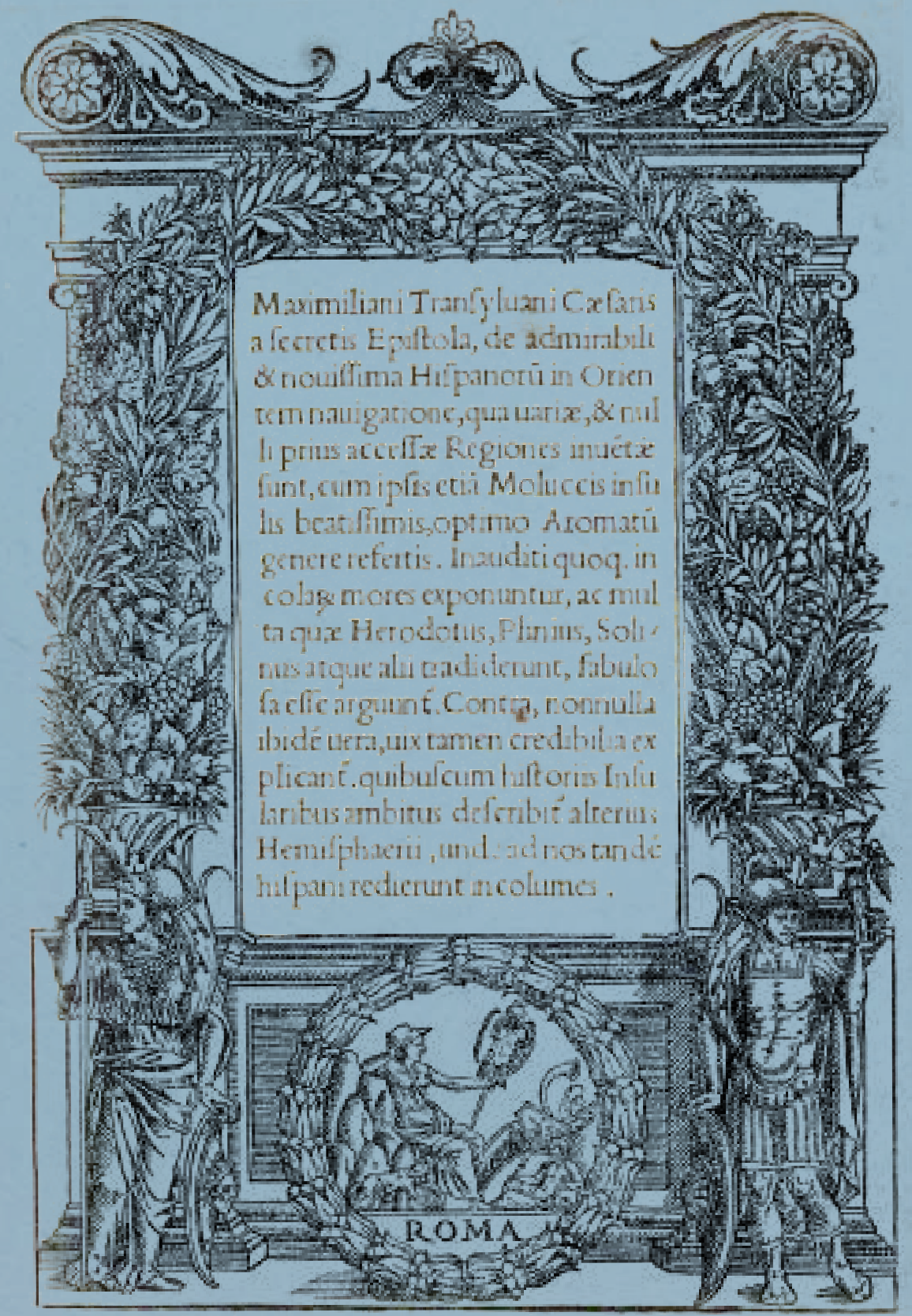

\section{Portada de la carta}

Maximilianus Transylvanus, Valladolid, 1522

El título original de la carta escrita en 1522 es Maximiliani Transyluani Caesaris a Secretis Epistola, de Admirabili \& Novissima Hispanoru[m] in Orientem Navigatione, Qua Uariae, \& Nulli Prius Accessae Regiones Inue[n]tae Sunt, Cum Ipsis Etia[m] Moluccis Insulis Beatissimis, Optimo Aromatu[m] Genere Refertis: Inauditi Quoq. Incolar[um] Mores Exponutur, Ac Multa Quae Herodotus, Plinius, Solinus Atque Alii Tradiderunt, Fabulo Sa Esse Arguunt. Contra, Nonnulla Ibide[m] Uera, Uix Tamen Credibilia Explicant. Quibuscum Historiis Insularibus Ambitus Descrebit Alterius Hemisphaerii, Unde Ad Nos Tande[m] Hispani Redierunt Incolumes. 


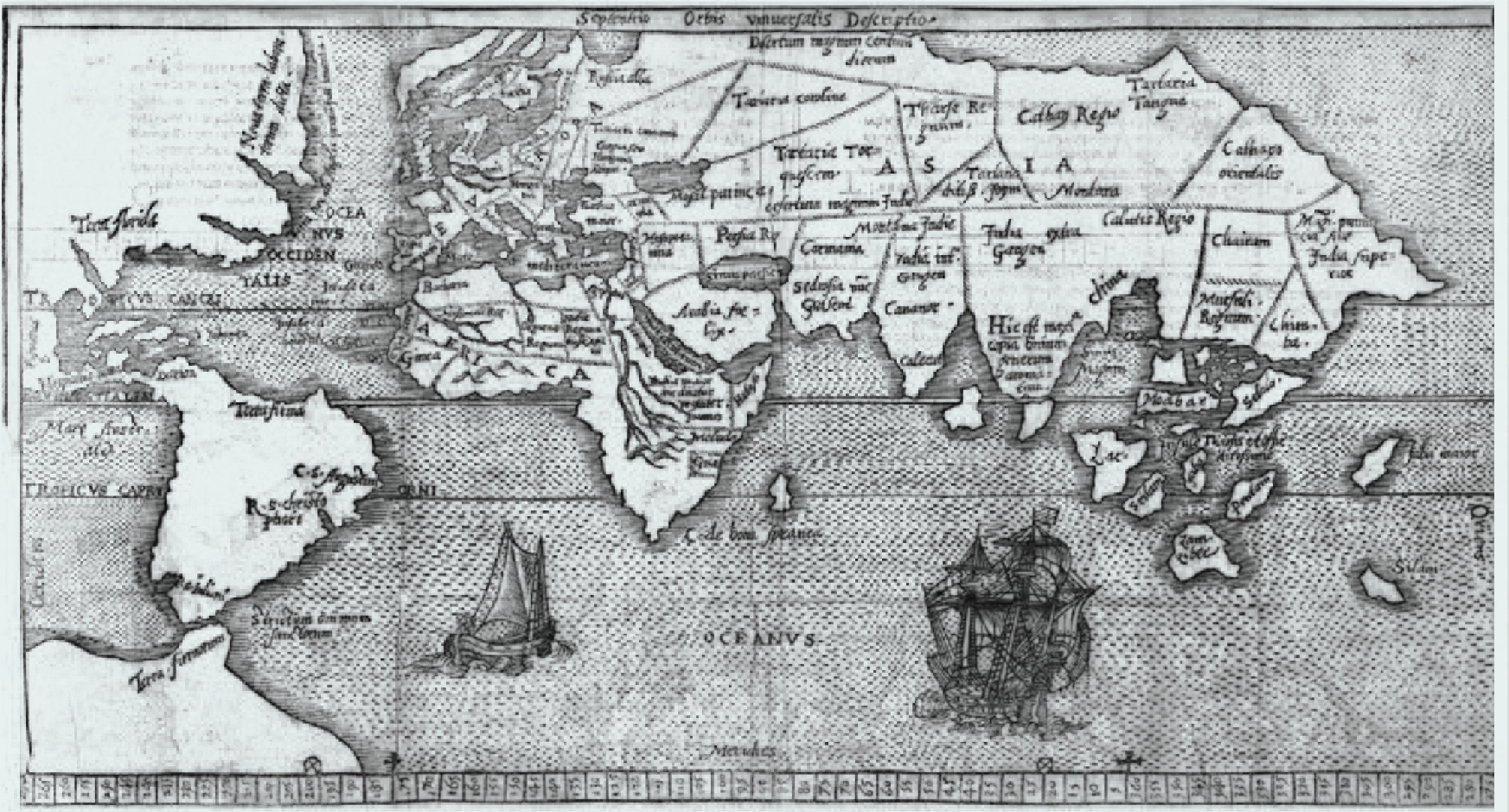

Orbis Universalis Description

Thomas Woodstock

Londres, 1582

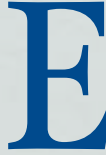

N EL AÑO I522, el secretario de Carlos V, Maximilianus Transylvanus, le escribió una carta a Mattaüs Lang, arzobispo de Salzburgo, actualmente en Austria. En dicha carta, le informó que gracias a la expedición dirigida por Fernando de Magallanes España poseía ahora nuevas tierras: las afamadas y "verdaderas" islas Molucas. Y aunque esta información resultaba ser muy importante, más notable aún fue una segunda noticia que entregó en la misiva: la expedición había descubierto un pasaje para acceder a Oriente, hasta el momento impensado, que ahora conocemos como el estrecho de Magallanes.
Hoy es sabido que la apertura del Estrecho como paso de navegación fue crucial para el porvenir del mundo moderno, ya que su descubrimiento por parte de los españoles desencadenó una revolución a escala global al conectar, por primera vez, todos los puntos de la Tierra.

Maximilianus, capaz de entender esto con claridad, consideró que la mejor estrategia para desarrollar el nuevo potencial a favor de la Corona era compartir la noticia utilizándola como propaganda política. 
De esta forma, auguró proyectos de expansión económica-territorial y de universalidad para el entonces emperador Carlos V. Con dicha propaganda, pretendía que todas las cortes europeas se informaran de esta gran noticia que beneficiaba a su Rey y también motivar a los distintos sostenedores de la Corona, como banqueros, comerciantes, marinos, científicos y universidades, a invertir en lo que había más allá de las fronteras conocidas.

\section{El mundo se transforma en Tierra}

En el texto, el secretario exhibe el viaje dirigido inicialmente por Magallanes como el más importante de la historia, tanto porque definió nuevos límites del planeta como porque se trató de una proeza de la navegación. Esta era la primera expedición que había logrado dar la vuelta mundo, algo que superaba con creces lo hecho por célebres navegantes antiguos como Jasón y sus argonautas, referentes náuticos desde antaño pero cuyas hazañas se limitaban al mar del Ponto. Transylvanus aventuró que el paso por el Estrecho consolidaba una nueva forma de percibir y transitar la Tierra, ahora completa tanto en su dimensión geográfica como cosmográfica. Los contornos del globo,

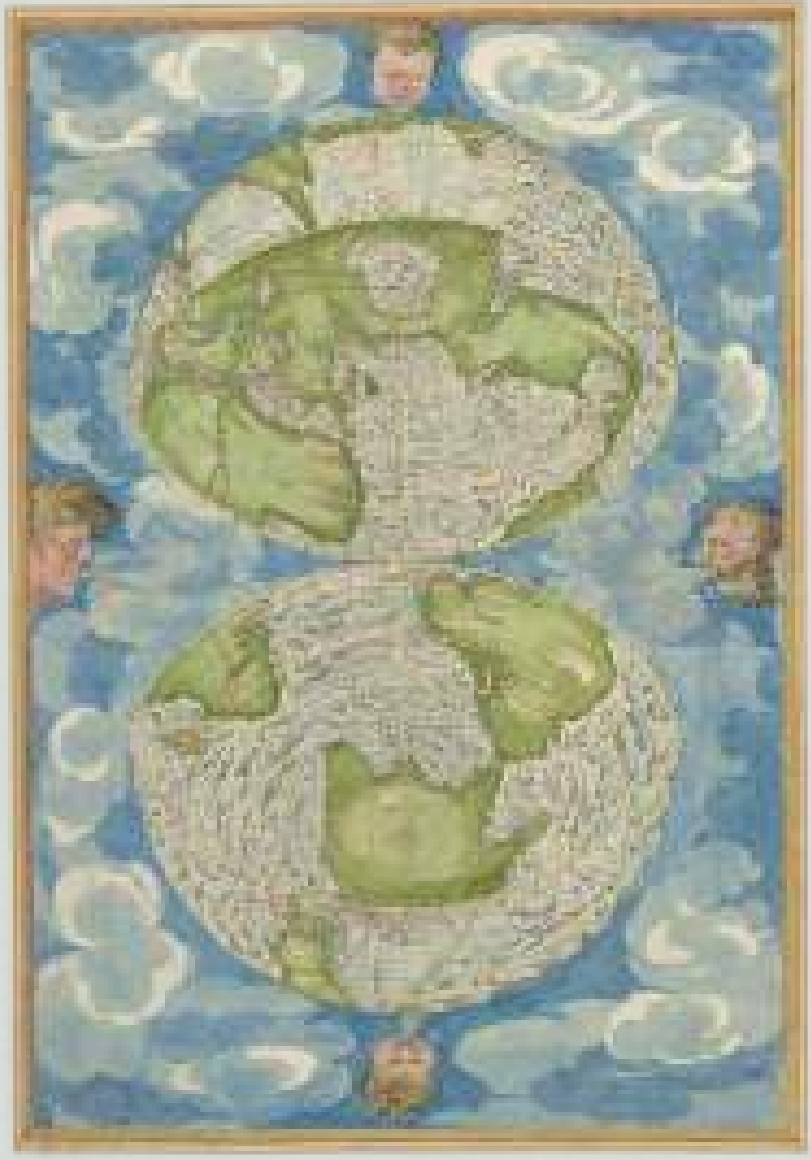

Cosmographie universelle selon les navigateurs tant anciens que modernes Guillaume Le Testu Le Havre, 1556

finalmente, quedaban definidos por medio de una nueva experiencia de circulación.

\section{Medidas antiguas, medidas inciertas}

Ahora bien, con respecto a las dimensiones del globo, la carta de Maximilianus cuenta cómo antes de su viaje Fernando de Magallanes y el mercader Cristóbal de Haro ya intuían 
que las medidas del planeta que se tenían como ciertas no lo eran, y que, por lo tanto, había territorios que debían estar dentro de la partición de Castilla y no de Portugal.

De hecho, este fue uno de los argumentos que los navegantes le presentaron al rey cuando le pidieron que auspiciara la empresa. Sin embargo, a pesar de que su hipótesis se basaba en un conocimiento nutrido por múltiples fuentes y en su experiencia, no lograron convencer a la totalidad de la corte, lo que no impidió que lograran el permiso y financiamiento necesario para poner en marcha la empresa.

$\mathrm{Al}$ regreso de su vuelta por el globo, sin embargo, se confirmaron las suposiciones de los navegantes. Los cálculos anteriores de la superficie terrestre eran incorrectos

\section{Claudio PTOLOMEO $100-175$}

Claudio Ptolomeo nació en Egipto y desarrolló su actividad durante el siglo II $\mathrm{d}$. C. Destacó en las áreas de astronomía, matemática, química y geografía. Además, fue un gran divulgador de la ciencia astronómica en la antigüedad. En este campo es que propuso la teoría geocéntrica que predominó durante siglos.

Dentro del conjunto de sus obras, tales como Hipótesis planetaria, Analemna, Óptica, Planisferio y Las fases astronómicas, resalta Geografía, que fue la base de la cartografía hasta el siglo XV, momento en el que Cristóbal Colón llegó a América por error siguiendo las indicaciones del libro.

Si bien los cálculos de Geografía fueron corregidos, muchos de los conceptos introducidos en el libro siguen vigentes hasta hoy, como por ejemplo la descripción del mundo en grados y minutos. y ahora habían sido corregidos. Esto significó romper con el modelo cartográfico de Ptolomeo, vigente desde hacía siglos y que hasta el momento era referencia obligada de los navegantes.
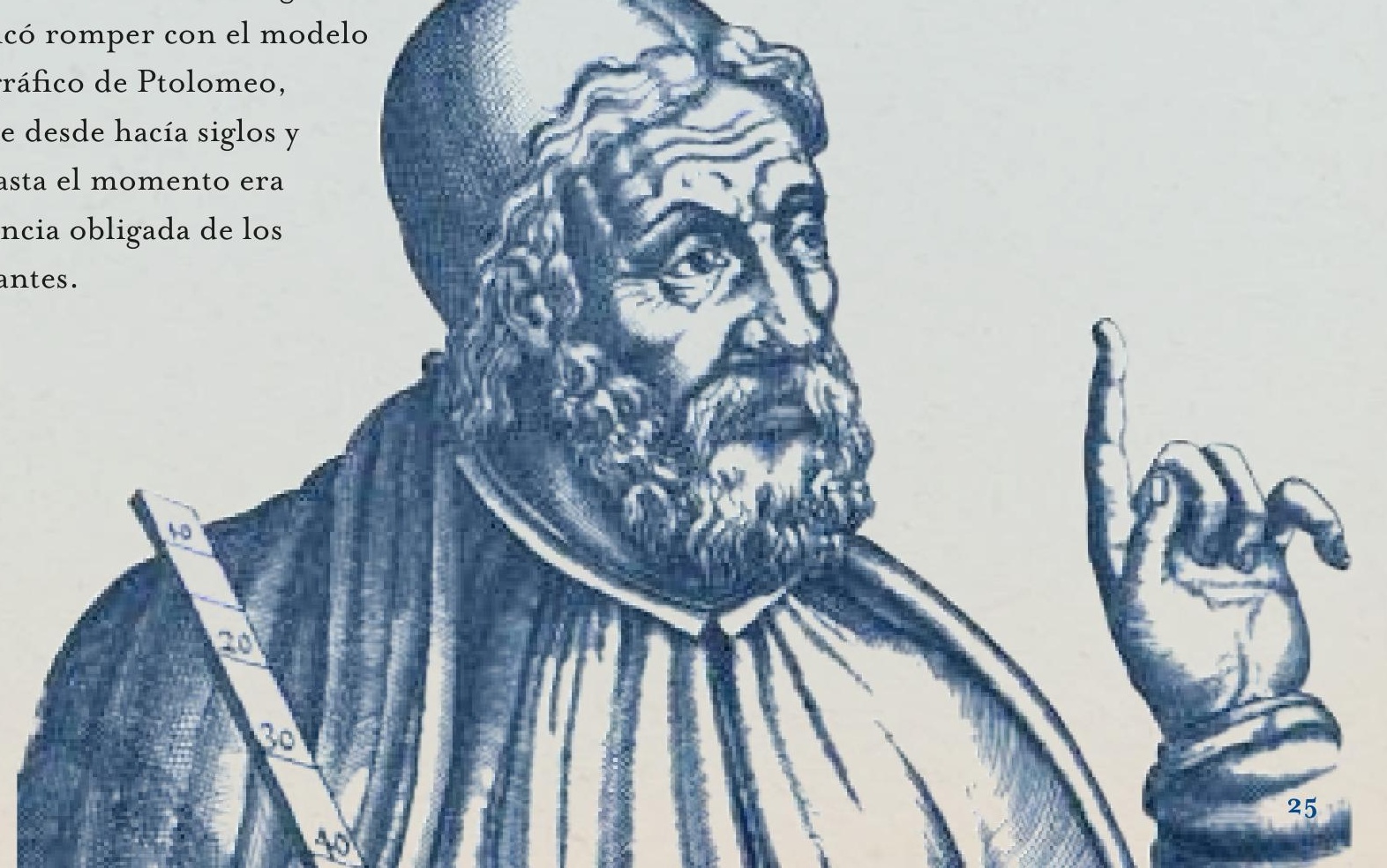


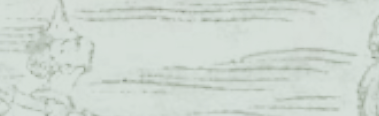

$13 \sqrt{c^{2}}$

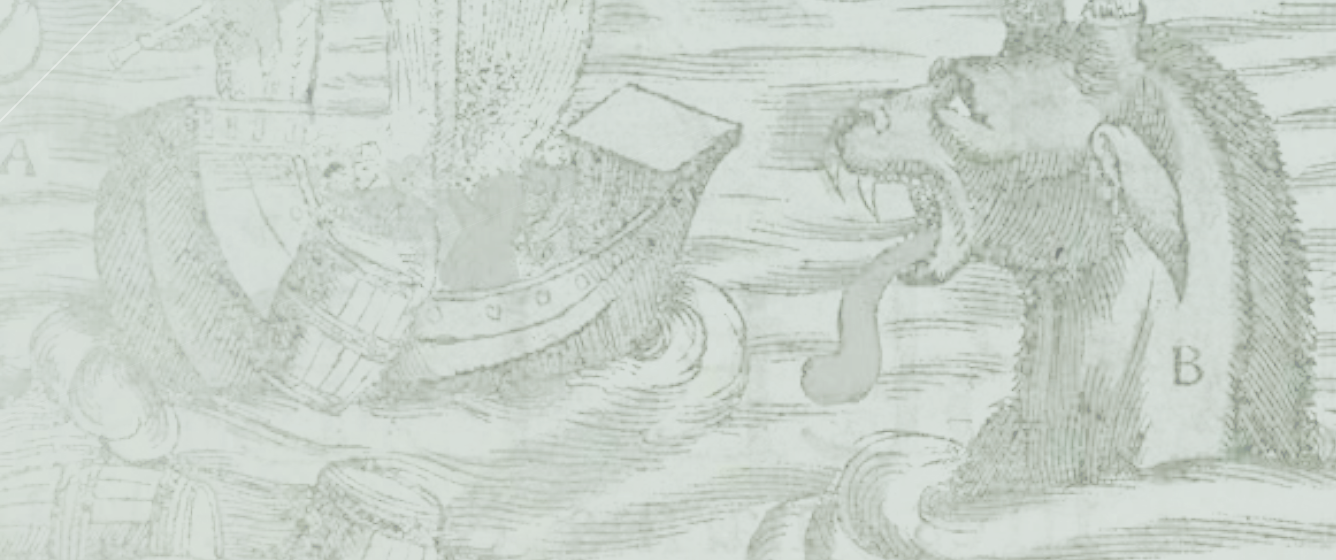

$+\left(\frac{3}{2}\right)$

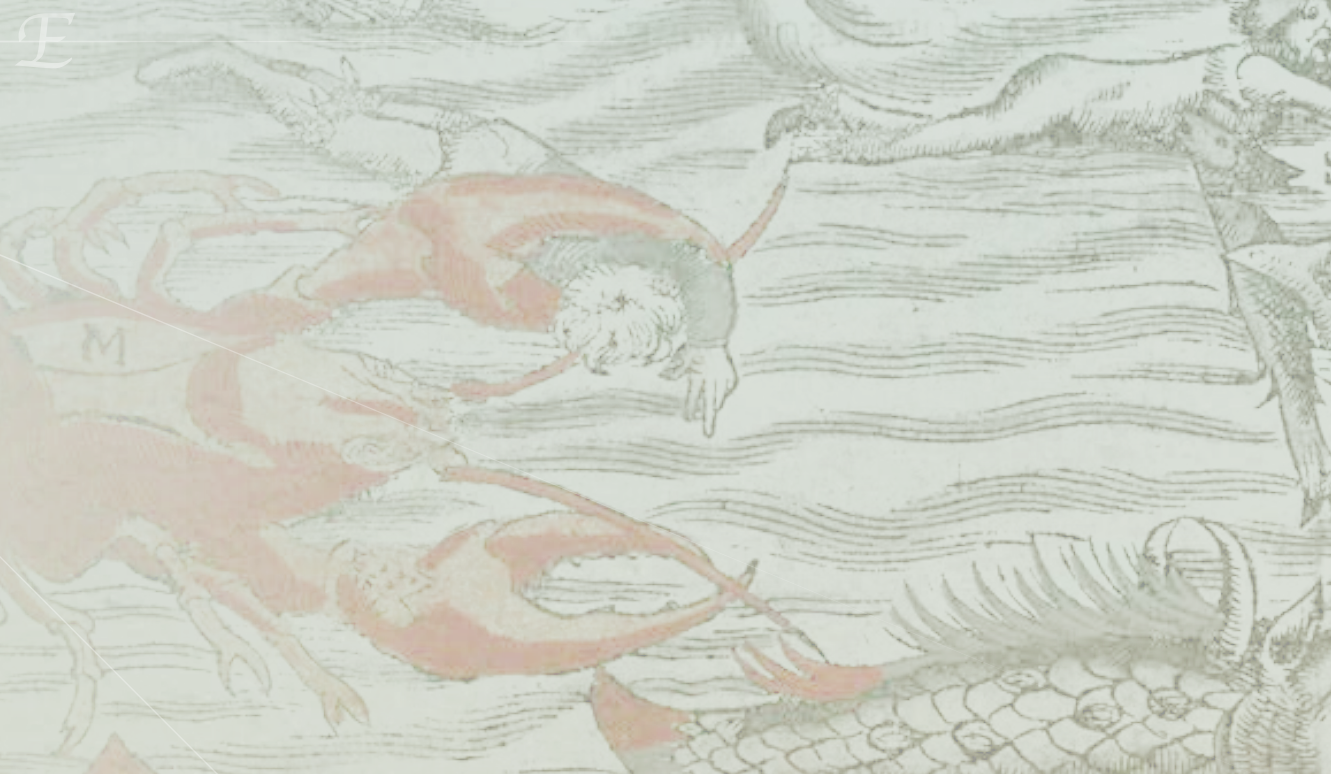

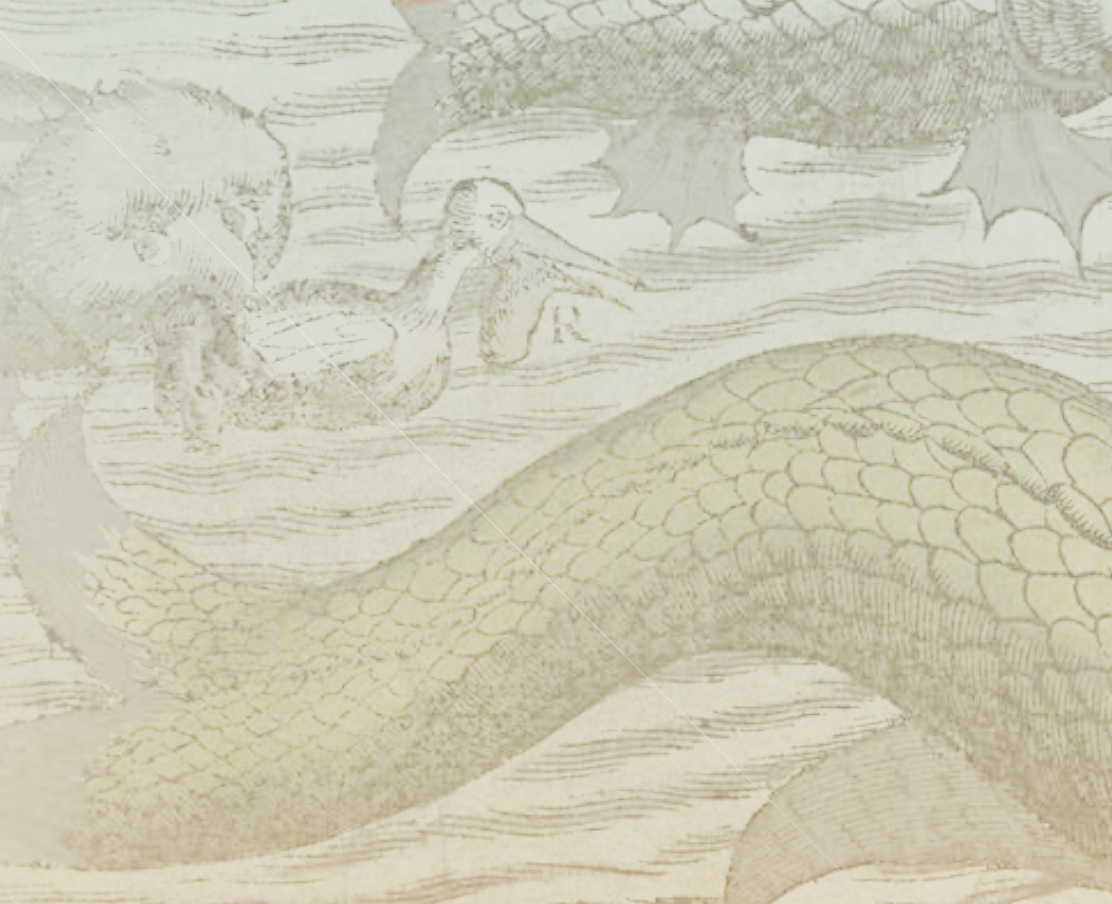


Capítulo 3

Una nueva consciencia del mundo y de la historia tras el descubrimiento del estrecho de Magallanes 


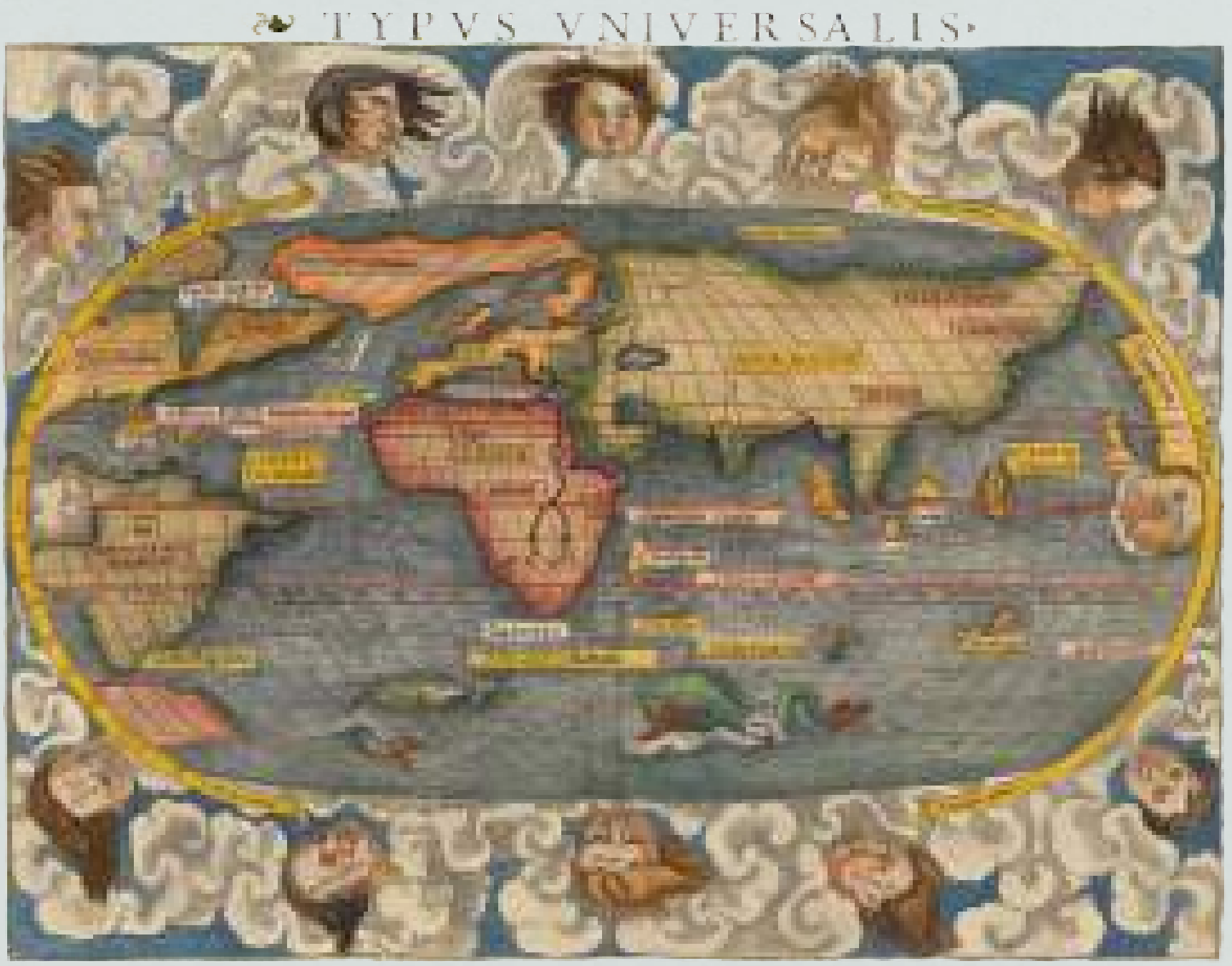

Das Erst General

Sebastian Münster Basilea, 1550

\section{Un cambio en el tiempo y de historias}

La ruptura con algunos postulados vigentes desde la antigüedad y aquellos reformulados por expediciones como las de Colón o Vespucio que desencadenó el paso por el estrecho de Magallanes, trajo consigo un replanteamiento espacial, pero también temporal.
Respecto a esto último, al completarse el mapamundi creemos que hubo un cambio en la forma en cómo comprender y relacionarse con el tiempo, algo que estuvo determinado por los nuevos espacios descubiertos. 


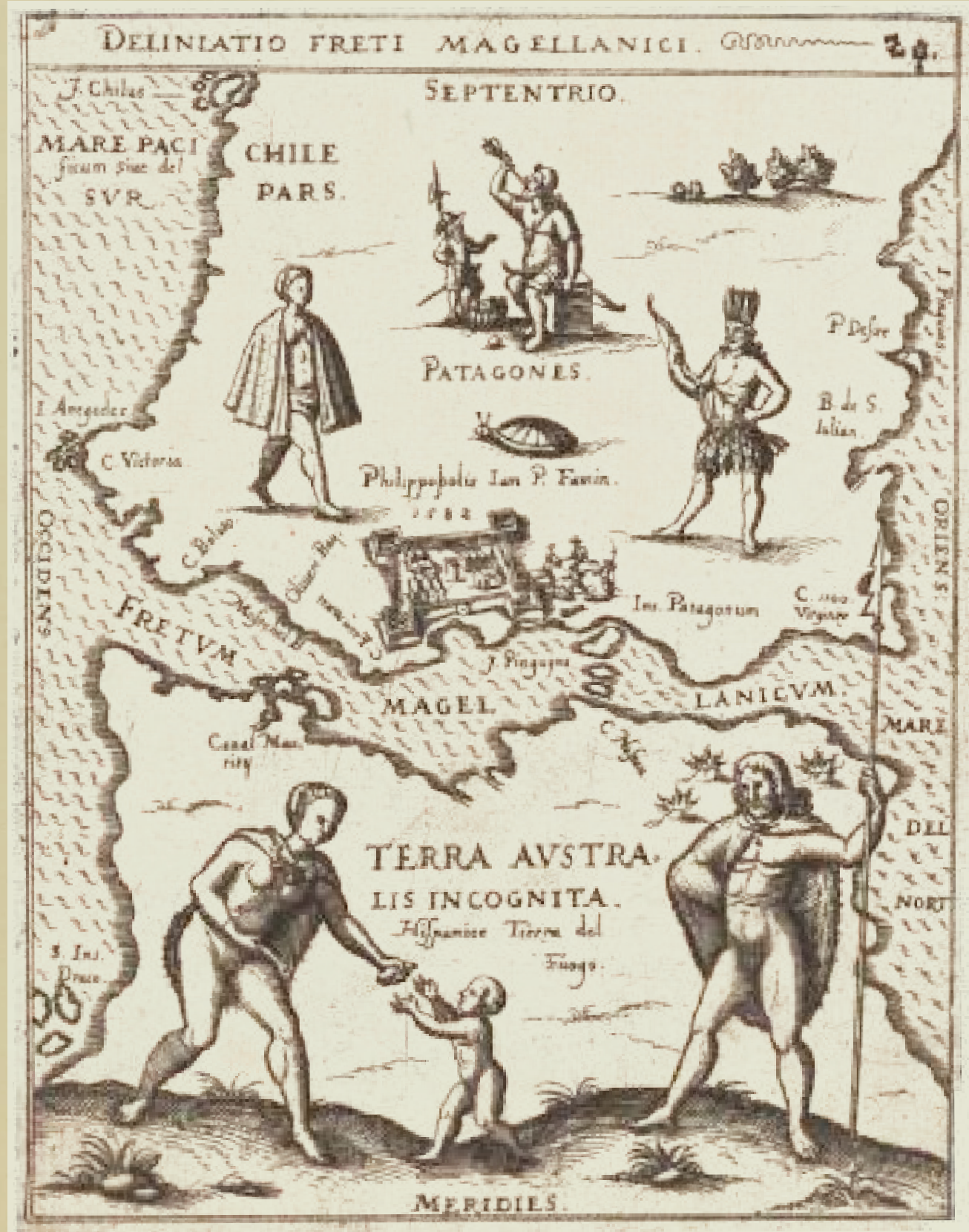

\section{Deliniatio Freti Magellanici}

Levinus Hulsius, Frankfurt am Main, 1626

Desde el punto de vista antropológico también se observan transformaciones tras el descubrimiento del Estrecho. La propia concepción de "humanidad", de lo humano, sufrió alteraciones. Las representaciones de los nativos de una serie de lugares se modificaron, en tanto, surgieron otras como lo fue el caso de los Patagones.

Las cartografías desde mediados del siglo XVI y hasta después del siglo XVII los presentan como personas con cualidades especiales -altura, fortaleza, etc.- tal como lo habían descrito las primeras narraciones de la expedición liderada por Magallanes. 
Así, pasado, presente y futuro adquirieron nuevas definiciones. Esto quedó de manifiesto de la siguiente manera: por un lado, lo aprendido del pasado se cuestionó; por otro, el presente extendió sus horizontes y la idea de transitar por el Nuevo Mundo descubierto se convirtió en la nueva referencia desde donde medir la realidad; y, por último, el futuro se consolidó como instancia de especulación e ilusión de encontrar riquezas y un mejor porvenir, en un "más allá" o "más adelante" que incluso podía ser utópico.

Un ejemplo de esta ruptura temporal fue que Transylvanus, en su carta, propuso reconsiderar ciertas verdades expuestas por los textos clásicos, ya que según él muchos contendrían información falsa. Para ello, dejó en claro que nombres como los de Plinio o Heródoto debían ser reemplazados por los de Pedro Mártir de Anglería o Hernán Cortés.

El mismo Transylvanus, para consolidar su importancia, narra ciertos sucesos vividos por estos personajes uno o dos años antes. Para él, la nueva historicidad necesariamente tendría que vincularse a la experiencia de circulación en el Nuevo Mundo develado, que era el territorio donde el presente y el futuro estaban en juego.
Así, sería la experiencia contemporánea, portadora de la verdad, la que permitiría acceder al nuevo paraíso. Y en el "más allá”, en lo incógnito, se encontraría el relato histórico a seguir.

\section{Nuevo Orbe, nuevos monstruos}

La ruptura espacial obligó a modificar y redefinir muchos de los significados de las imágenes que componían al mundo hasta la fecha. Dentro de esta serie de cambios de paradigma que hemos mencionado es que se instauró la Modernidad, caracterizada por la apertura temporal-espacial hacia lo nuevo en contraste con lo antiguo, y en la que, como define el filosofo Peter Sloterdijk, la conquista del mundo se efectúa a través y desde la imagen. Por ejemplo, es en este contexto que surge en la época la necesidad de revisar lo que hasta ese momento definía la imagen del otro, o alteridad. Al respecto, lo que hizo Transylvanus fue invertir el paradigma que regía hasta la expedición de Magallanes, pues consideró como "monstruosas" las propias empresas de conquista -y no a las culturas desconocidas, como se hacía hasta entonces-, quienes estaban dispuestos a poner en peligro sus vidas, a veces innecesariamente, con el fin de conseguir réditos. 
Haemisphaerium Stellatum Australe Cum

Aequali Sphaerarum Proportione

Andreas Cellarius

Amsterdam, 1708

Este cambio en la idea de quiénes

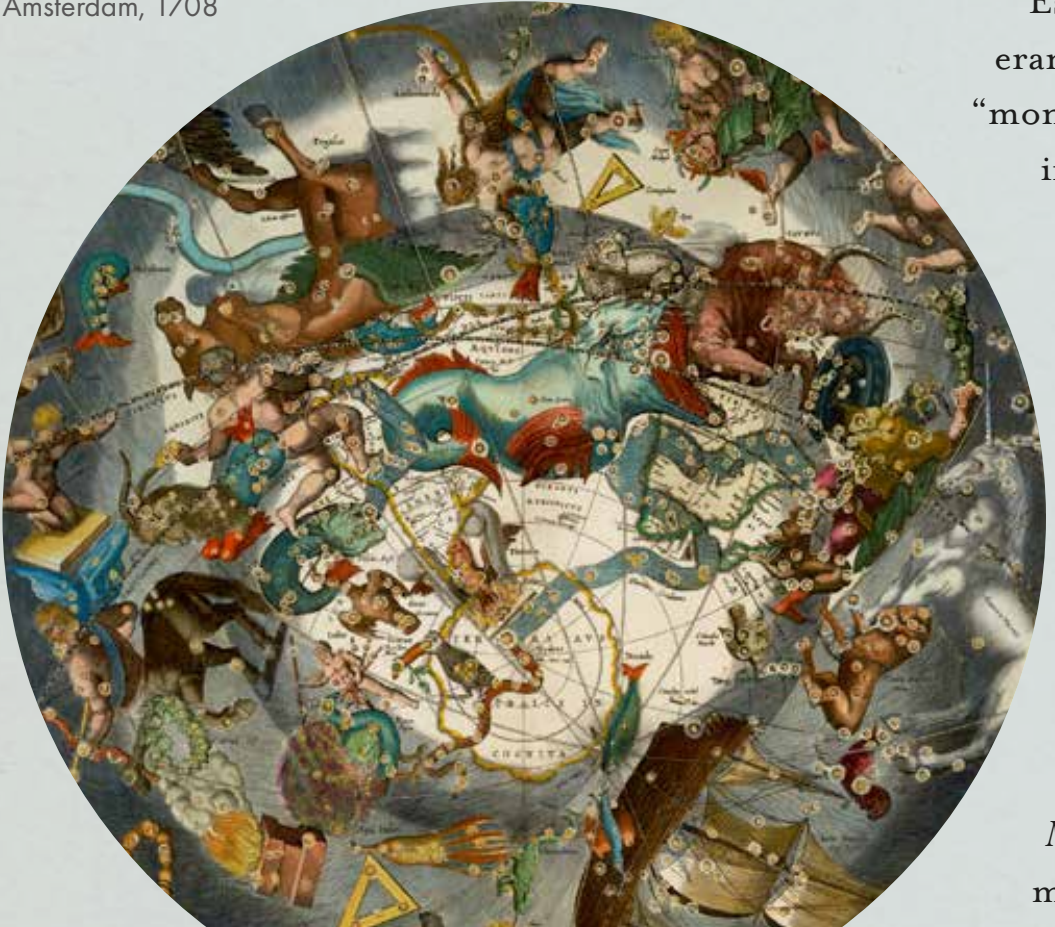

eran los verdaderos monstruos o de

"monstruosidad", relacionada con lo

inconmensurable del objetivo de

las empresas de conquista y con

el efecto que éstas produjeron,

estuvo directamente vinculado

con la nueva consciencia-mundo

en la medida en que, por un

lado, dicha idea se expresa a través de una diversidad de

formas no siempre estéticas ni coherentes que buscan expresar observaciones y experiencias sobre el Nuevo

Mundo y, por otro, se relaciona al movimiento ilimitado y sinérgico a nivel planetario que fue la tónica de una época en la que objetos y personas empezaron a conectarse en función de ambiciones personales y colectivas.

\section{Celestial Globes Gores Johann Schöner, Strasbourg, 1517}

El monstruo moderno es una imagen síntesis, resultado de una monstruosidad distinta, de la conciencia que se tuvo de la interacción con nuevos elementos, lugares y personas, y de la búsqueda de apropiación de todo ello en el contexto planetario. De hecho, a diferencia del monstruo de períodos anteriores, sobre el que se pensaba que había sido creado por Dios con fines punitivos y con características contranaturales -algo que quedó registrado decorativamente en múltiples cartografías-, observamos en el monstruo moderno que su existencia, desde el siglo XVI, se articula y relaciona íntimamente con las nuevas problemáticas que planteó el develamiento del estrecho de Magallanes: consciencia-mundo, circulación, ganancia, inversión y riesgo-catástrofe. 


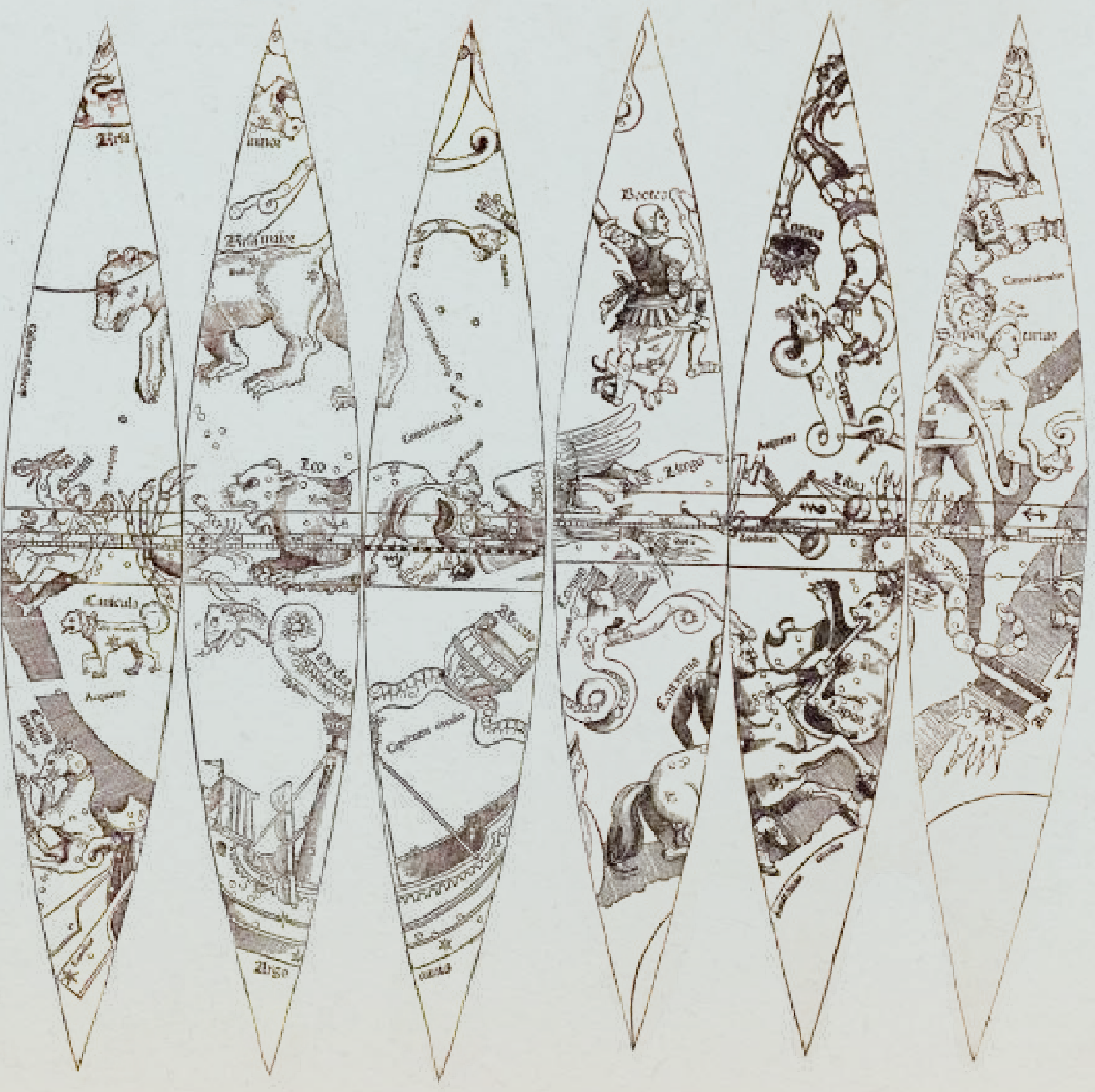




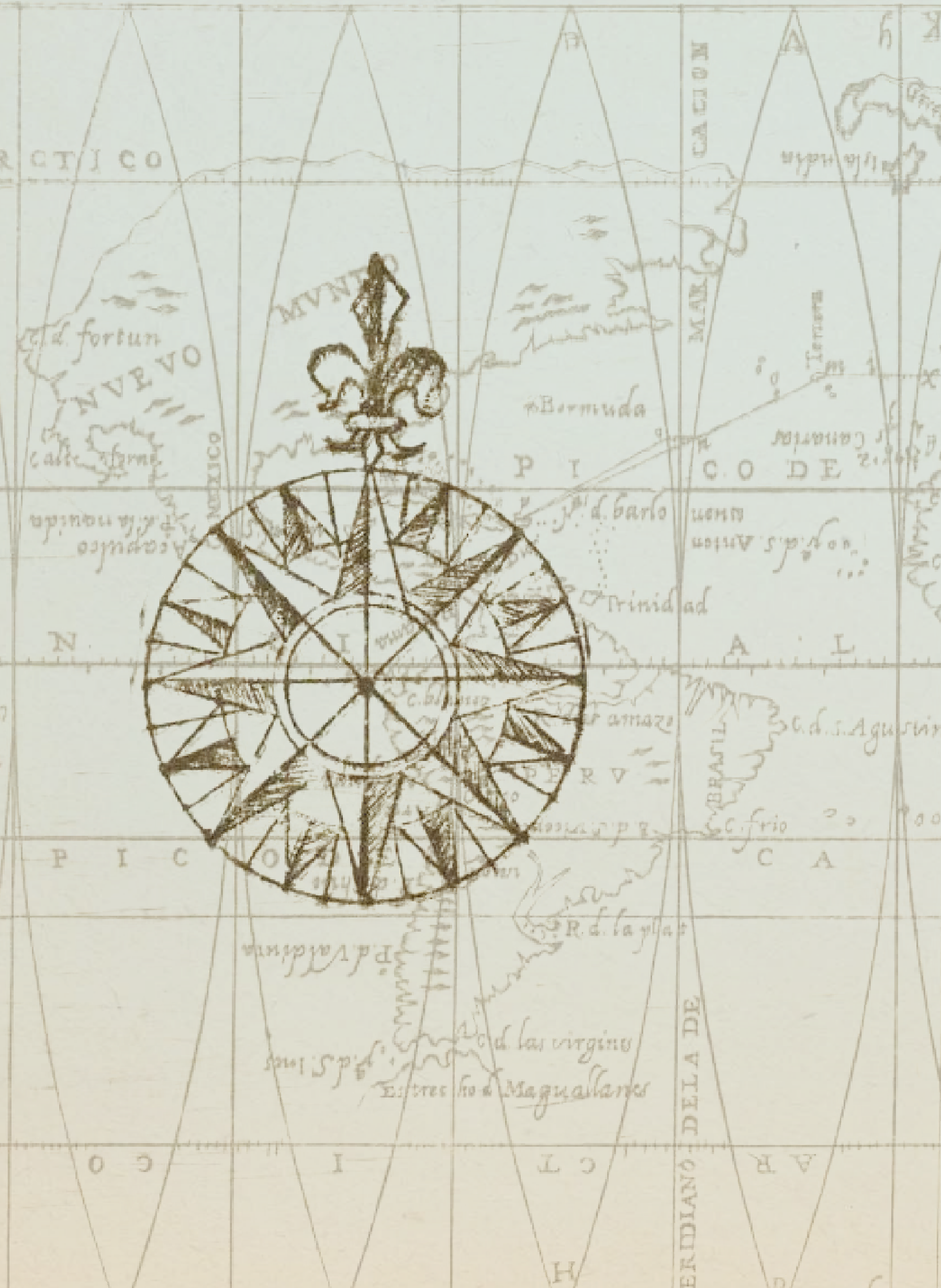





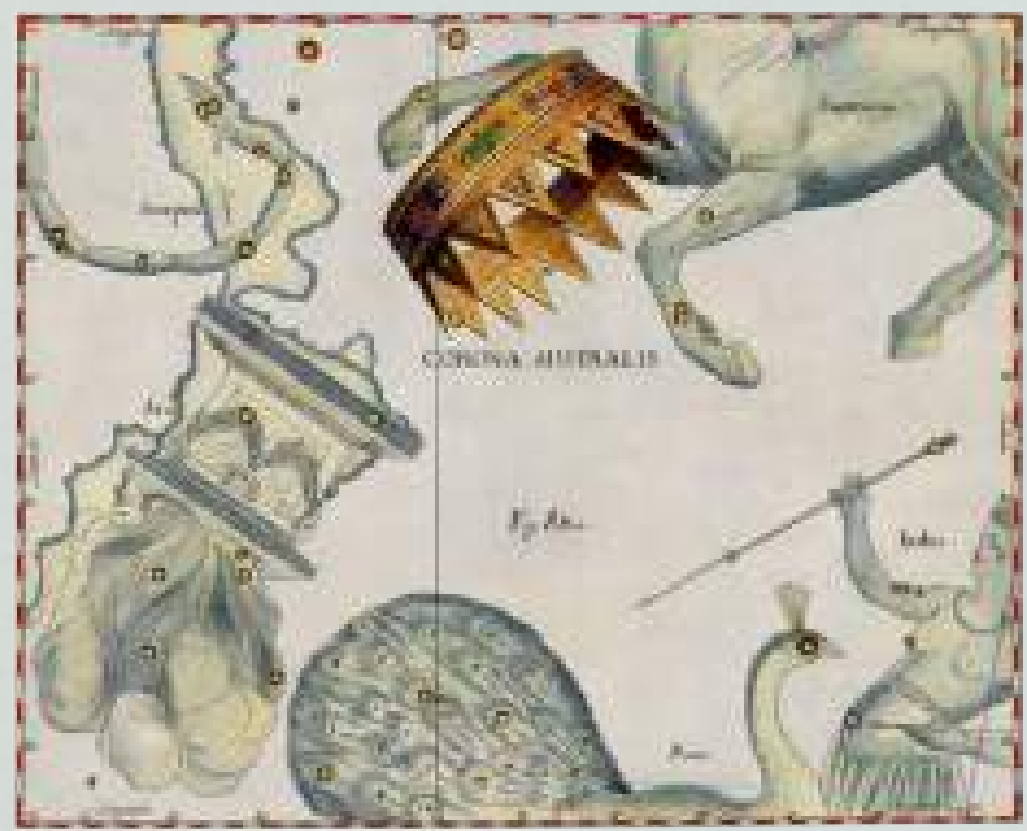

Prodromus Astronomia

Firmamentum Sobiescianum sive Uranographia table AAA: Corona Australis Johannes Hevelius Gdansk, 1690

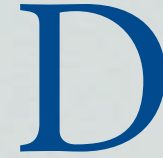
ESDE QUE FUE ATRAVESADO OFICIALMENTE EN I520, el estrecho de Magallanes se consolidó como un territorio de referencia que sirvió para crear y reconfigurar diversas territorialidades, tanto oceánicas como continentales.

Esto significó que, luego de la experiencia de su tránsito, debiéramos pensar no solo en una nueva Tierra inserta en una geopolítica que creó cartografías particulares, sino también en un nuevo mar - por primera vez se pensó en el océano Pacífico en su conjunto-y en un nuevo mapa sideral.

En otras palabras, desde aquellos años el Estrecho se podría decir que funcionó como un centro conector de elementos del mundo natural, geográfico y estelar. 


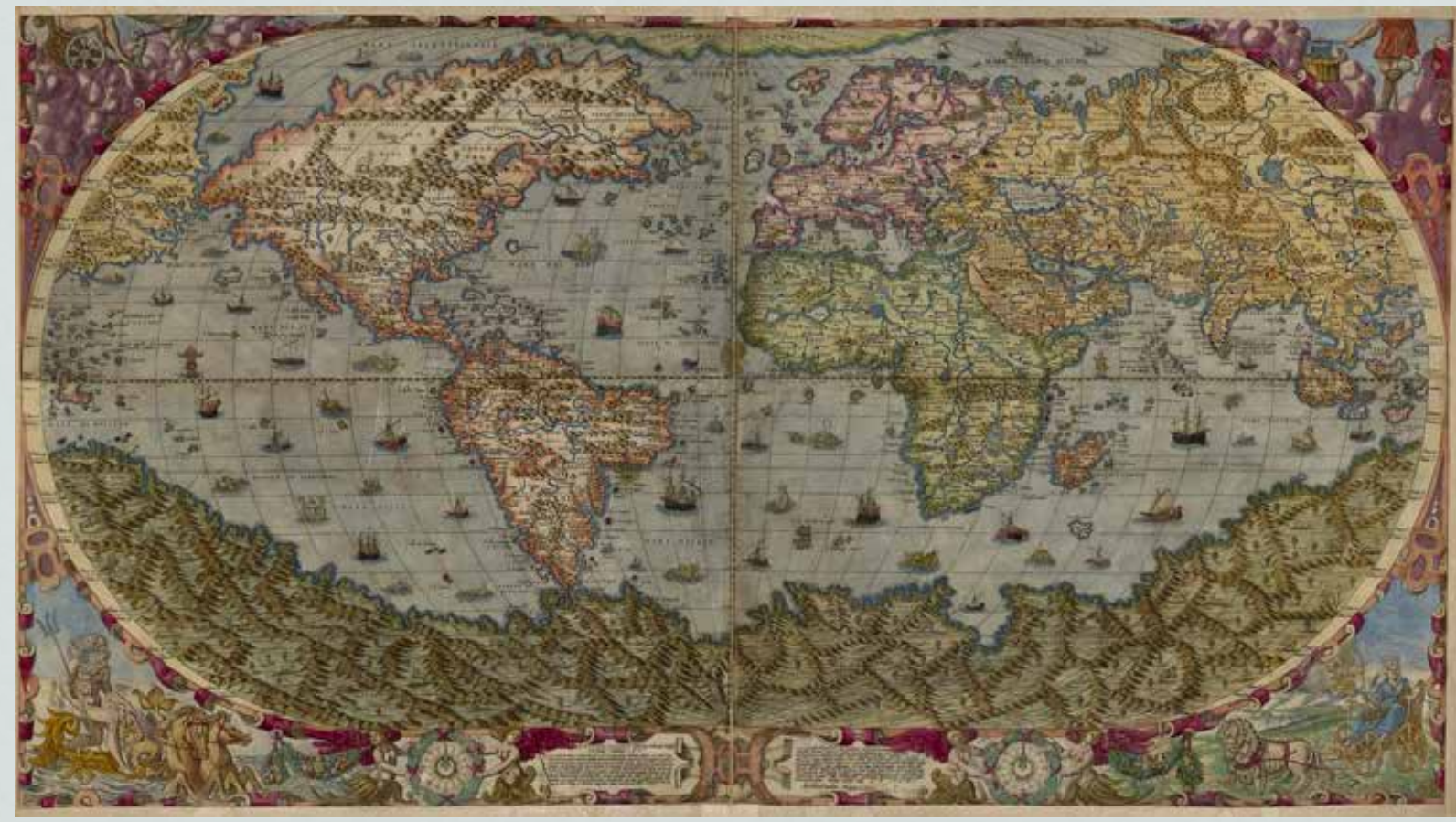

Mapamundi

Andrea Bertelli

\section{La aparición de lo Incógnito}

En términos cartográficos, durante las décadas posteriores a su descubrimiento el estrecho de Magallanes se utilizó como una puerta, delineador y límite de América, el Pacífico, el reino de Chile y sitios imaginarios como la Terra Australis. Con respecto a esta última, un ejemplo se puede ver en la Cosmografía Universal (I555), obra del francés Guillaume Le Testu, en la que el Estrecho se muestra como la puerta y el puente que permitía la existencia de esta tierra incógnita, salvaje pero fértil y de riquezas potenciales.

El trabajo del francés es revelador, además, porque en la secuencia que él presenta las escalas desaparecen y la Terra Australis se transforma en una proyección de América tanto en lo territorial como en lo relativo a la imaginería. Esto muestra una práctica que fue común en las cartografías de la época, las que fueron documentos que mezclaron tanto conocimientos de áreas diversas como también disposiciones estéticas de los territorios, a veces transitados y otras solo imaginados (Francia no tenía derechos ni siquiera a dibujar esta zona que pertenecía a la Monarquía Española).

En este sentido, se debe considerar que algunas territorialidades en la época eran más bien la imagen que se tenía del lugar, y sobre el que, en caso de no poseerlo, se especulaba. 


\section{Chare Cofmographique,aue les Nom, Propriens, Nacure \& Operations áes Vors}

Nordrordutite. Nowdug dith.

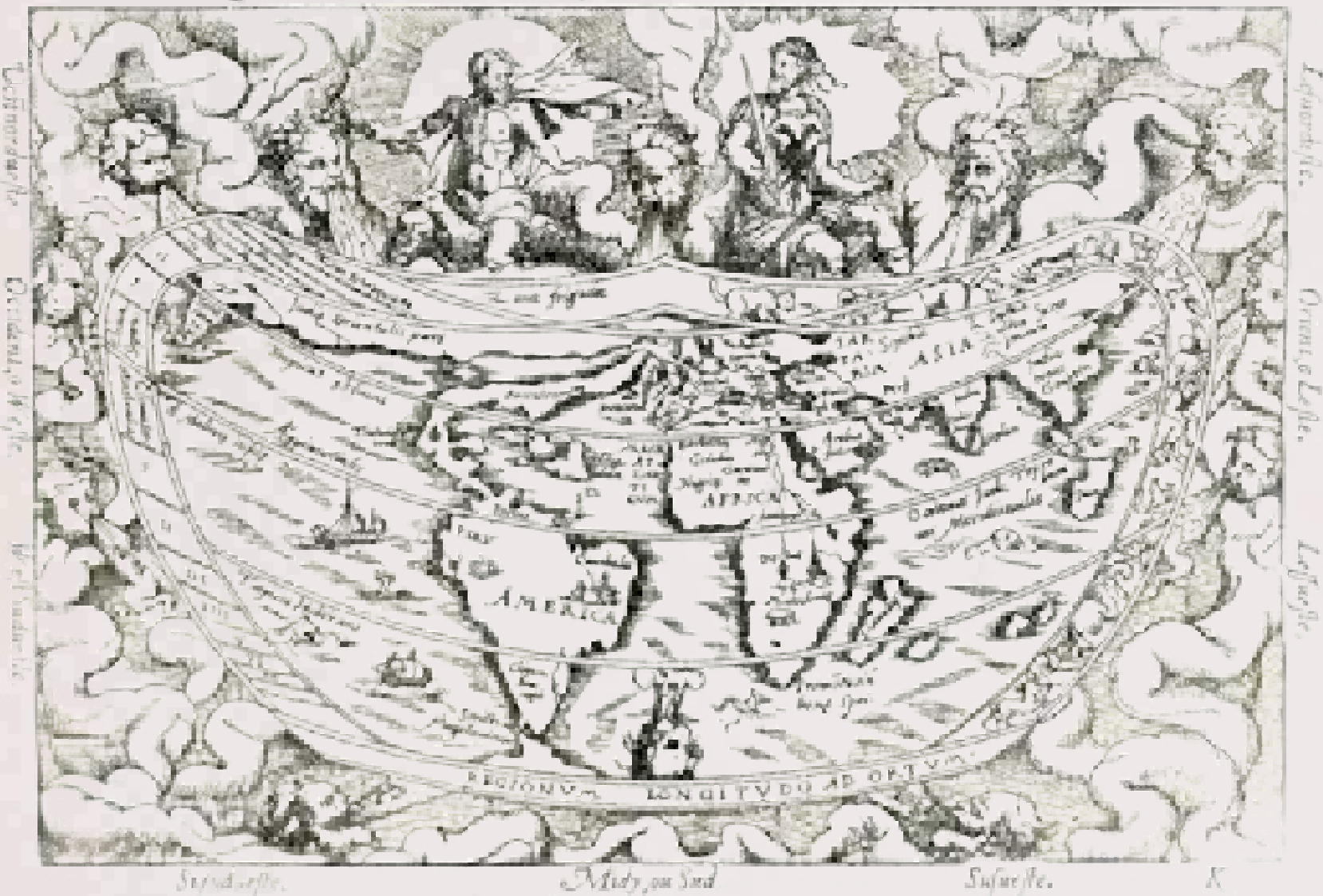

\section{Cosmografía Universal}

Petrus Apianus, Amberes, 1581

El estudioso Jean-Marc Besse define la cosmografía del siglo XVI como "la descripción que considera a la Tierra y el cielo como un todo: se trata de una operación intelectual que consiste en fabricar una representación de la Tierra considerando a esta desde el cielo, proyectando en la superficie de la Tierra las categorías y las divisiones de la astronomía". Asimismo, afirma que la cosmografía "es el espacio producido para el encuentro de los conocimientos descriptivos de la geografía y de los instrumentos de análisis dados por la retórica". 


\section{Un Nuevo Mundo desde el Estrecho}

Pensamos que el hallazgo del Estrecho, y no solo el descubrimiento de América, fue el acontecimiento que terminó por construir la idea territorial del Nuevo Mundo. Esto desde un punto de vista geopolítico, en relación a la conectividad de sus territorios con el resto del orbe y también respecto a la importancia simbólica de sus espacios.

Primero, interpretamos que es la propia América la que se habría completado a la espera de la confirmación de la existencia de un estrecho capaz de conectar de forma expedita las "cuatro partes del mundo". En efecto, una serie de actores de ese entonces -cartógrafos, marinos, matemáticos y políticos-, entre ellos el propio Magallanes, ya estaban al tanto de la existencia del Estrecho antes de su descubrimiento. Varias cartografías de la época en las que la parte sur de América, por el lado del Pacífico, ya aparece dibujada, atestiguan esto; y se aprecia con mayor claridad aún luego de la aparición de las cartas de Vespucio, mapamundis como el de Waldseemüller, en I507, o el Globo de Shönner en I5I5. No obstante, todas estas imágenes y creencias solo podían adquirir legitimidad luego de que una experiencia náutica las demostrara.

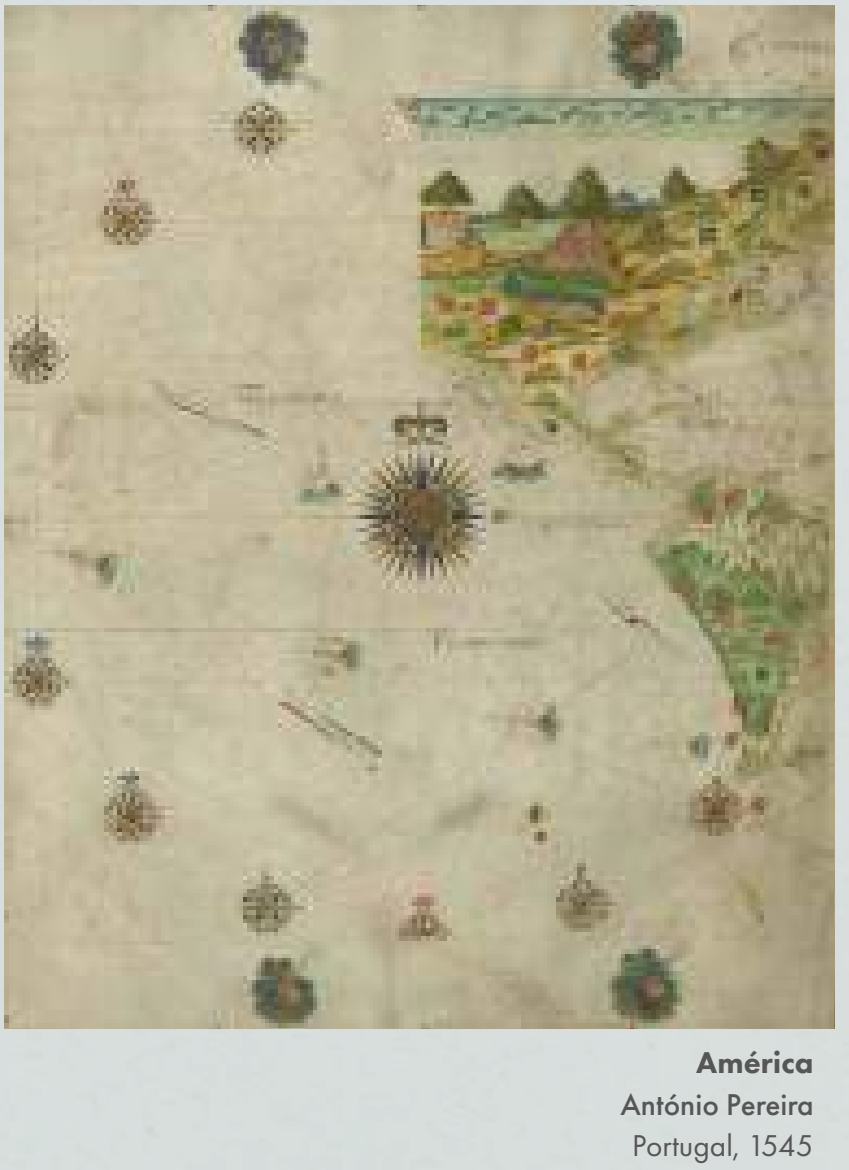

En cuanto a lo simbólico, el estrecho de Magallanes permitió alargar hasta el extremo sur de América las riquezas y los paisajes idílicos que se imaginaban en este continente. El "más allá”, dado por las tierras incógnitas que se esperaba encontrar después del Estrecho, extendieron los deseos iniciales de las potencias europeas y permitieron completar con contenido los territorios que se sabía que existían pero que no habían sido explorados. 

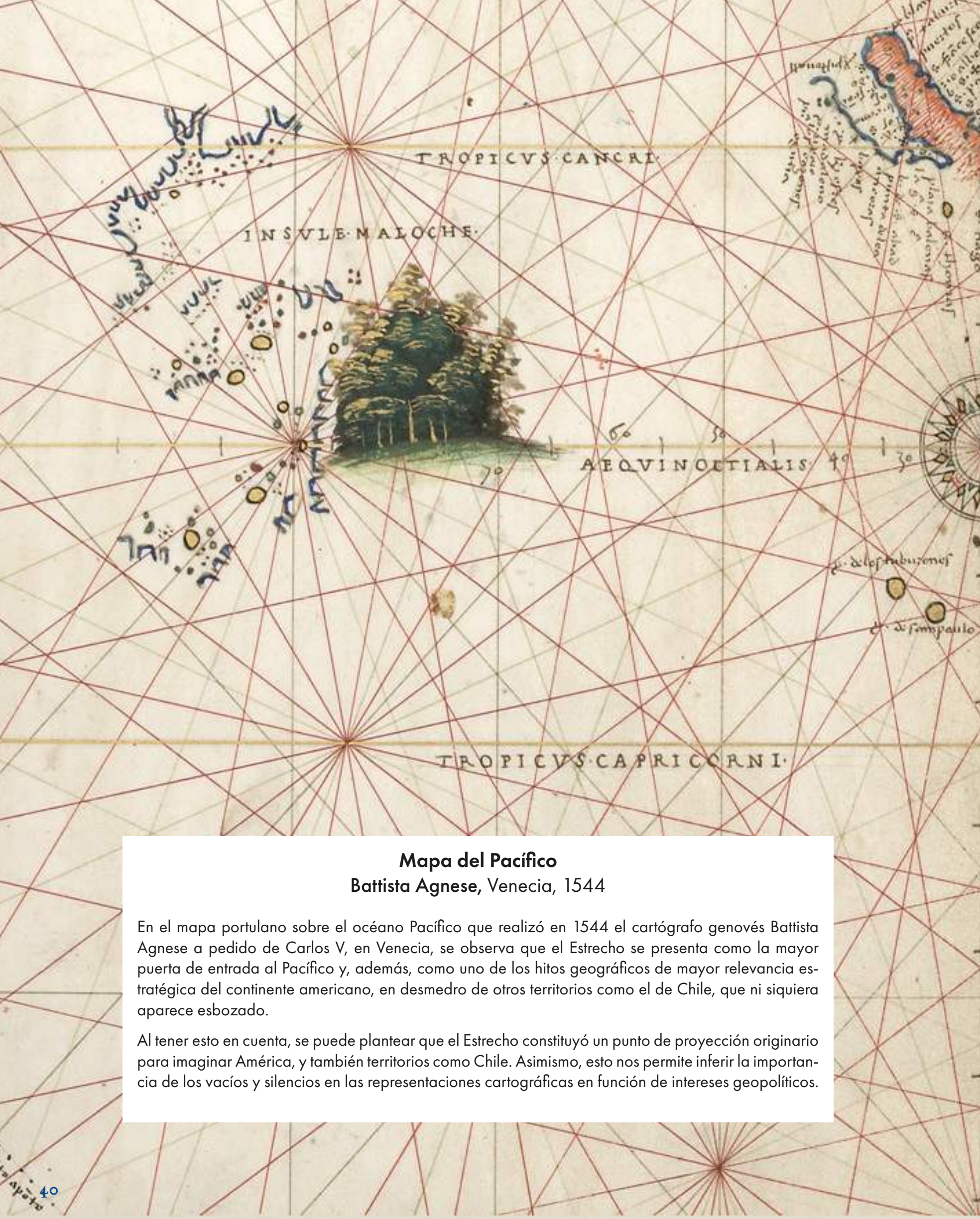


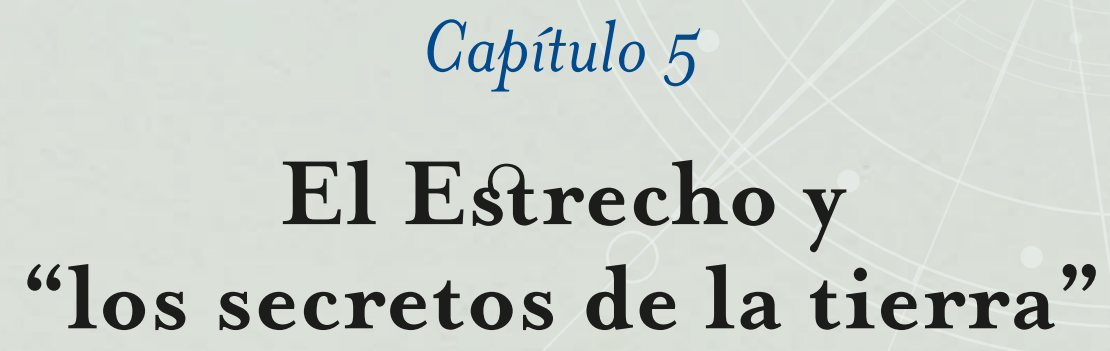




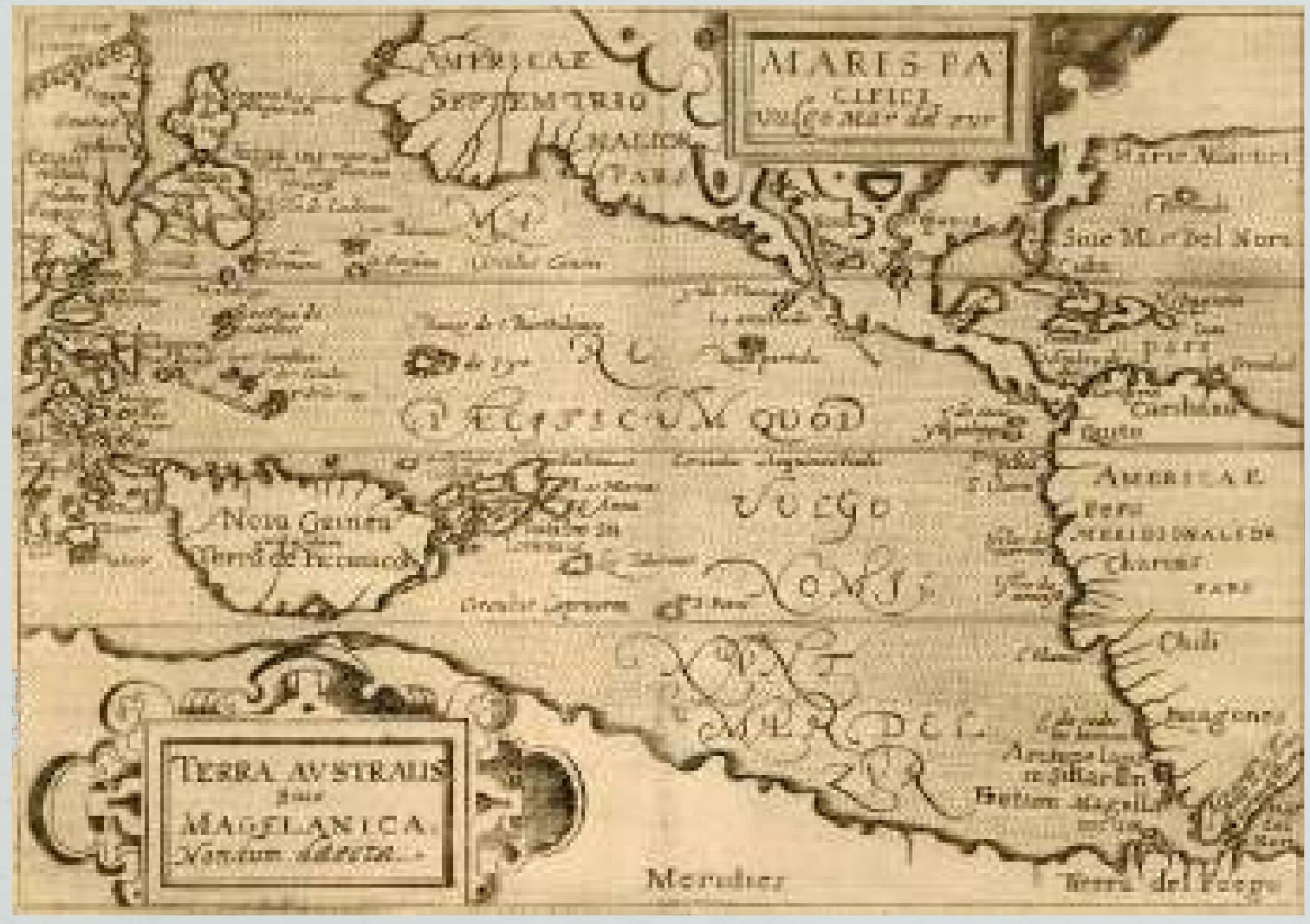

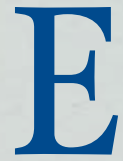

L DESEO DE POSEER EL

estrecho de Magallanes estuvo vinculado no solo a la idea de ir "más adelante", sino que también a la idea de secreto, la que se representó de diversas maneras. De hecho, como ya señalamos, la propia expedición de Magallanes fue portadora del "secreto a voces" que era la existencia de un paso por el sur de América que conectaba con Oriente. Esto nos sirve como ejemplo de la existencia de una serie de secretos de navegación que pudieron existir en la época, y también nos permite pensar en una puesta en escena del secreto como una forma de regular o catalizar las empresas de expansión comercial y de conquista.
Maris Pacifici vulgo Mar del Zur José de Acosta Colonia, 1598

Se puede afirmar que gracias al descubrimiento del Estrecho se terminó de instaurar desde los Estados europeos una geopolítica que dibujaba territorialidades del secreto, es decir, una política de Estado sobre cómo proceder en lugares asociados a secretos - de la tierra, riquezas, objetos poderosos, etc.que, a la vez, proyectaban un más allá o una dimensión de lo incógnito que se debía poseer y conquistar, y donde aún todo podía ser posible, especulado Así, el descubrimiento de ciertos lugares no solo tenía una evidente importancia económica -sobre todo por la especiería-, 
sino que también se relacionaba con el deseo ya instalado desde la época medieval de descubrir los "secretos de la tierra". La territorialidad del secreto fue la respuesta casi inmediata al cierre definitivo del mundo que provocó la confirmación de la existencia del Estrecho. Se dio por medio de la prolongación -respuestaimaginaria de un más allá que funcionaba como apertura, y que si bien tenía la posibilidad de posicionarse en un nuevo lugar cualquiera, con el tiempo quedó enfocado principalmente en la Terra Australis. Además, la territorialidad del secreto sirvió como reconocimiento de que el mundo se había cerrado y de que la circulación podía ser infinita a partir de una motivación intangible, inspirada en el valor de la transacción y del auge extremadamente rápido de la experiencia real de poder circular por el mundo. En otras palabras, "la territorialidad del secreto" fue un arma real que funcionó tanto discursiva como cartográficamente por medio de la especulación de espacios, con el fin de justificar empresas comerciales o de conquista. En palabras de Jean-Marc Besse, en ese momento "lo desconocido y lo conocido adquieren un valor ontológico y epistemológico equivalente."

\section{Map of the World}

Ephraim Pagitt, Londres, 1600

En 1558, Carlos V mediante una Real Cédula solicitaba al gobernador de Chile ir a explorar las tierras que se encontraban después Estrecho. Le importaba conocer los "secretos" que pudieran existir en la zona:

Nuestro gobernador de la provincia de Chile, ya sabéis cómo os hemos proveído de la dicha gobernación hasta el Estrecho de Magallanes y porque nos deseamos saber las tierras y poblaciones que hay de la otra parte del dicho Estrecho y entender los secretos que hay en aquella tierra, os mando que desde las dichas provincias de Chile enviéis algunos navíos a tomar noticia y relación de la calidad de aquella tierra...(Archivo General de Indias, PATRONATO,32, R.4).

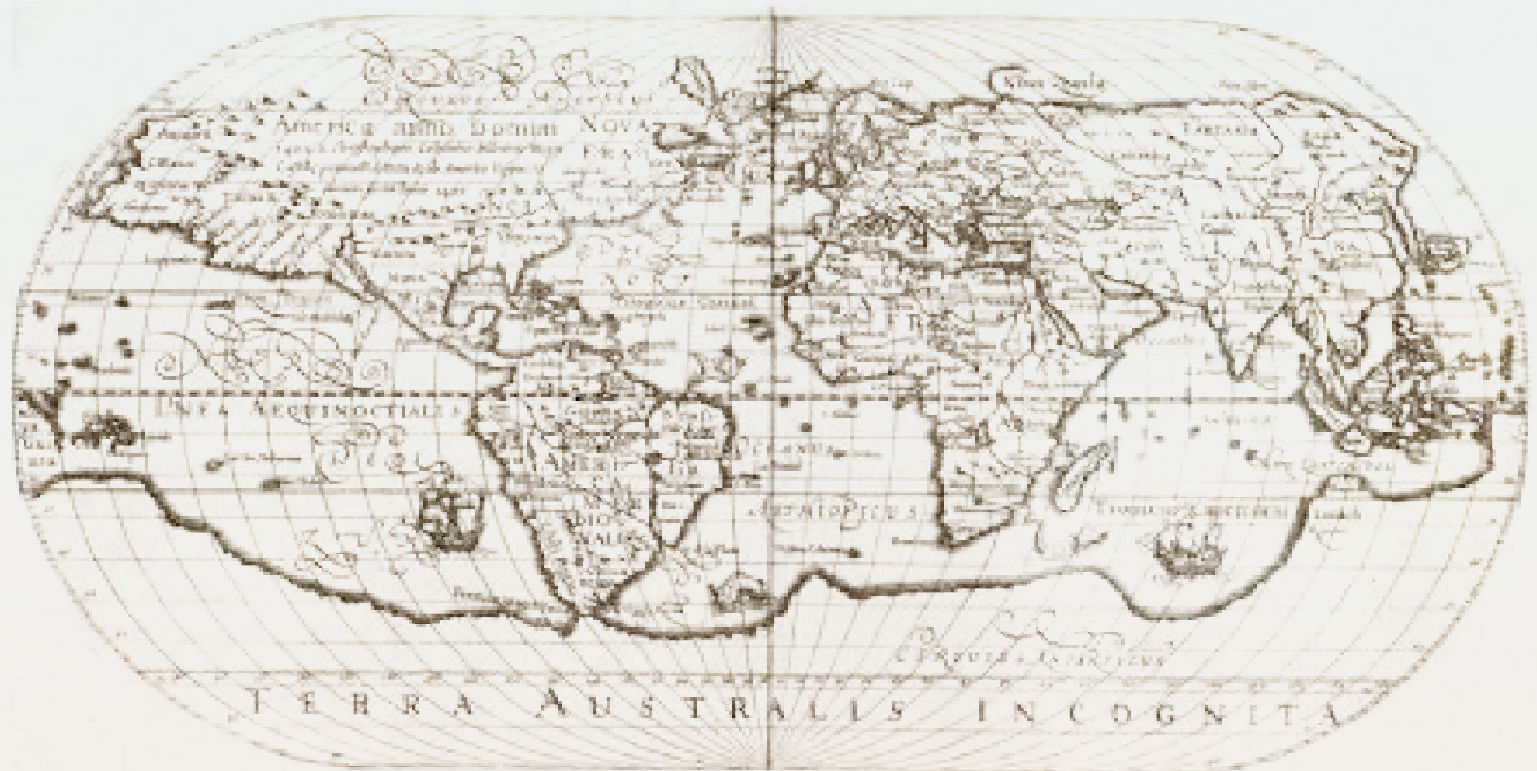



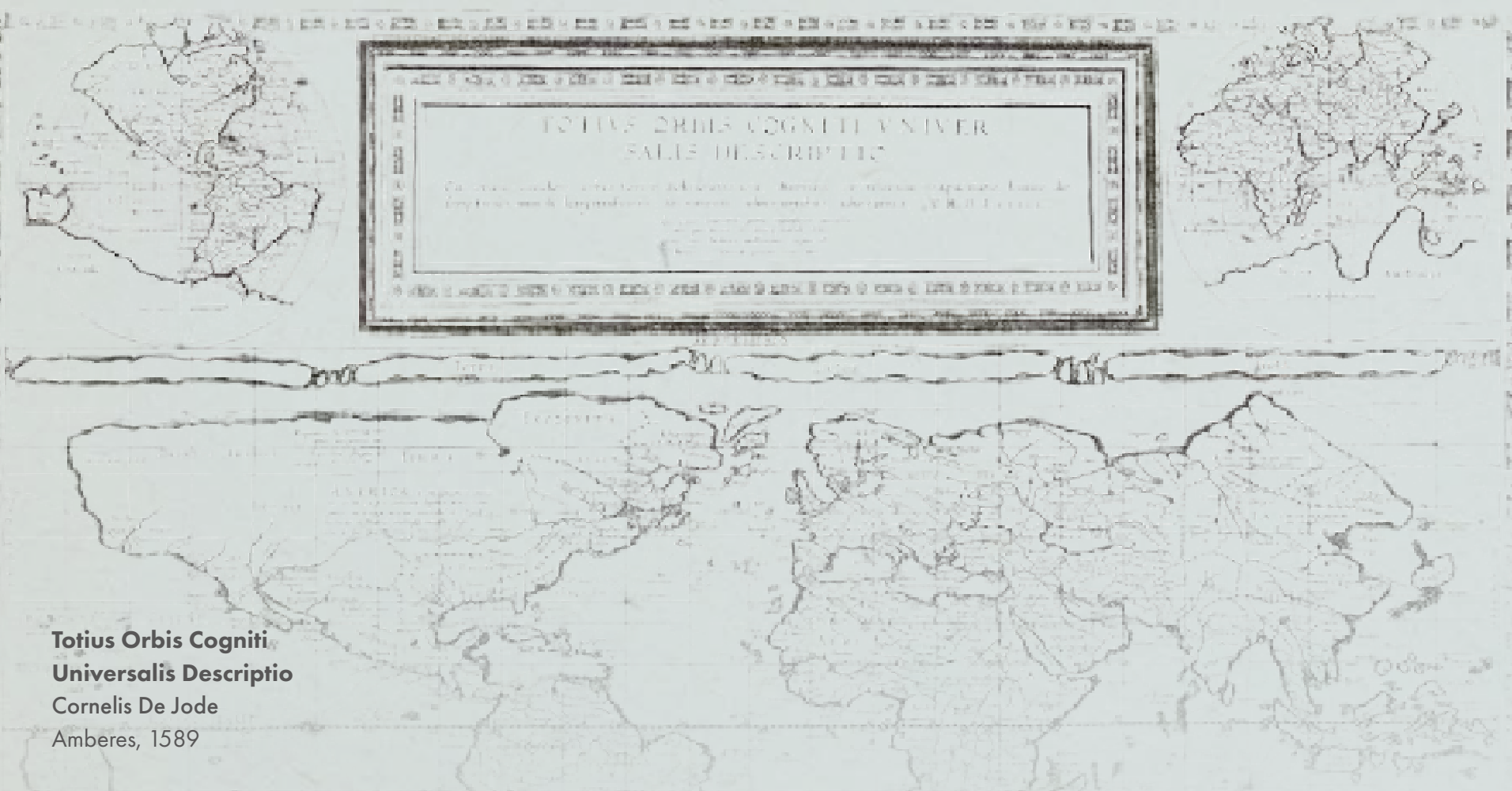

\section{Una motivación geopolítica basada en la especulación}

La búsqueda del secreto fue una forma de actuar geopolíticamente sobre todo en los territorios que aún no habían sido poseídos, en los que las historias de riqueza todavía no habían sido desmentidas y donde la especulación actuaba sin límite. En el caso del estrecho de Magallanes, este fue la puerta del más allá y también una territorialidad depositaria de secretos. Esta disposición se prolongó a lo largo del siglo XVI, en parte por la construcción de mitos e imaginarios en torno a ciudades de oro, como la Ciudad de los Césares o el traslado de El Dorado hacia la zona austral, y también por decisiones políticas propias de las empresas de conquista, como en el caso de Pedro de Valdivia.
Por otro lado, no solo la Monarquía Española se interesó por los "secretos de la tierra". Ingleses, Holandeses y Franceses también lo hicieron enviando expediciones al sur de América desde I530 en adelante. En varios casos expresaron aquel deseo por medio de cartografías, con las que intentaban justificar que el conocimiento de las zonas representadas les daba también derecho a aspirar a dichos territorios. Por ello, no es extraño que el trabajo cosmográfico de Guillaume Le Testu buscara establecer una "Francia Antártica", con el fin de poseer las riquezas que se esperaban de aquellas tierras. Con sus dibujos buscaba legitimar por medio de un conocimiento de la zona el derecho a conquistarla. 


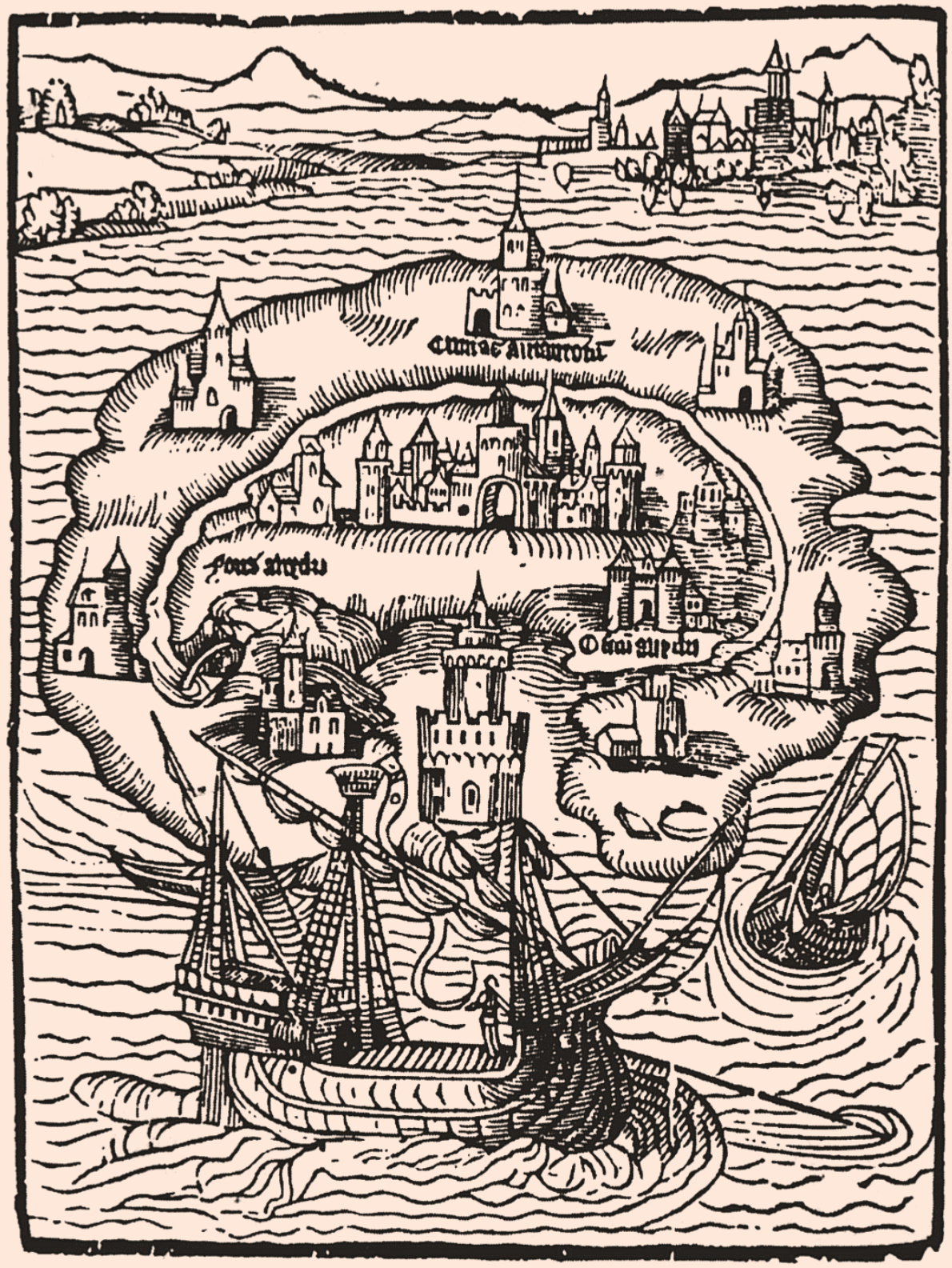

\section{Ilustración de la isla de Utopía en su primera versión de 1516}

Tomás Moro, político e intelectual inglés, publicó en 1516, en Lovaina, Bélgica, La Utopía, su obra más conocida. En ella, se relata el desarrollo idílico de una sociedad en la que el trabajo, la vida social, la religión y la moral funcionan en perfecta armonía.

Ya que Moro conocía las cartas de Vespucio y las noticias sobre el Nuevo Mundo, el tránsito por las tierras al sur del Ecuador que narra en el texto y ciertas coincidencias geográficas entre Utopía y la Isla grande de Tierra del Fuego nos hacen creer que existe una relación directa entre lo descrito en la obra y dicho territorio. Del mismo modo, planteamos que La Utopía le dio historicidad e inteligibilidad previa a la travesía del estrecho de Magallanes al plantear la necesidad de ir a un no-lugar; $y$, a su vez, el Estrecho le otorgó, a posteriori, una espacialidad concreta a la obra de Moro al revelar un territorio en un más allá desconocido hasta entonces. 
M. 0

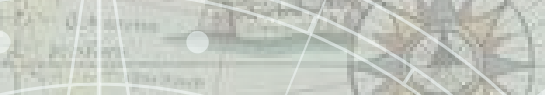




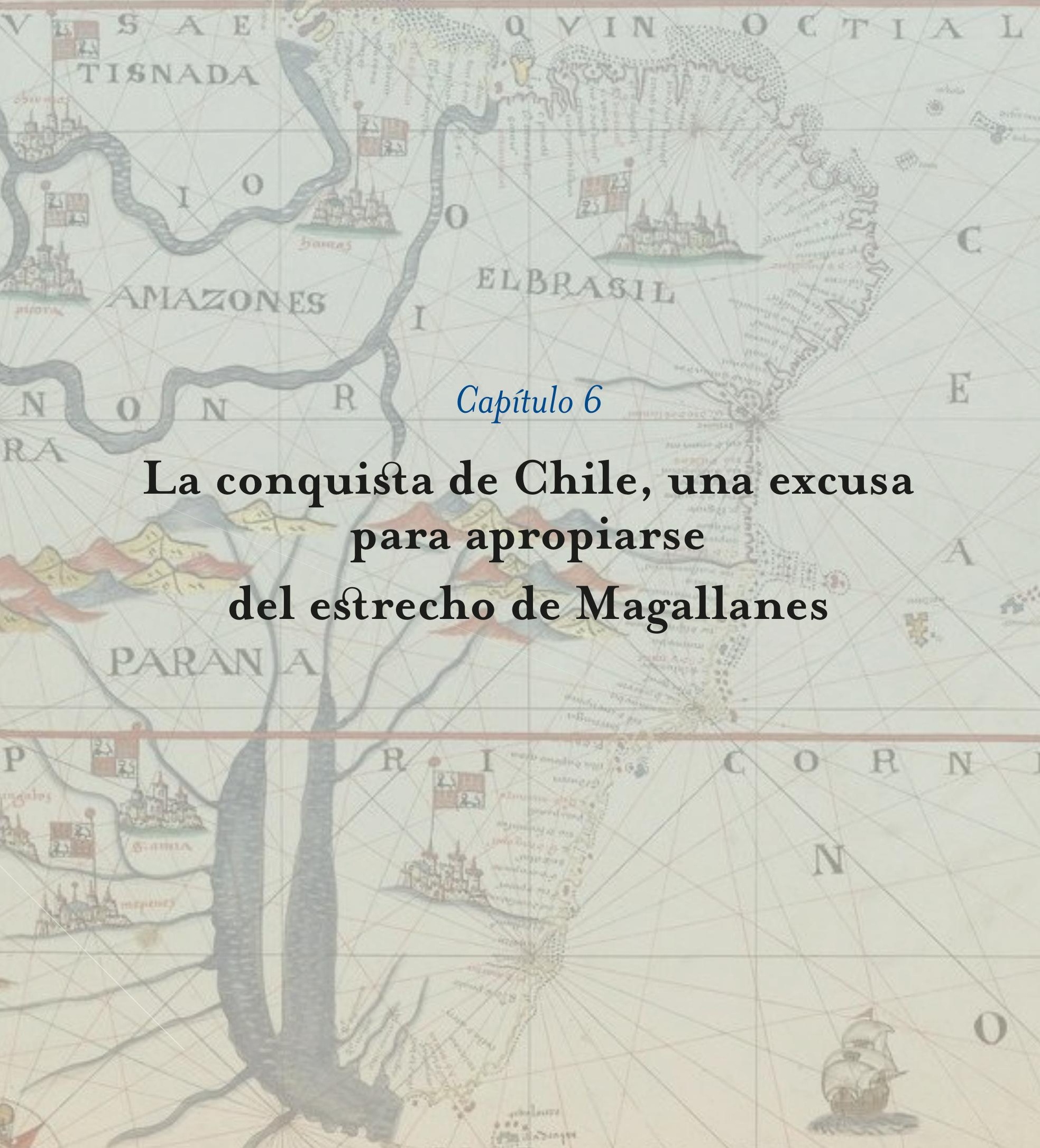


$\mathrm{P}$ ARA CONQUISTAR Y

CONTROLAR, durante el movimiento por el mundo. El propio Carlos V así lo practicó desde que fue nombrado emperador en I5I5. Nunca tuvo un centro fijo desde donde gobernar y por eso se dice que su monarquía fue más bien "ambulante".

Así, se puede decir que él mismo ejemplificó su lema plus ultra, es decir, siempre ir más allá.

En este caso, más allá de donde se pensaba que debía estar el centro de su poder.
En ese entonces, circular por el mundo no era asunto solo de emperadores, sino que los viajes eran empresas -siempre grupales- llevadas a cabo por privados, las que eran asociadas con dinero y futuros prometedores. Es en estas donde se insertan los conquistadores de América, como Hernán Cortés, Francisco Pizarro, Diego de Almagro, entre otros.

Como todas estas empresas partían desde Europa, era relevante para los reyes europeos obtener territorios que sirvieran de puntos de partida y de pausa desde donde se pudieran comenzar nuevas expediciones y adquirir mayores riquezas. $\mathrm{Al}$ ser dichas expediciones comandadas por los ibéricos las protagonistas de la circulación por el globo, al menos los primeros cincuenta años del siglo XVI, fueron regiones como Andalucía, los puertos italianos y flamencos y ciudades como Sevilla las que sobresalieron y funcionaron como plataformas de paso para ir a otros lugares del planeta.

Pedro de Valdivia, gobernador de Chile Juan Bautista Verdussen Amberes, 1728 


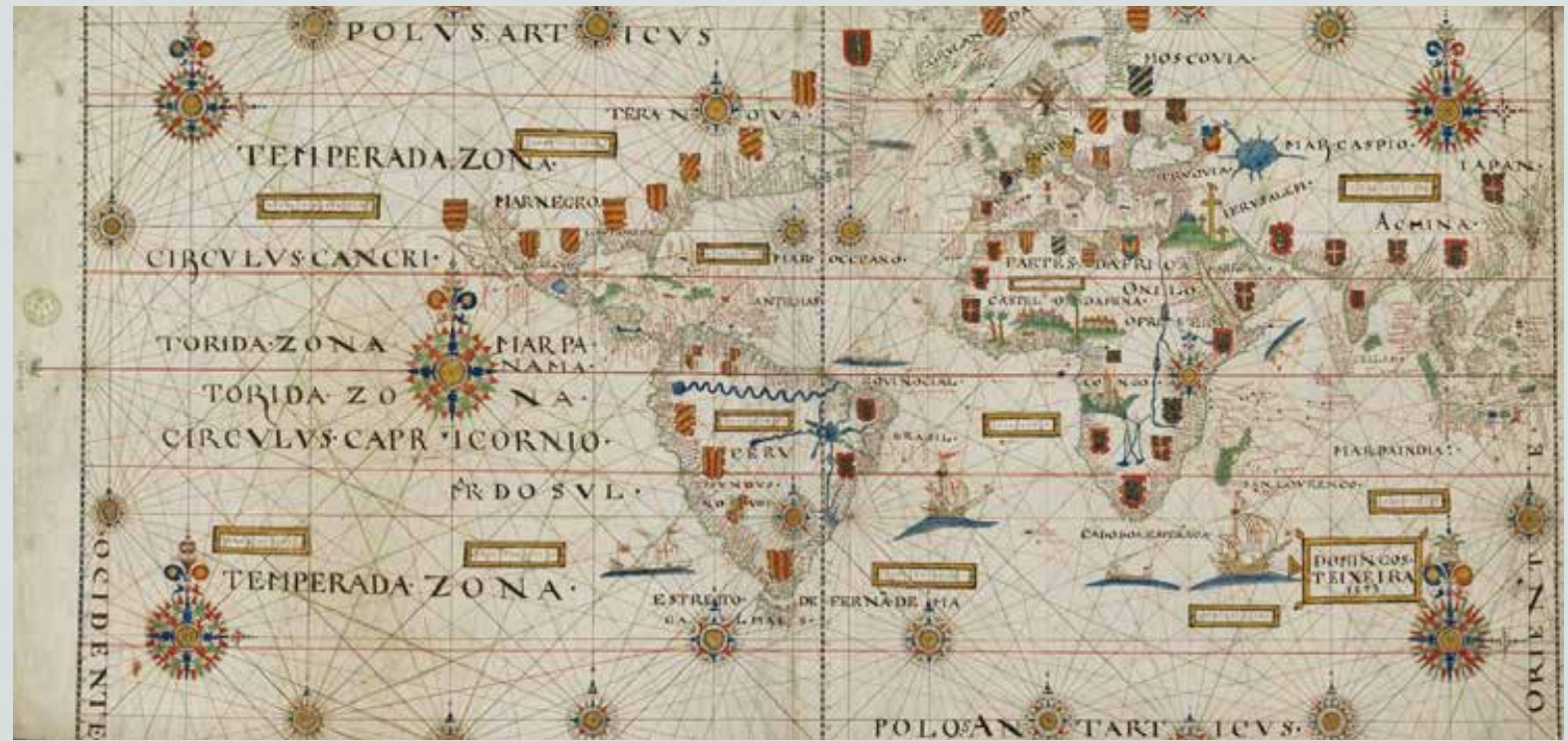

Portulano del Mundo

Teixeira Domingos

\section{Un nuevo extremo del mundo}

Uno de los hombres que tuvo claro el panorama geopolítico y que aplicó también para sí el lema plus ultra fue el soldado, primer gobernador y capitán General de Ghile Pedro de Valdivia, quien buscó incesantemente hasta el día de su muerte tomar el control del estrecho de Magallanes, puesto que sabía que este control le daría una posición diferente del resto de conquistadores. De hecho, distinto a lo que se puede suponer, su objetivo real no fue la ocupación y colonización de lo que hoy conocemos como la tierra de Ghile, sino que esta solo fue parte de un itinerario destinado a llegar al mencionado pasajemundo. Es el mismo militar quien lo dice en una de sus numerosas cartas al emperador, en donde afirma que
Santiago del Nuevo Extremo es tan solo el primer paso que permitirá poblar la tierra hasta el Mar del Norte y el estrecho de Magallanes.

Para el conquistador, el territorio de lo que se conocía como Chile era visto tan solo como un pasaje -estrecho- para llegar al gran pasaje. De esta forma, las ciudades de Chile, surgidas del itinerario propuesto antes de la llegada al territorio, habría que entenderlas solo como las pausas de un trayecto. Parafraseando al historiador Pierre Chaunu, en aquel tiempo Chile era una colonia que no puede entenderse si no es por el deseo de ir hacia el Estrecho, deseo que Pedro de Valdivia dejó de ocultar recién estando camino a Ghile, al solicitar, en $\mathrm{I} 550$, tanto el permiso para ir allá como su derecho jurídico. 


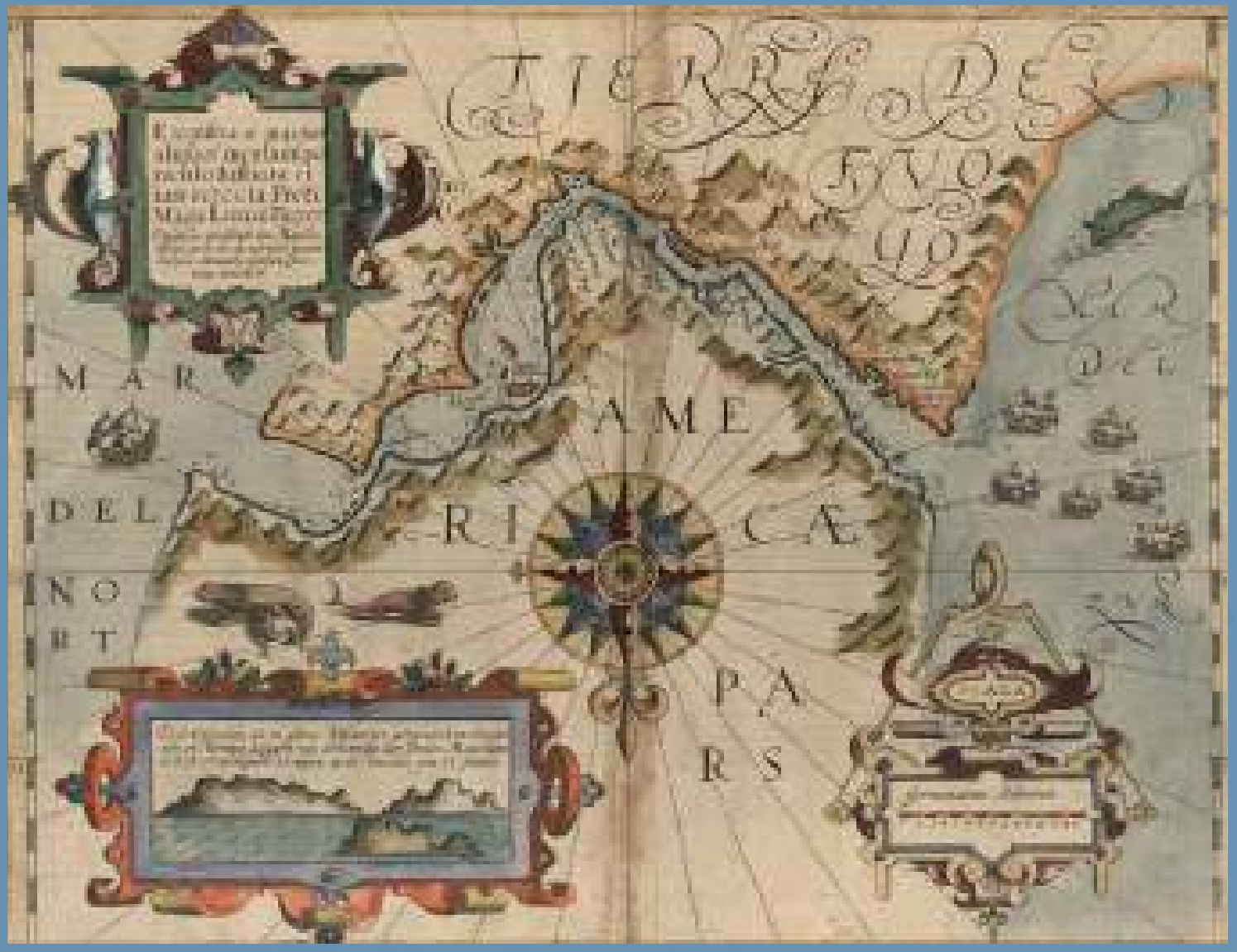

\section{Exquisita \& magno aliquot mensium periculo lustrata et iam retecta Freti Magellanici facies : eijgentlicke asbeeldinghe der Magellanischer Strate die nu met veel gevaers eitelijeke Maenden doorsien van nieus ondecktis Jodocus Hondius, Amsterdam, 1611}

En una carta en 1552 dirigida al príncipe Maximiliano (Felipe II), el fundador de Chile Pedro de Valdivia manifestaba las tres razones de por qué había que apropiarse del Estrecho :

"... es en que se navegue el Estrecho de Magallanes, por tres causas, dejadas las demás que se podían dar. La primera, porque toda esta tierra y Mar del Sur la tendrá Vuestra Alteza en España y ninguno se atreverá a hacer cosa que no deba; la segunda, que se tendrá muy a la mano toda la contratación de la especería, y la tercera, porque se podrá descubrir e poblar es otra parte del Estrecho que, según estoy informado, es tierra muy bien poblada". 
Entonces, dejó en claro que le interesaba la "perpetuación de la tierra", dado que así podría hacer inteligible y útil este lugar que para el resto del orbe aún era un espacio virtual -potencial-, aún susceptible de existir.

\section{Controlar "lo de adelante"}

Desde otra perspectiva, se puede afirmar que Pedro de Valdivia comprendió políticamente los flujos e intereses que en la época se desarrollaban en las distintas partes del orbe. $\mathrm{Su}$ llegada a América en I535, tardía en comparación con otros conquistadores más reconocidos, ayuda a comprender su verdadera motivación. Él supo leer el momento propicio para intentar crear una de las empresas más ambiciosas de la época: conquistar y controlar el Estrecho, lugar que funcionaría como nuevo límite del mundo y desde donde esperaba situar un nuevo centro de poder que tuviera el control para ir a ese "más allá", entendido en un principio como Oriente, pero que posteriormente podía ser lo que se conoció como Terra Incognita.

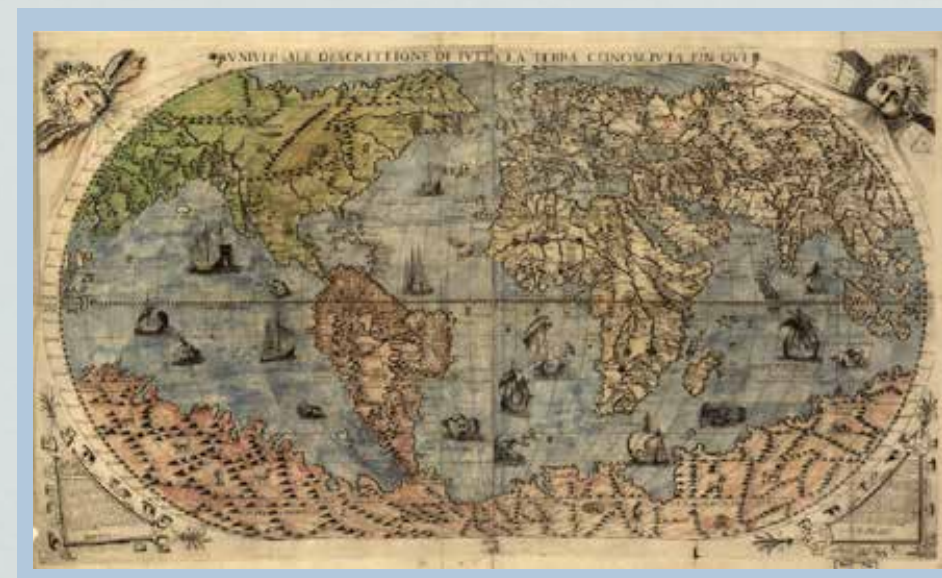

Universale descrittione di tvtta la terra conoscivta fin qvi

Fernando Berteli Venecia, 1565

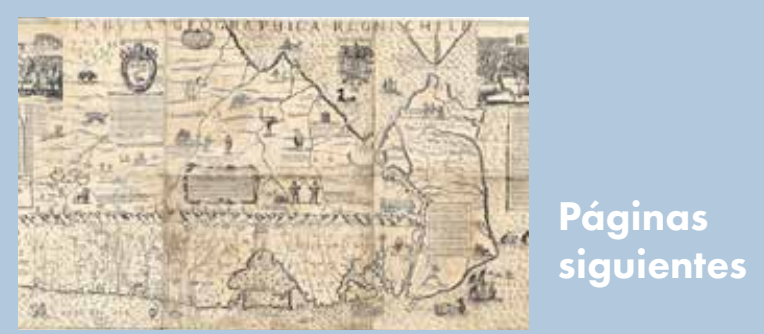

\section{Tabula Geographica Regni Chile}

en Alonso de Ovalle, Histórica relación del Reyno de Chile y de las missiones y ministerios que exercita en el la Compañía de Jesus Roma, 1646

En el siglo XVII, ante la imposibilidad de acceder por tierra al Estrecho y posicionarse en la zona, se produjo un cambio respecto a la concepción del "Plus Ultra" que inspiraba dicha parte de América entre algunas autoridades de Chile. Por ejemplo, el Jesuita Alonso de Ovalle, en su célebre libro Histórica relación del Reyno de Chile y de las missiones y ministerios que exercita en el la Compañía de Jesus, proponía una idea inversa para entender a todo este territorio: "Porque como aquel Reyno [Chile] está tan remoto, y apartado, y viene a ser lo último de la América, ninguno va a él, para pasar a otra parte, porque aquella del Sur viene a ser el non plus ultra del mundo". 


\section{RAPHROA R E GNNCH I LE}
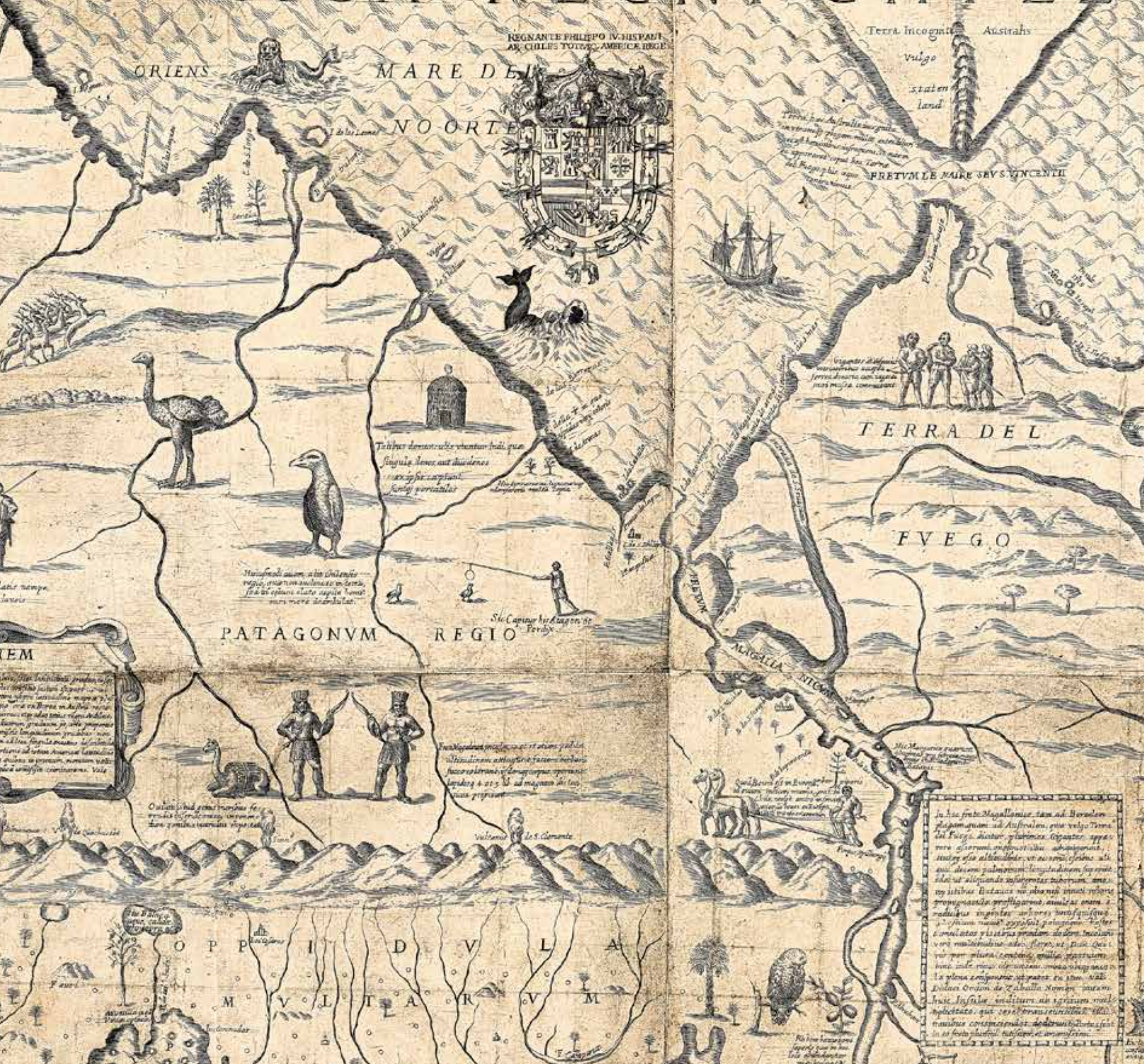

ind $5=2$ ?
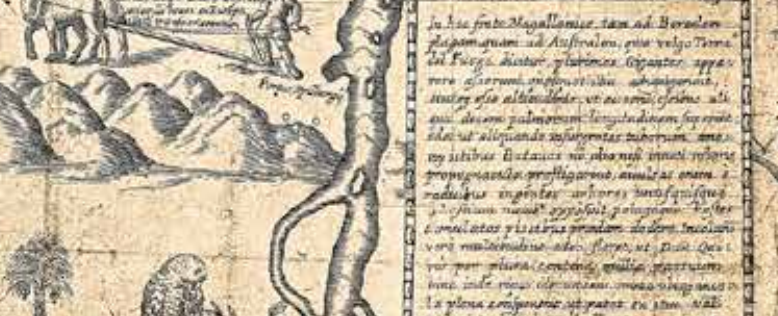
A

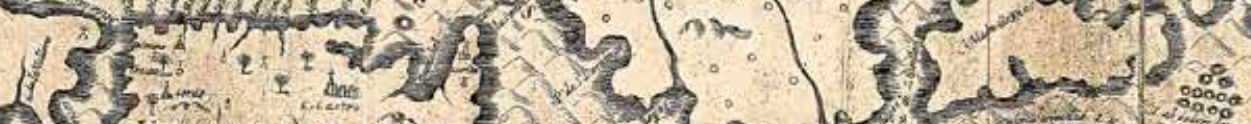
arizentis 320

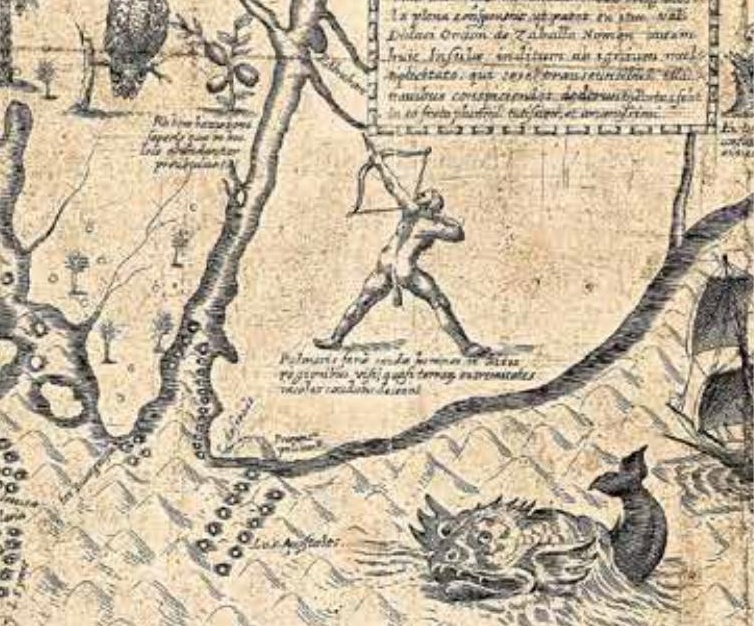

$20 \%$ ? N 


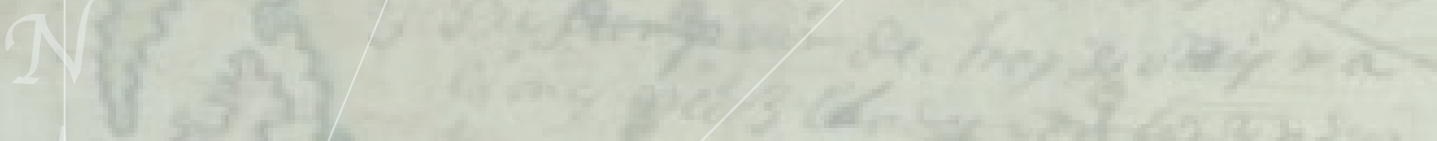

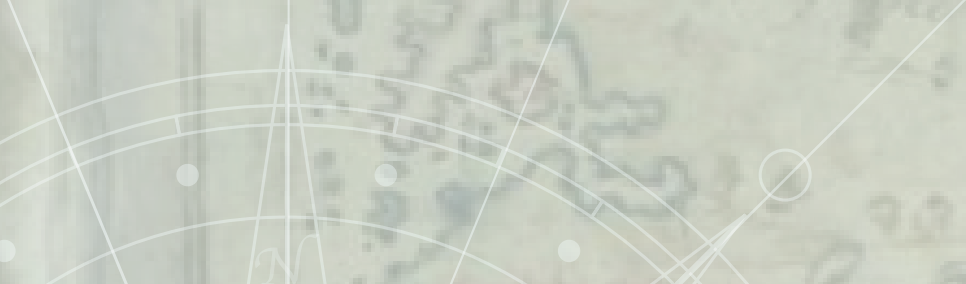

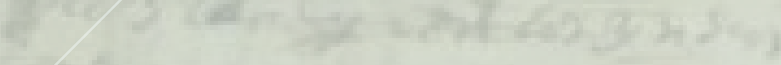

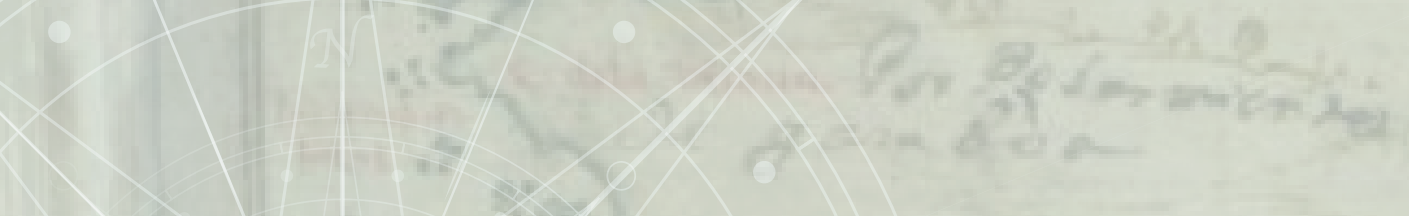

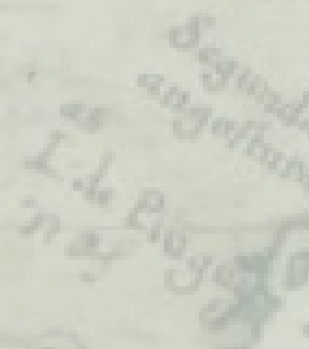
$+1$

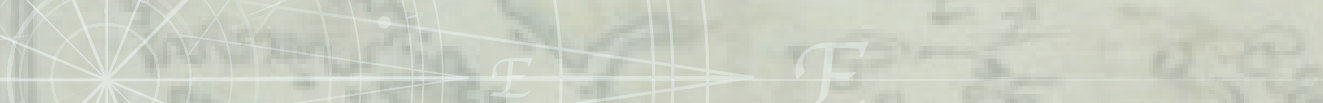
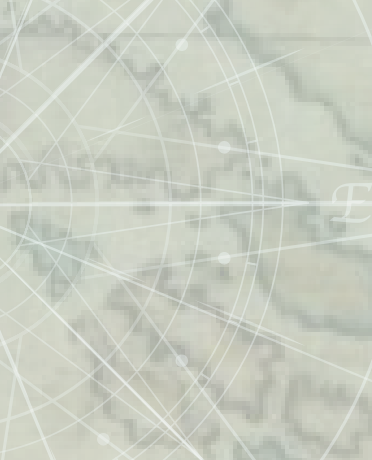

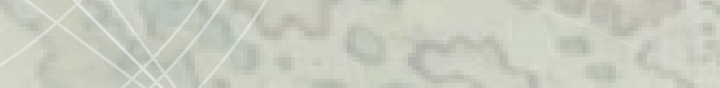

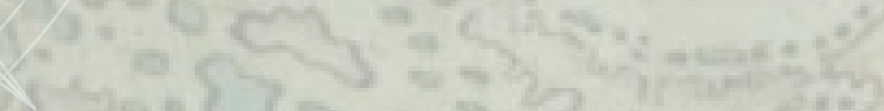
Q

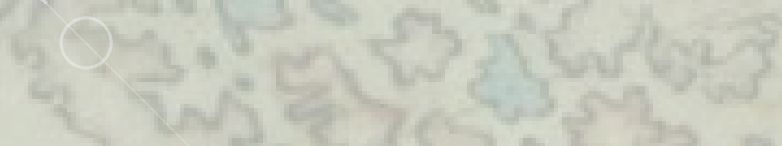

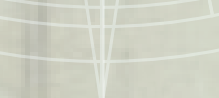

(1)

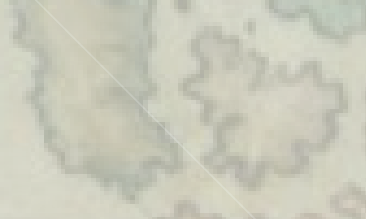


Capítulo 7

\section{Los primeros conocimientos sobre el estrecho de Magallanes: naufragios y exploraciones de observación}





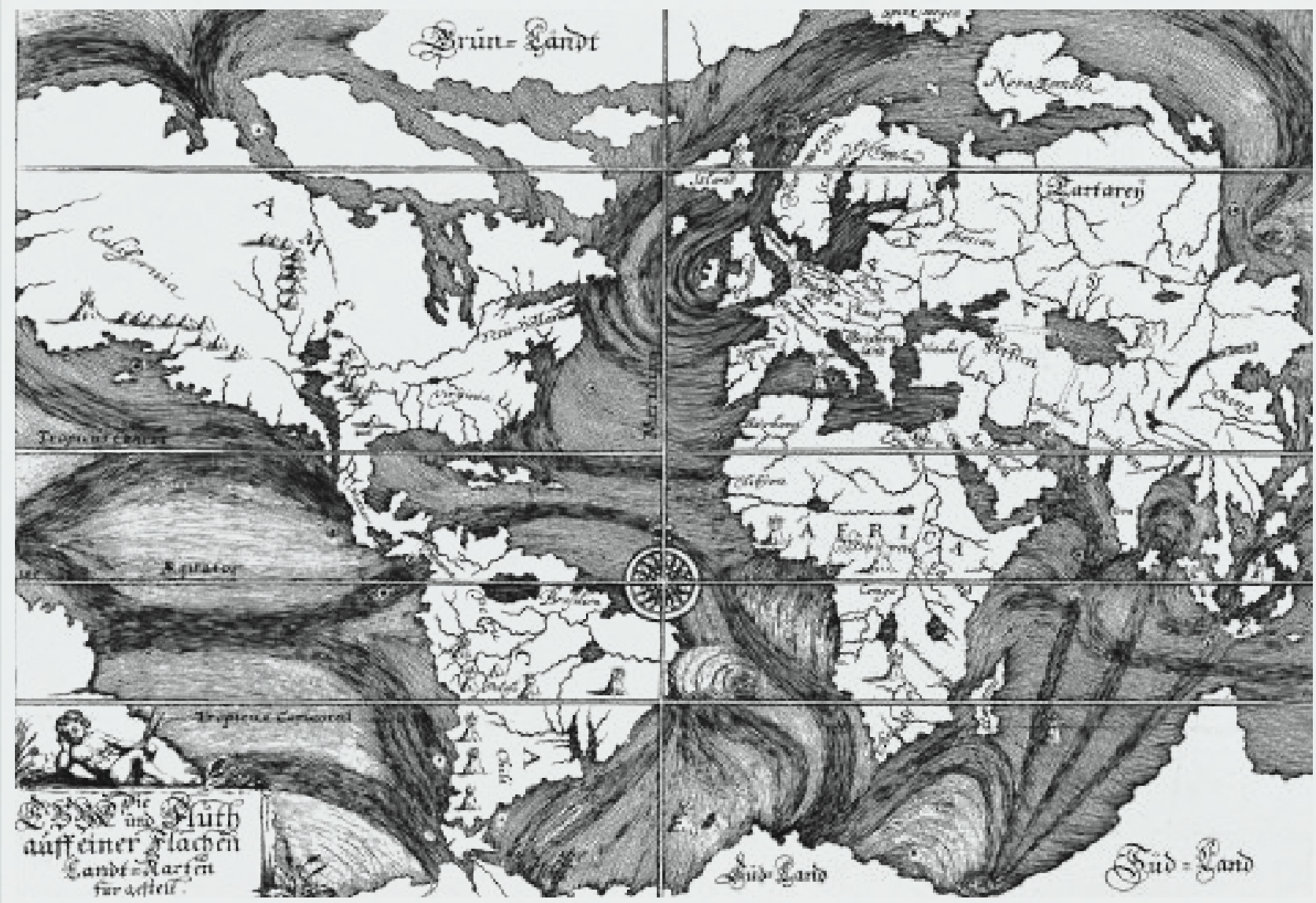

Ebbe und die Flüth auff einer Flachen Landt-Karten fürgestelt Eberhard Werner Happell Ulm, 1687

Lo largo del viaje y lo complejo que era navegar en la zona austral de América hicieron que la mayoría de las expediciones que se autorizaron tuvieran problemas, muchas veces fatídicos. Fueron pocas las que se aventuraron, debido a la gran cantidad de medios que se requerían para ir y por la presión que hubo de parte de los conquistadores que se encontraban en el norte de América, a quienes no les gustaba la idea de que se pudiera pasar a las Indias por otra parte que no fuera la actual Panamá.
En las dos décadas que siguieron

al "descubrimiento" tenemos las excursiones de Francisco García Jofré de Loayza (I525-I526), quien iba con Juan Sebastián Elcano, de Simón de Alcazaba (I535), de León Pancaldo (I538) y de Francisco Camargo (I54O), todas expediciones que vistas desde la perspectiva del asentamiento y de la pérdida de hombres y medios se pueden considerar un fracaso. 


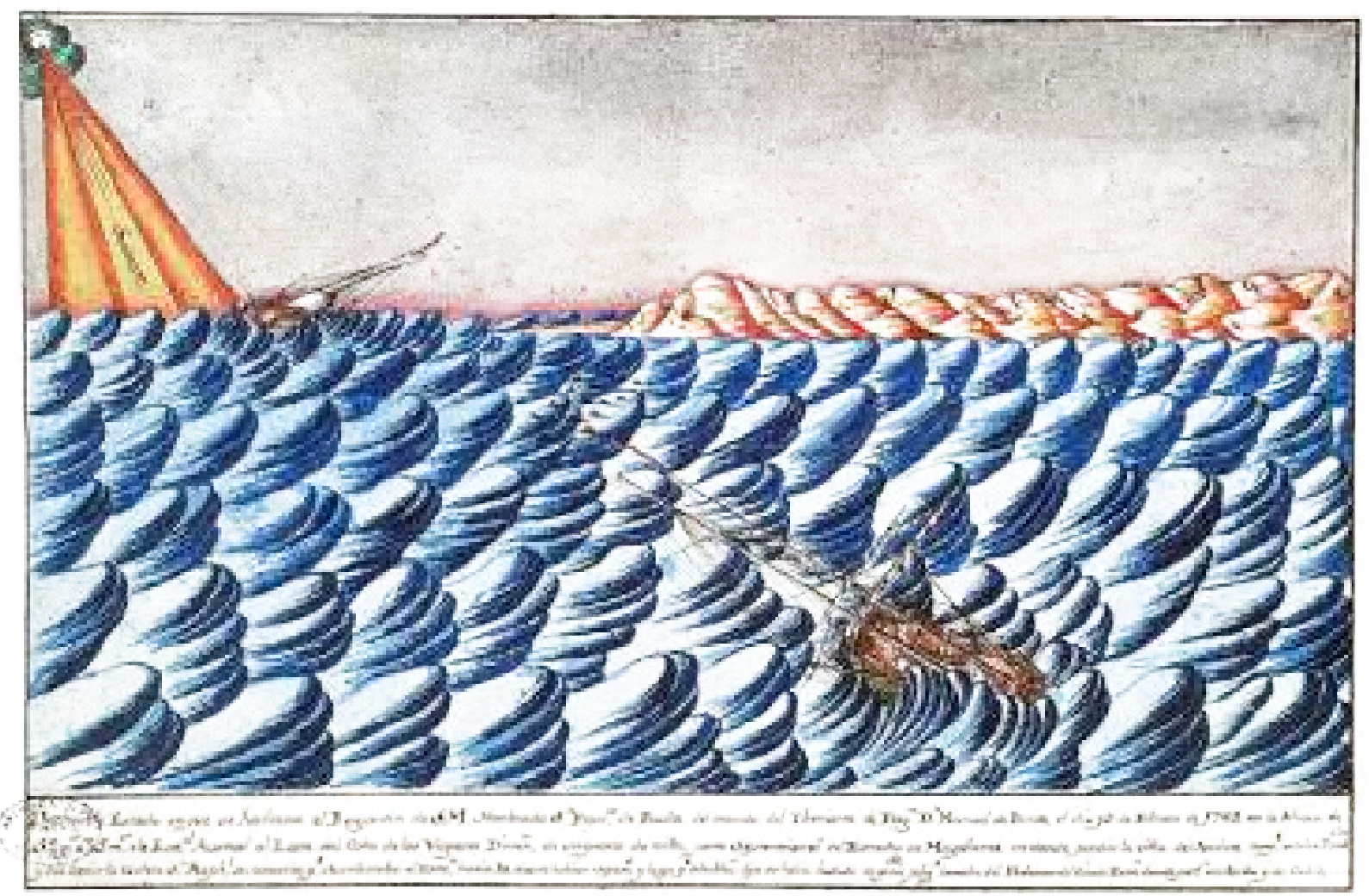

\section{Deplorable estado en que se hallaba el Bergantín San Francisco de Paula, el día 19 de Febrero de 1769, en la Altura de $\mathbf{5 2}$ grados $\mathbf{3 5}$ minutos de Latitud Austral} Alexo Berlinguero, Piloto del mismo Bergantín, hecho desde el Puerto Deseado, 1769

Como indica el historiador Mateo Martinic, el sistema marítimo del estrecho de Magallanes está formado por "canales y estrechos, por fiordos y bahías". Las temperaturas entre un lugar y otro son diferentes y oscilan, en general, entre los $2{ }^{\circ} \mathrm{C}$ y los $10^{\circ} \mathrm{C}$. El clima del lugar recibe influencias desde la parte continental, del Atlántico, del Pacífico y también del Polo, lo que explica que sea una zona lluviosa y ventosa. Además, son múltiples las corrientes marinas. Así, hasta el día de hoy navegar ahí es un desafío, el que debieron asumir las expediciones que se aventuraron a hacerlo y que explica por qué muchas de ellas naufragaron. 


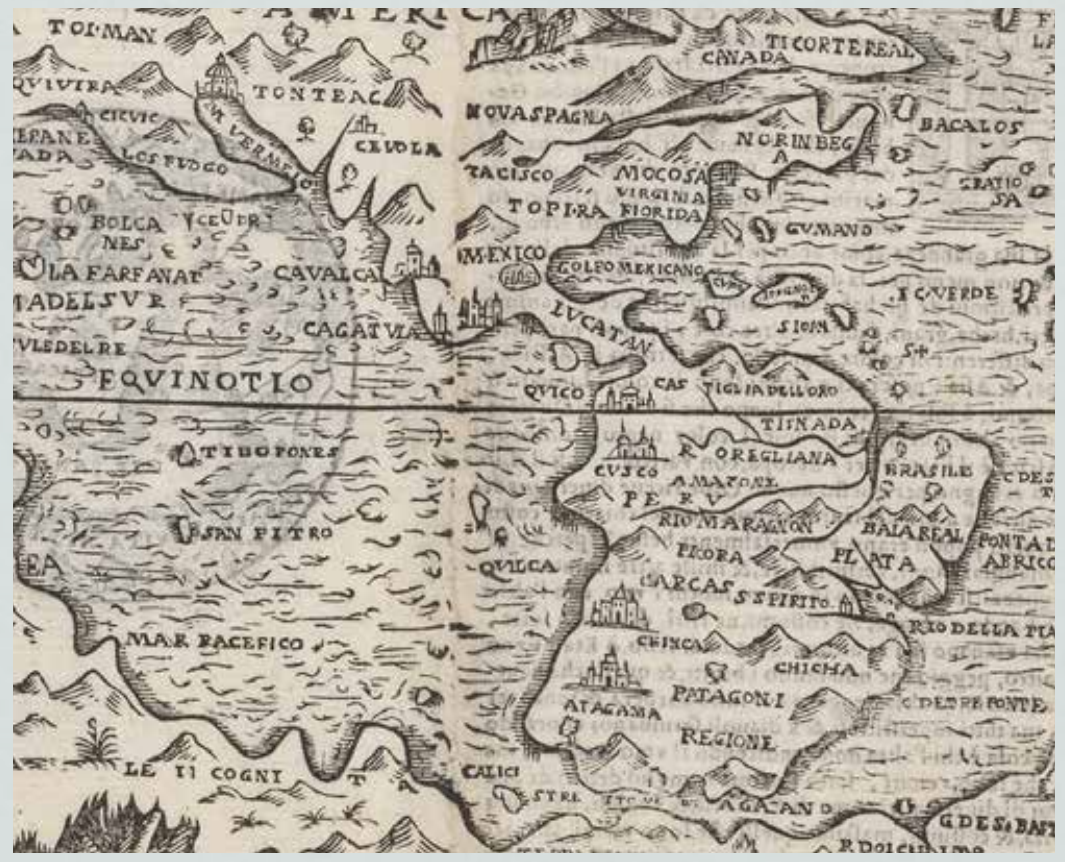

América

Giuseppe Rosaccio

Venecia, 1594

\section{La posesión del Estrecho}

Es importante precisar que el Estrecho, hasta 1552 , no era parte de Chile, sino de la provincia de Chincha, por lo que el botín que representaba resultaba ser aún más interesante, dado que era una jurisdicción completa la que estaba en juego.

Seguramente por esta razón es que la célebre familia alemana de los Fugger (Fúcares en español) se interesó en la zona, y durante los años I530 y I53I, se le encargó su administración, hecho que puede considerarse como una devuelta de favores políticos-económicos, ya que Carlos V fue erigido Emperador en I5I 8 gracias a la ayuda de esta familia. Este pacto lo demuestran los intentos de Capitulación entre ambas partes, que además revelan cómo cada uno buscaba proteger sus intereses. Desde España, por ejemplo, se esperaba que los alemanes se encargaran "a su costa" de llevar tres o cuatro navíos con gente, artillería, municiones y mantenimiento necesario para descubrir y pacificar todas las islas y la tierra firme desde el Estrecho hasta Chincha sin afectar al Rey de Portugal.

Con esto, la Monarquía buscaba que la influencia se diera principalmente hacia el norte (zona que incluía una parte del futuro Chile). Sin embargo, los alemanes también querían lo de más al sur, como se indica en uno de los manuscritos: "Asimismo, se han ofrecido los Fúcares de descubrir y poblar las tierras e islas que hay pasado el Estrecho de Magallanes delante". 


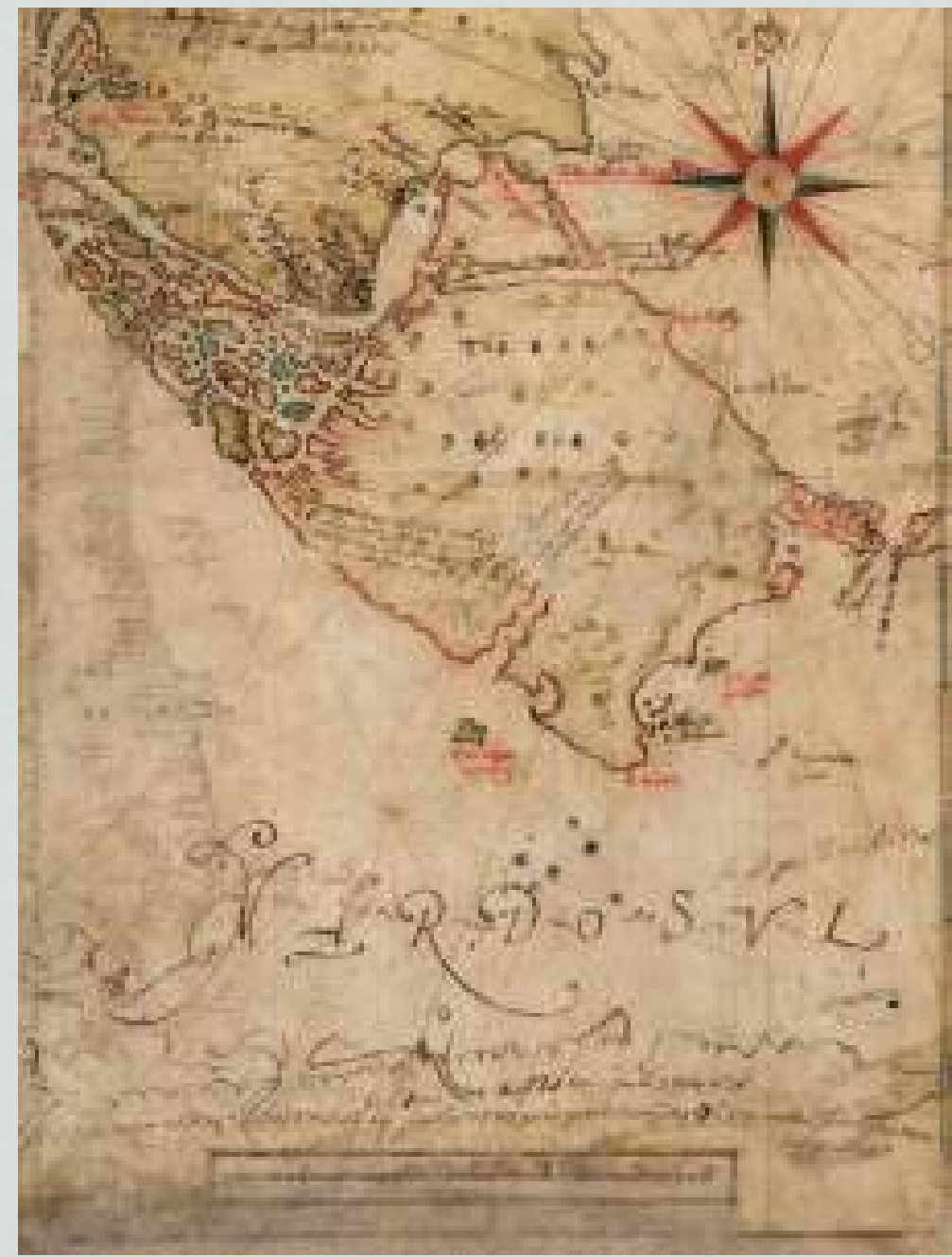

Imagen del Atlas

"Taboas geraes de toda a navegação"

João Teixeira, 1630

\section{Juan Ladrillero, piloto-cosmógrafo del Estrecho}

Juan Ladrillero fue un piloto experto que tuvo injerencia en las empresas de conquista de Juan de Vadillo, Pascual de Andagoya, Sebastián de Belacázar, Francisco Pizarro, Pedro de Valdivia y del Virrey Andrés Hurtado de Mendoza. Con Ladrillero se traza una larga línea de movilidad que va de Sevilla hasta las islas del Caribe, de Panamá hasta las selvas del Chocó y del Lago Titicaca hasta el estrecho de Magallanes.

La confluencia de prácticas cosmográficas, sentido comercial y consciencia-mundo hacen de este piloto alguien clave para entender cómo los nuevos conocimientos cosmográficos replantearon los significados geopolíticos de los pasos de Panamá y Magallanes como enlaces hemisféricos y globales que España debía custodiar ante las pretensiones de las monarquías rivales. 


\section{(4)}

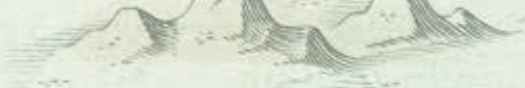

nevado $\partial_{e}$ fos for $_{\text {es }}$

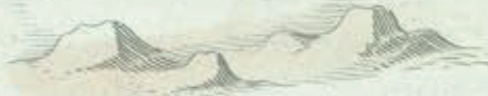

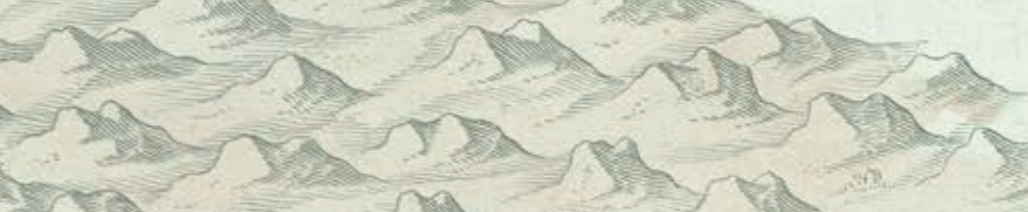

rom

ass mas

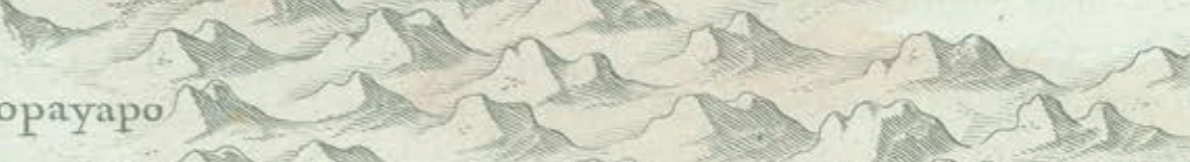

Tiendofa

D. Val de Gualco Da

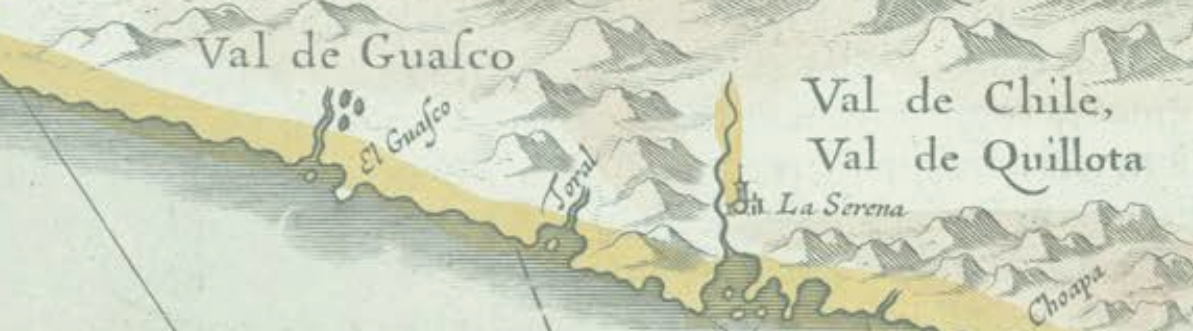

Val de Chil J - Maposcho

tho

Chucuito

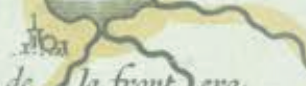

S. Iuan de Rla front om

Mears

foldes. Iago dela nueva Eftremadura

So

Promauca

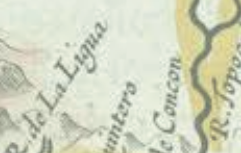

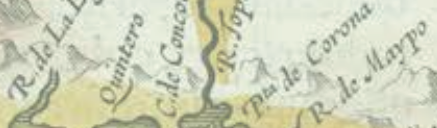

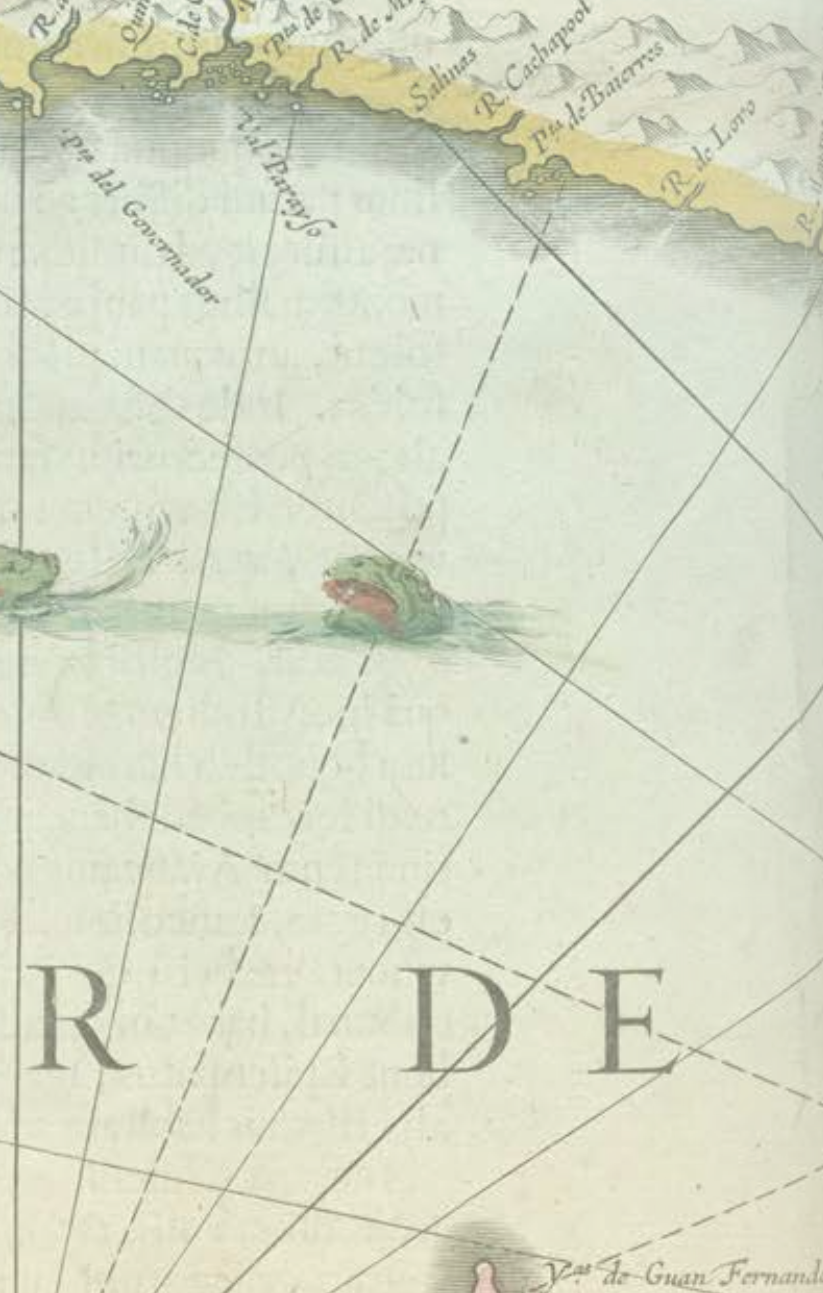


Capítulo 8

\section{El Estrecho, una solución para la "guerra de Chile"}




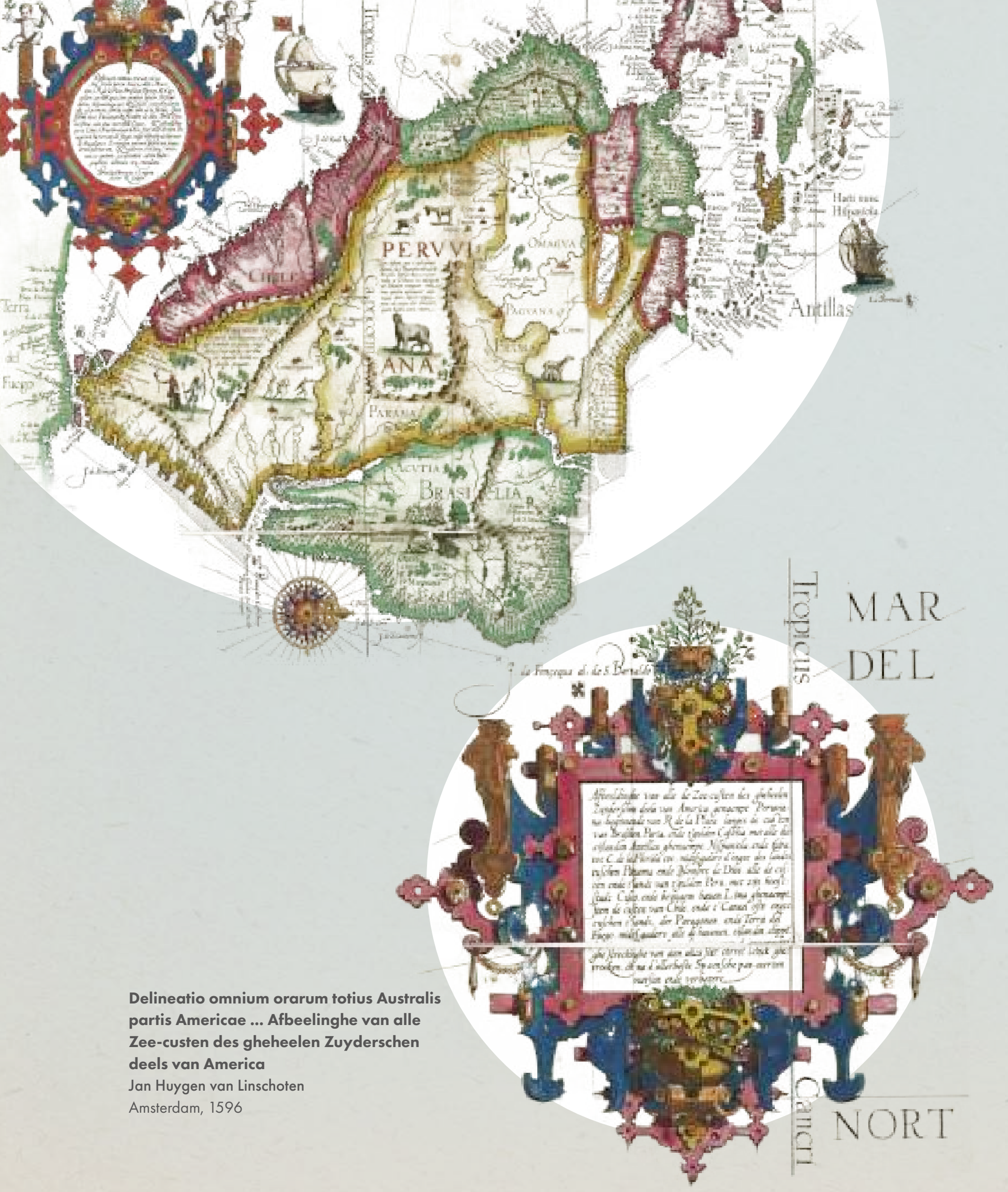


Haec pars Peruvianae, regiones Chicam \& Chile, complectitur, \& Regionem Patagonum

Petrus Plancius

Amsterdam, 1592-1594

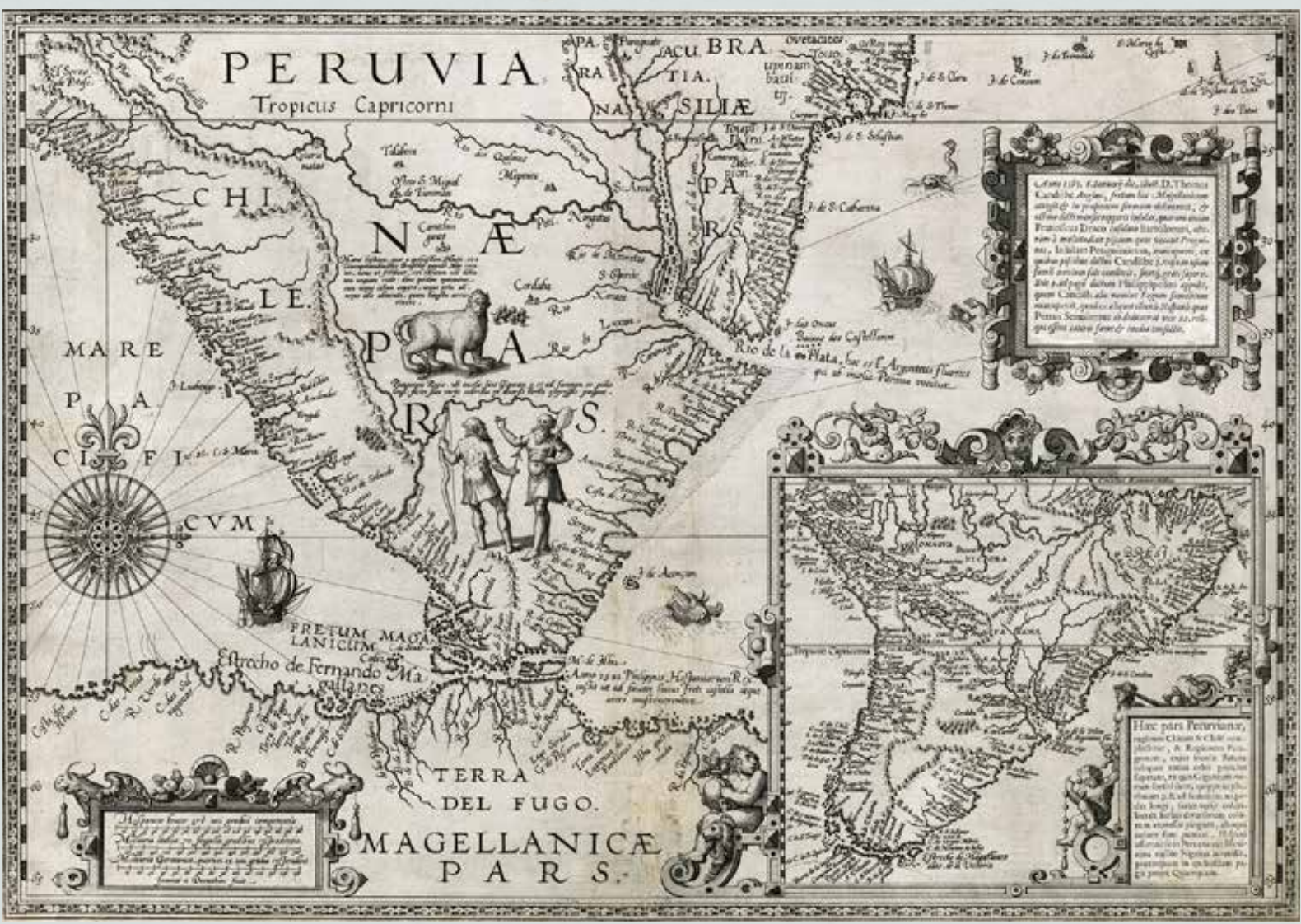

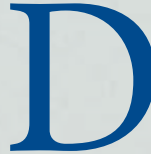

ESDE I 54I, LOS

CONQUISTADORES

ESPAÑOLES debieron

enfrentar la resistencia brindada por

la diversidad de pueblos nativos -

principalmente mapuches y pehuenchesdesplazados progresivamente al sur del río Bío-Bío. Esto implicó el primer fracaso del hasta entonces inalterable sistema de conquista implementado en América y el inicio de un complejo proceso de carácter militarista no concluido hasta la llamada "pacificación" de la Araucanía, concretada en I883, ya en época de formación del EstadoNación chileno.

En consecuencia, la imposibilidad de apropiarse del territorio obligó a los españoles a definir, durante los primeros siglos de ocupación (XVI-XVIII), diferentes estrategias para posicionarse de forma efectiva en la región habitada por los "araucanos", que era el nombre genérico con que se referían a los indígenas. 


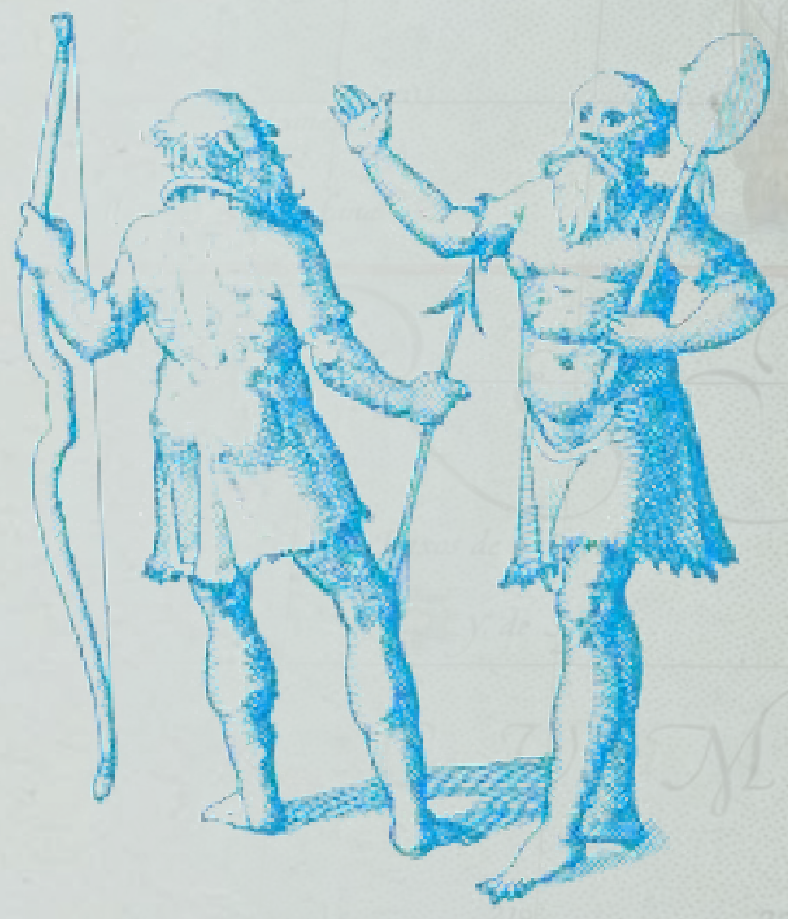

\section{La "guerra" de Chile}

La primera generación de españoles utilizó la única táctica posible para ir posicionándose en el espacio que se les resistía: avanzar cautelosamente mientras creaban pequeños asentamientos que les permitían salvaguardar lo conquistado. De esta forma fueron construyendo fuertes a lo largo del "valle de Chile" en medio del casi millón de autóctonos que poblaban la zona en las primeras décadas de conquista.

\section{Chile}

Hendrik Hondius, Amsterdam, 1638

Las primeras ciudades de Chile comenzaron a construirse a partir de los emplazamientos cerrados -fuertes-.

Tanto las ciudades como los fuertes sirvieron para consolidar el deseo de apropiación y también para generar una idea complaciente de seguridad, a pesar de que en la práctica los fuertes constituyeron la antítesis de esta idea, ya que dichos emplazamientos se consolidaron en el tiempo como espacios de intercambio e interacción entre españoles e indígenas.

Asimismo, ninguna de estas ciudades fue un espacio armonioso de seguridad, tal como supuestamente debían ser en la época, dado que si bien se advertía a las autoridades virreinales y metropolitanas de su creación, en ningún caso satisficieron las funciones para las que fueron concebidas.

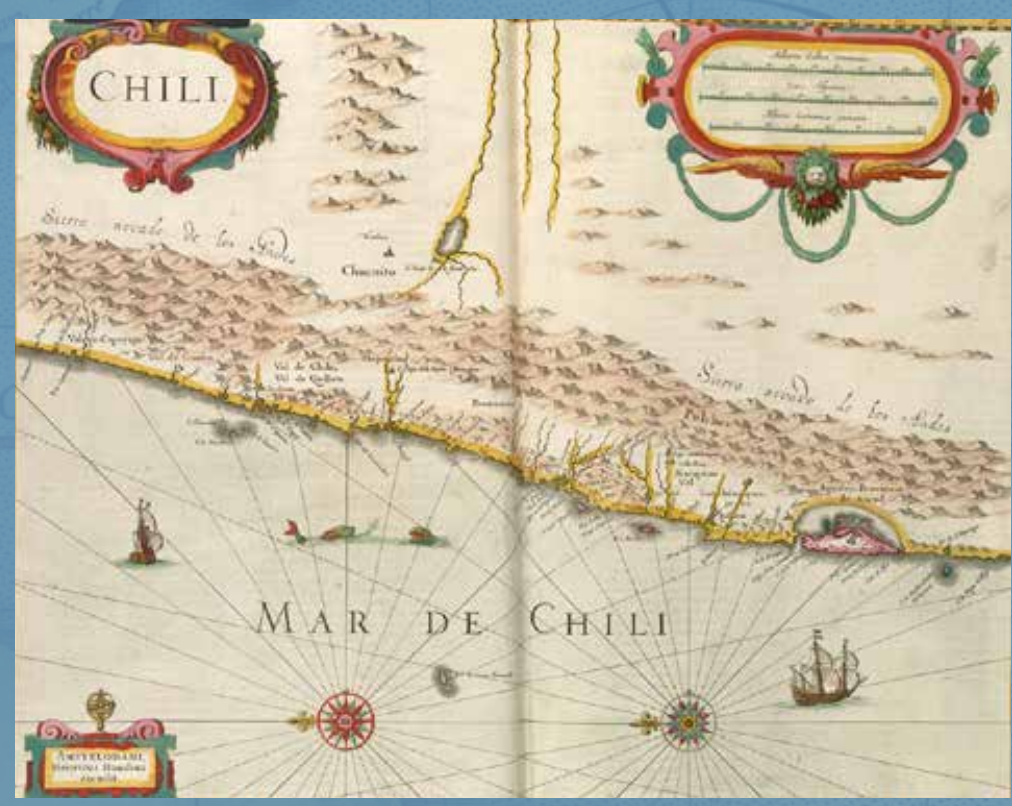




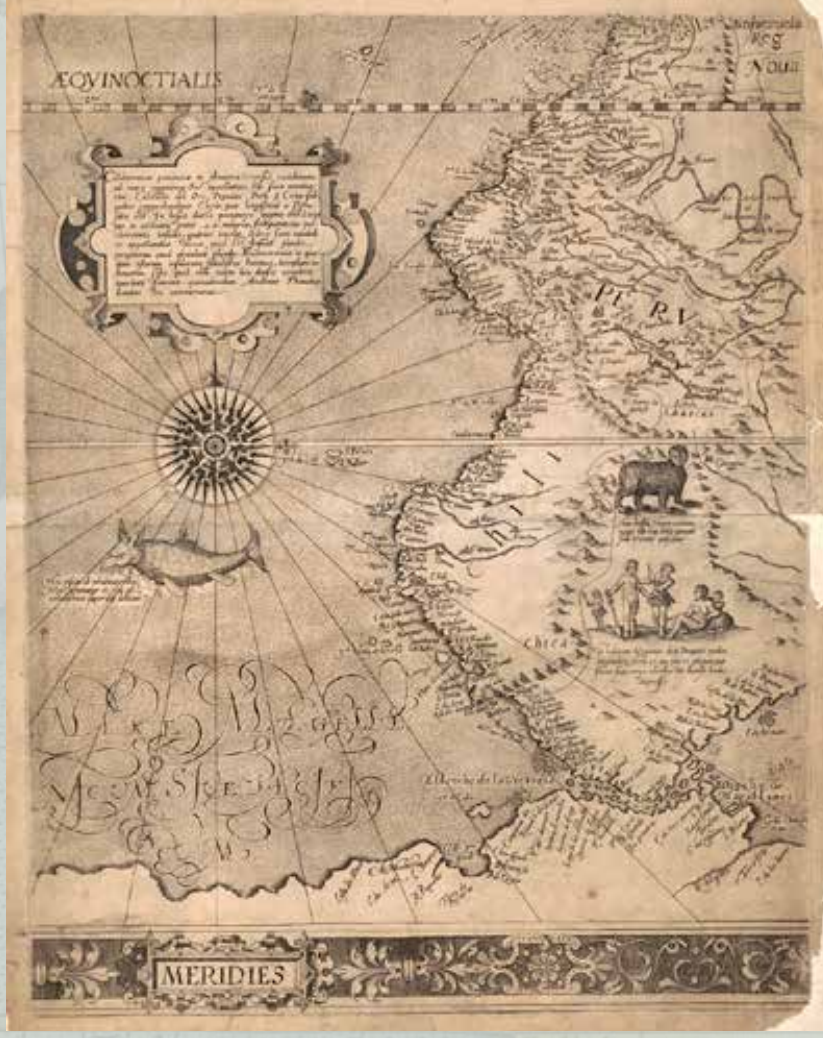

Mapa de Sudamérica

Gerhard Mercator, André Thevet.

Duisburgo, 1569
Fue por medio de un avance en "ondas" que los españoles pudieron instalar otros fuertes y generar una red de protección en el caso de ataques.

Esta forma de posicionarse constituyó, en definitiva, la manera de prosperar más coherente ante la falta de hombres y de recursos financieros y materiales. Así, a partir de estos emplazamientos cerrados -fuertes-, se comenzaron a construir las primeras ciudades del primigenio Reino de Chile: Santiago en I54I; La Serena en I544; Concepción en I550; La Imperial y Valdivia en I552, entre otras.
Uno de los efectos derivados de esta política de asentamiento en el territorio fue que este se proyectara como un espacio longitudinal, internamente fragmentado y deslindado entre "lugares de seguridad" y "lugares de riesgo". Se pasó de un espacio "salvaje" e inconmensurable" a un "espacio de itinerarios", de "estados" de guerra.

Esta estrategia, que discernía entre "esferas protegidas" y "no protegidas" -sistemas de inmunidad en palabras de Peter Sloterdijk-, tuvo como consecuencias calmar la ansiedad de capturar un espacio inexplorado, la instauración de la primera 
fragmentación en la percepción del espacio chileno y el usufructo de los sentimientos de seguridad de lo conquistado y de encantamiento con lo que no se poseía. Todo esto revela que lo acontecido en Chile no solo estuvo vinculado a la conquista del territorio, sino también a problemáticas concernientes a las sociedades modernas.

Este posicionamiento favoreció que el enfrentamiento entre españoles e indígenas se entendiera como una guerra, cuyos episodios sucedidos al sur de Santiago quedaran comprendidos en el concepto de "la Guerra de Arauco". podría aseverar, se relaciona de manera "estrecha” con la imposibilidad de llegar al estrecho de Magallanes. La guerra habría nacido, en parte, por dicha imposibilidad.

Además, por la importancia misma de este pasaje-mundo es que se intentó solucionar el conflicto, sobre todo en el siglo XVI, ya que las autoridades en España no querían perder el interés en un lugar que siempre fue codiciado por los hispanos en Ghile.

La conformación de la idea de guerra, se

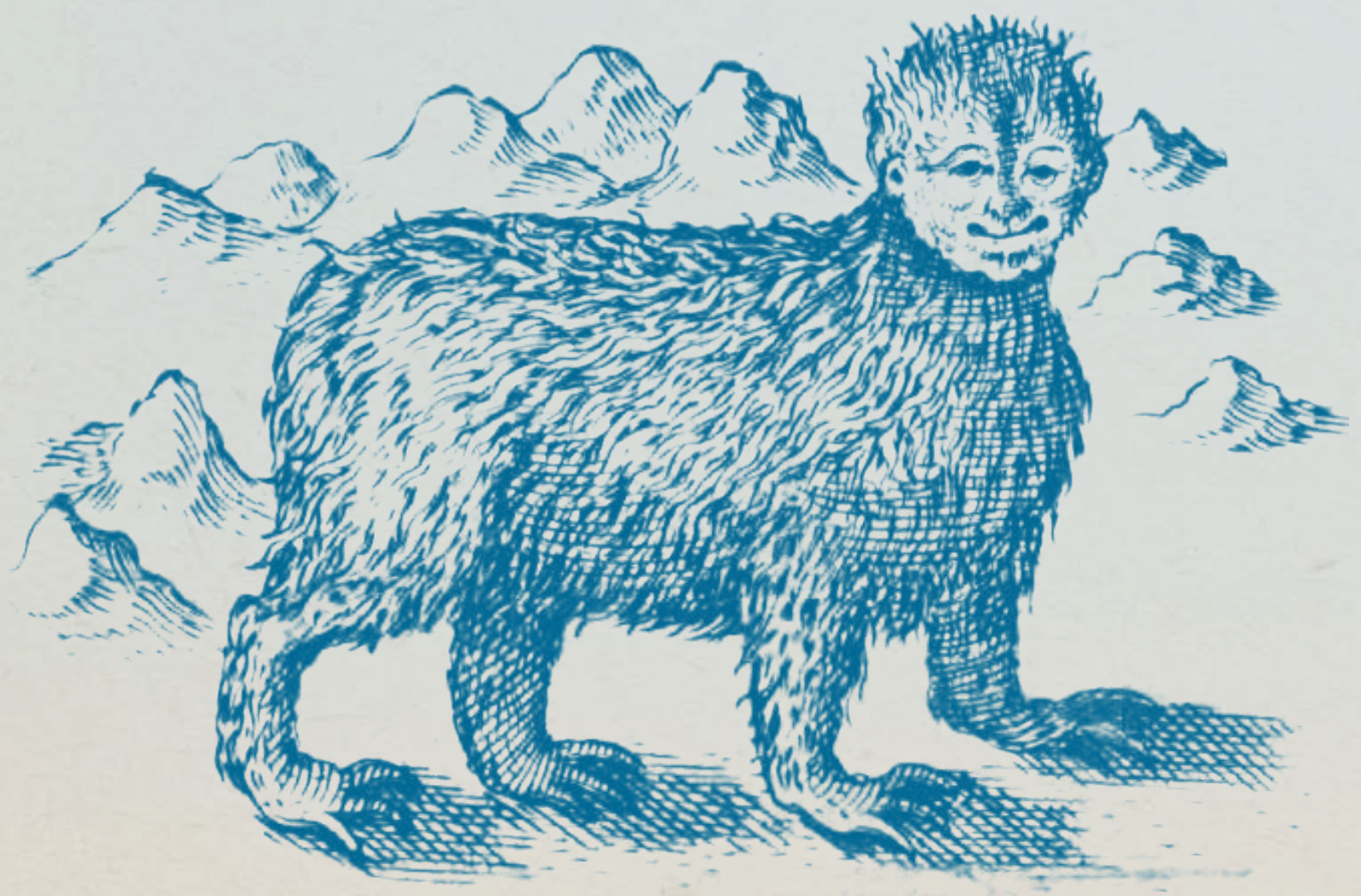




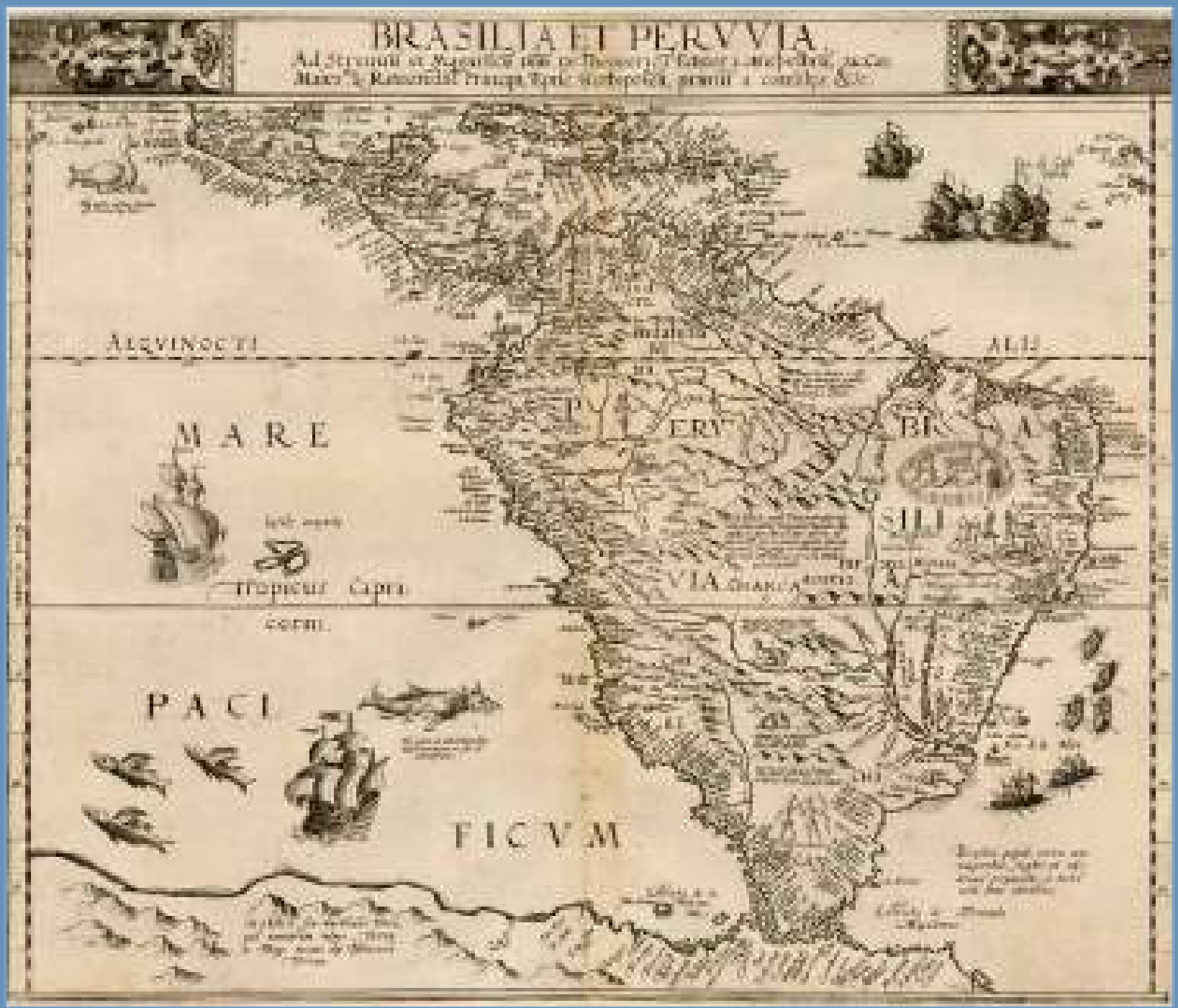

\section{Brasilia ef Peruvia}

Cornelis De Jode, Amberes, 1593

Múltiples fuentes muestran la importancia del Estrecho como una vía de solución al escenario bélico y, al mismo tiempo, como una ruta geopolítica de protección del Virreinato y de comercio con Oriente.

Ejemplos son los testimonios de Lorenzo Bernal, quien en 1569, en una crítica al gobierno de Bravo de Saravia le pide socorro al Rey para la continuación de la guerra y lo insta a "navegar el Estrecho, porque se pasaría acá todo el contrato de Tierra Firme y sería cerrar aquella sepoltura de españoles"; y de Melchor Bravo de Saravia, quien en 1571 le escribe al Rey con respecto a la guerra de Arauco y los asuntos del reino, y lo interpela para que envíe ayuda y que "sería lo más acerłado enviarla por el Estrecho". 


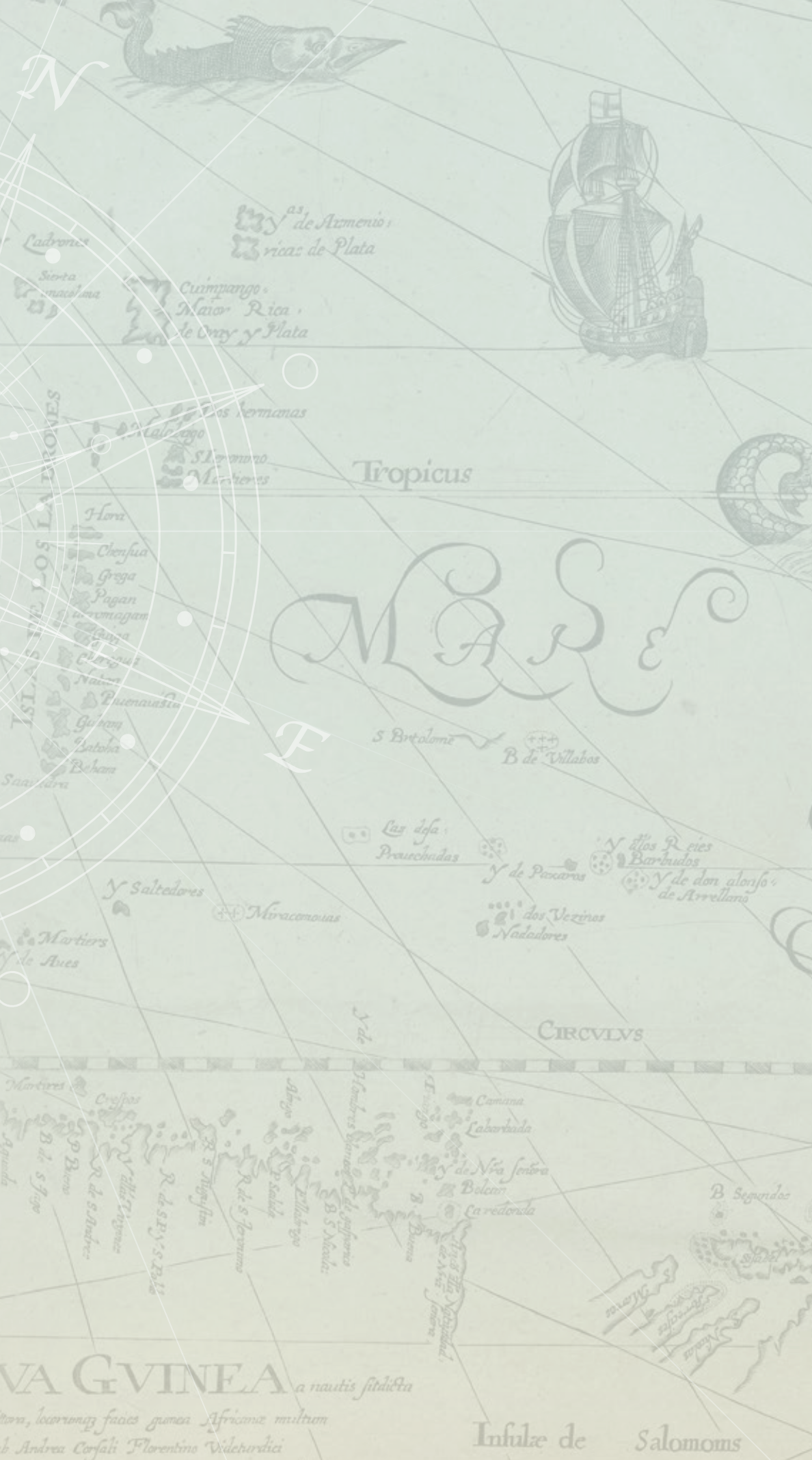


Capítulo 9

Un problema geopolítico: piratas y corsarios ingleses, franceses y holandeses 


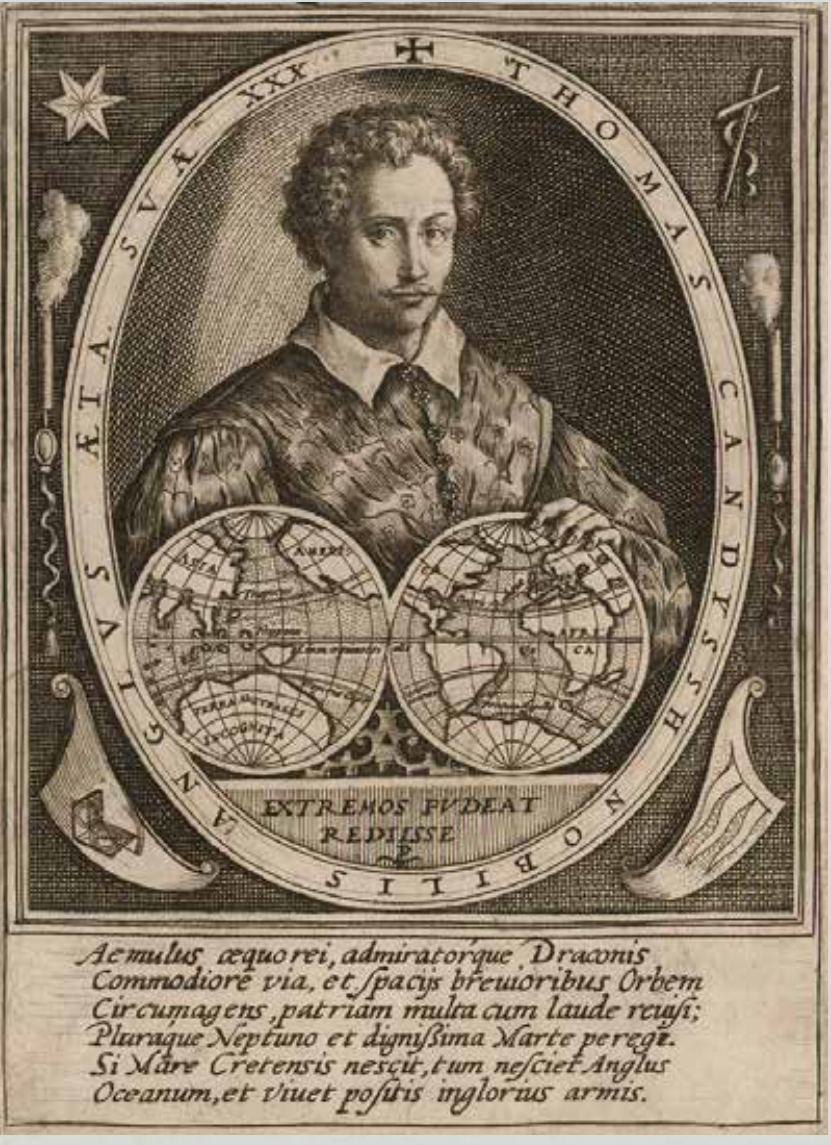

Thomas Cavendish y el mundo

Crispin Van Passe

Colonia, 1598
$\mathrm{E}$

N EL SIGLO XVI el reino de Chile, el territorio más austral de los dominios españoles en

América, sirvió tanto de resguardo del virreinato peruano por el sur como de administrador de la ruta marítima de entrada al océano Pacifíco. Es por ello que fue considerado por la burocracia administrativa de España e Indias como un área estratégica cuya preservación era indispensable, más aún después del progresivo incremento del comercio y de la cantidad de mineral precioso que, desde mediados del siglo, partía rumbo a la metropoli. Todo esto propició que potencias europeas hostiles a España -Inglaterra, Holanda y Francia, principalmente- orientaran cada vez más su mirada hacia el vasto imperio ultramarino, conscientes del papel clave que jugaba la plata en la hegemonía de la monarquía española en el viejo continente.

Dicha situación derivó en la aparición de piratas y corsarios en las costas americanas. A raíz de esto, dada la importancia estratégica de Chile, se justificaron expediciones y proyectos que tenían como objetivo establecer fortificaciones en el estrecho de Magallanes y en torno a la ciudad y puerto de Valdivia, entre otros núcleos costeros. 


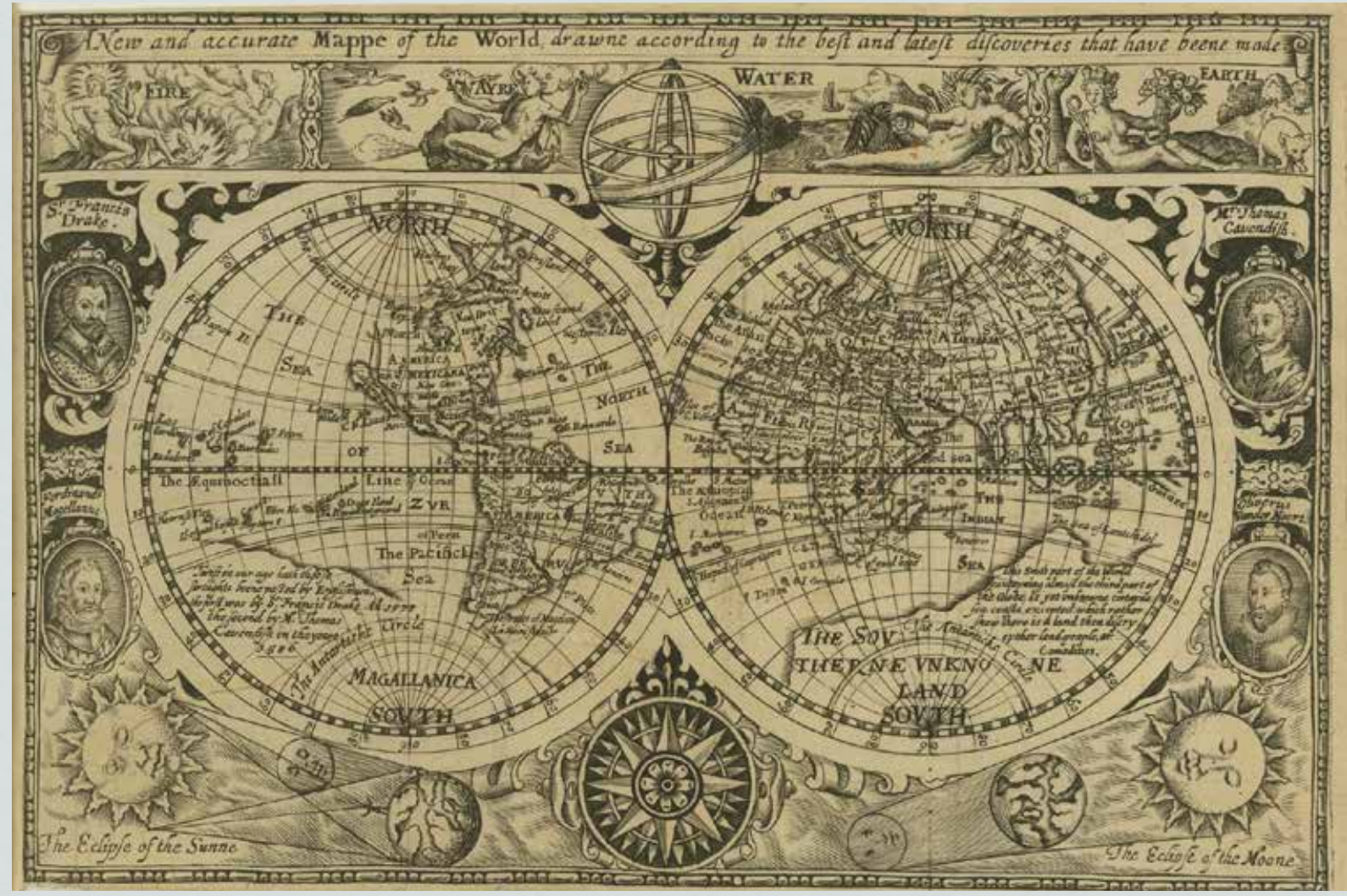

A New and accurate Mappe of the World, drawne according to the best and latest discoveries that have been made Robert Vaughan Londres, 1628

El estudioso Joaquín Zuleta señala cómo el Virrey Toledo, en I573, ya había imaginado algunas líneas de protección para la zona y el continente: "propuso a la Corona emprender un completo sistema de fortificación portuaria: Arica, Chile, el Callao, Guayaquil, Paita, Trujillo y Santa. La respuesta fue negativa, lo que deja ver que la Corona confiaba en que el istmo de Panamá y el estrecho de Magallanes garantizaban la defensa natural del virreinato". Sin embargo, la defensa natural no fue suficiente y en septiembre de I578 el corsario inglés Francis Drake alcanzó el
Pacífico luego de atravesar el Estrecho. Esta irrupción, avalada por la Reina de Inglaterra, afectó directamente a varios puertos americanos gobernados por los españoles, Valparaíso y Coquimbo, entre ellos.

La "entrada" de Drake se vio facilitada, principalmente, debido a que ya se había establecido una ruta de comercio clara por Panamá y a la imposibilidad de llegar por tierra al Estrecho a causa de los conflictos con los nativos, razón por la que no existía contingente español en la zona. 


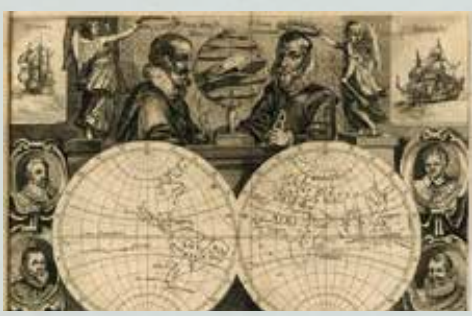

Mapa del mundo de las circunnavegaciones y las imágenes de los principales capitanes que las comenzaron

Willem Corneliszoon Schouten

\section{Amsterdam, 1618}

La imagen presenta a seis de los más reconocidos navegantes que circunnavegaron el globo a partir de 1520 . En primer plano, en el olimpo, se encuentran Fernando de Magallanes y Willem Schouten, descubridores del estrecho de Magallanes y del Cabo de Hornos (1616), respectivamente. A sus costados se ven las dos naves triunfadoras de ambas expediciones: La Victoria y la Eendracht. Además, rodean las esferas cuatro grandes navegantes: Sir Francis Drake, Olivier van Noort, Thomas Cavendish y Joris van Spilbergen.

\section{Los miedos a las entradas piratas}

La apertura que lograron los piratas causó preocupación entre las autoridades, ya que no solo se trató de ataques a la soberanía, sino que, también, al propio orden cultural y religioso, pues se temía que el culto luterano ingresara a Chile y llegara a los indígenas. El miedo al extranjero se basaba en las posibles uniones que estos pudieran formar con los nativos, lo que llevaría a la conquista de Chile a "foja cero" y desestabilizaría la empresa imperial del resto de América. Como precisa el historiador Gabriel Guarda, América corría el peligro de partirse en dos.

\section{La Mocha} Joris van Spilbergen Leiden, 1619

Si bien el paso de piratas y corsarios fue un problema en todas las costas americanas, Chile se vio más afectado porque fue ahí donde aquellos hacían su primera pausa, la que no era en cualquier tierra. Elegían islas que por lo general estaban despobladas de europeos o tierras de indígenas consideradas perdidas o rebeladas. Una de ellas fue la isla Mocha -punto marítimo intermedio entre Concepción y Valdivia-, que constantemente acogió la visita y/o se vio afectada por los saqueos de los corsarios y piratas, quienes, no obstante, tuvieron predilección por los puertos de Chile para cometer sus ataques.

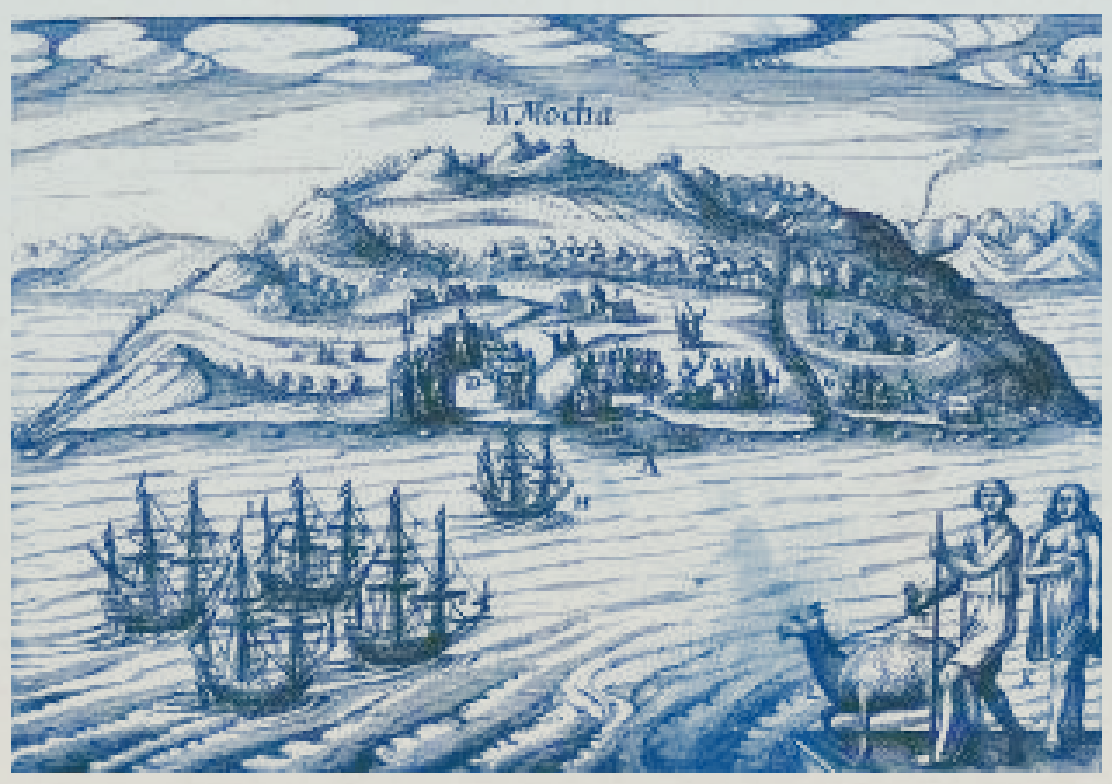




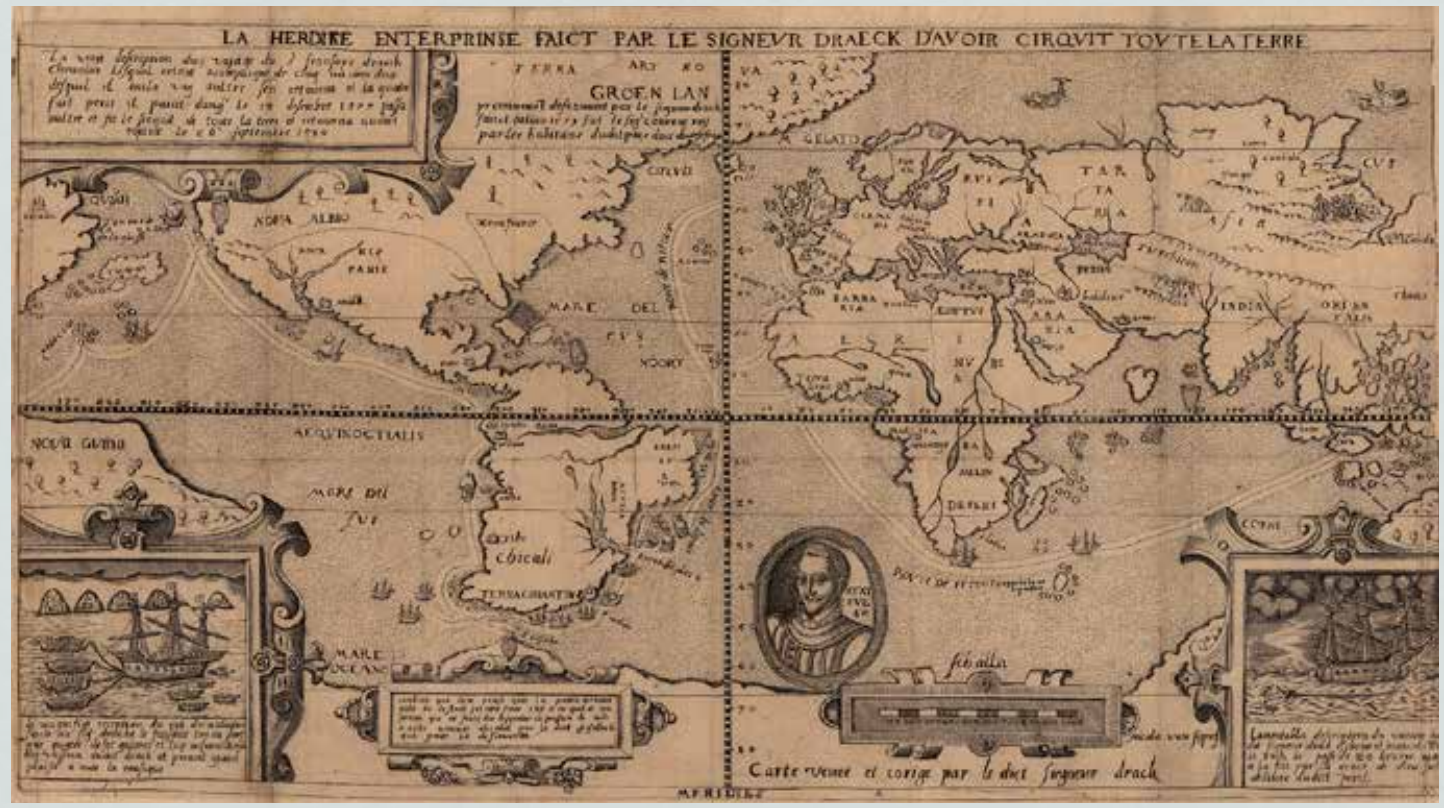

La heroique enterprinse faict par le Signeur Draeck d'avoir cirquit toute la terre

Antoine Robinot París, 1641

Que los piratas y corsarios estuvieran respaldados políticamente por algunos Estados y Reinos europeos obligó a la Corona española a reaccionar prontamente. Para ello, instauró una armada y un sistema de protección en el Estrecho.

Así, en I58I, año de máximo esplendor territorial de la Monarquía española al anexar Portugal luego de la proclamación de Felipe II como su rey, la Corona creó una expedición inaudita para proteger la zona austral.

\section{Comandada por Diego Flores y Pedro} Sarmiento de Gamboa, la expedición partió desde Cádiz con 23 barcos y alrededor de 3000 personas.
El objetivo de esta armada era frenar el paso enemigo por el Estrecho y sentar las bases para un posicionamiento que permitiera tanto la protección de América como el comercio con Asia. Además, reforzaría la imagen militar de la Monarquía al fortificar parte del Estrecho, ya que requeriría una logística militar y tecnología de punta, lo que no pasaría desapercibido por sus adversarios.

Sin embargo, a causa de los recurrentes problemas entre los líderes de la expedición, esta fue un fracaso. Sarmiento llegó a la región austral, pero con un contingente fracturado por disputas y deserciones, lo que sumado a la falta de medios no le permitió establecer un asentamiento definitivo. 


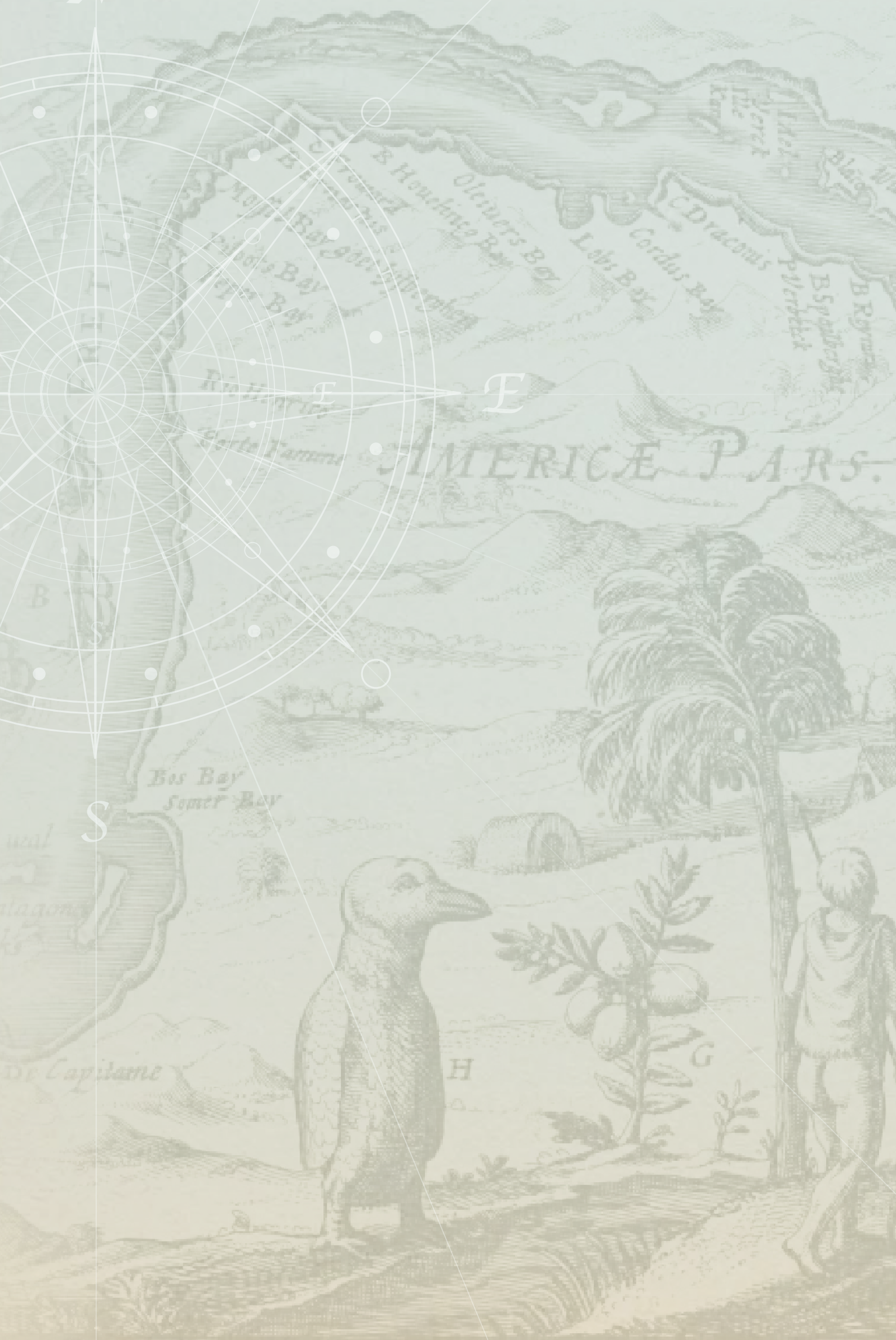


Capítulo 10

El Estrecho como un definidor de
la experiencia de "estar en Chile" 


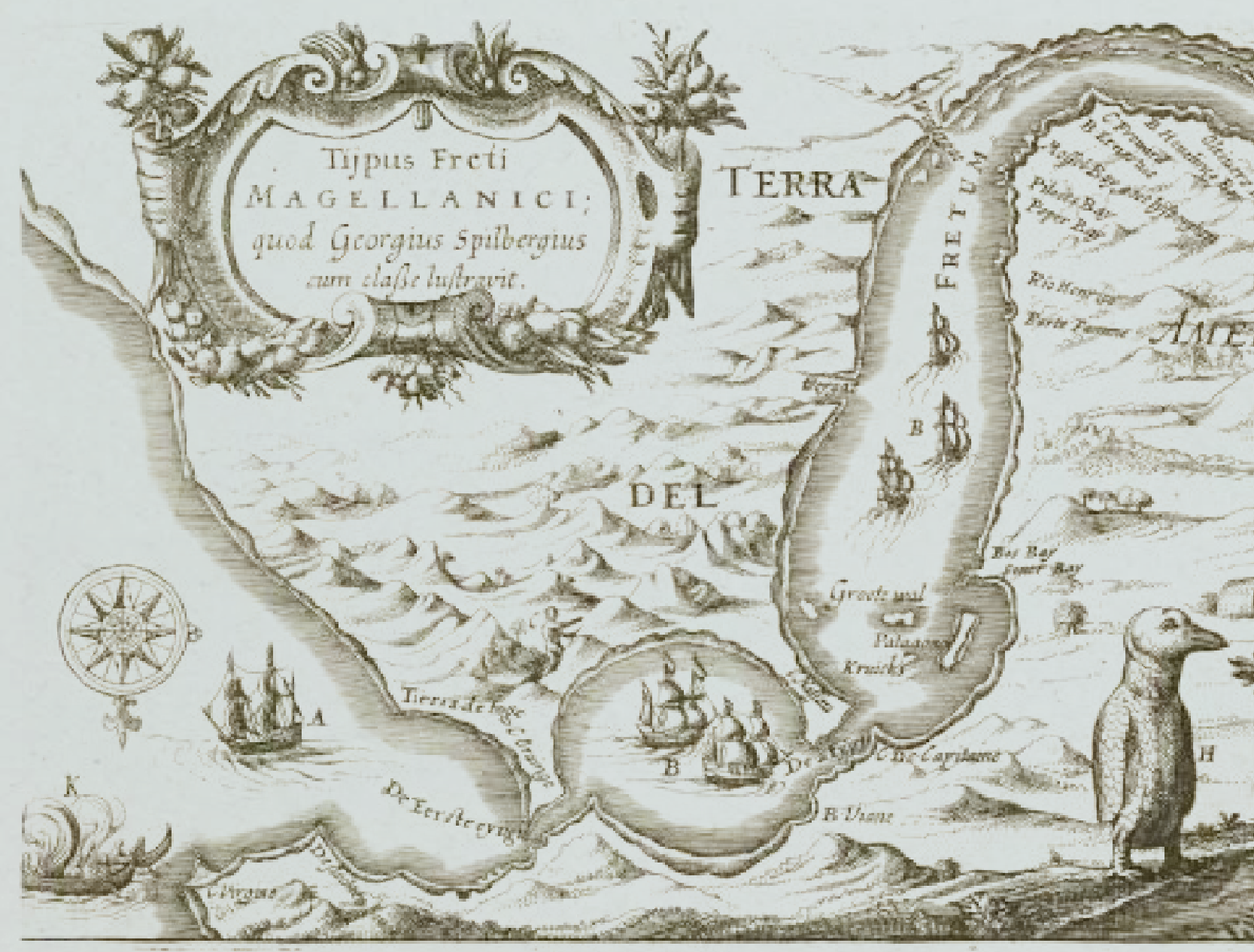

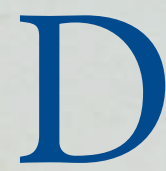

ESDE QUE FUE

DESCUBIERTO EL ESTRECHO

DE Magallanes en I520, el

relato que comenzó a escribirse acerca del acontecimiento se caracterizó por un tono que hizo notar las dificultades asociadas a la proeza. Así, desde un principio la zona fue descrita por relaciones como las de Antonio Pigafetta, Sebastián Elcano y Ginés de Mafra como inhóspita, fría y de difícil tránsito.

\section{Una "isla" estrecha}

La pertinencia de esta narrativa puede verse confirmada en lo difícil que fue crear un asentamiento o llegar a la zona durante el siglo XVI. De hecho, desde Europa, hasta 1578 el Estrecho no pudo ser atravesado. Además, ni Carlos V ni sus colaboradores facilitaron la realización de grandes expediciones luego de que algunas tentativas 
Tijpus Freti Magellanici, quod Georgius Spilbergius cum classe lustravit. Nicolaes van Geelkerchen Leiden, 1619

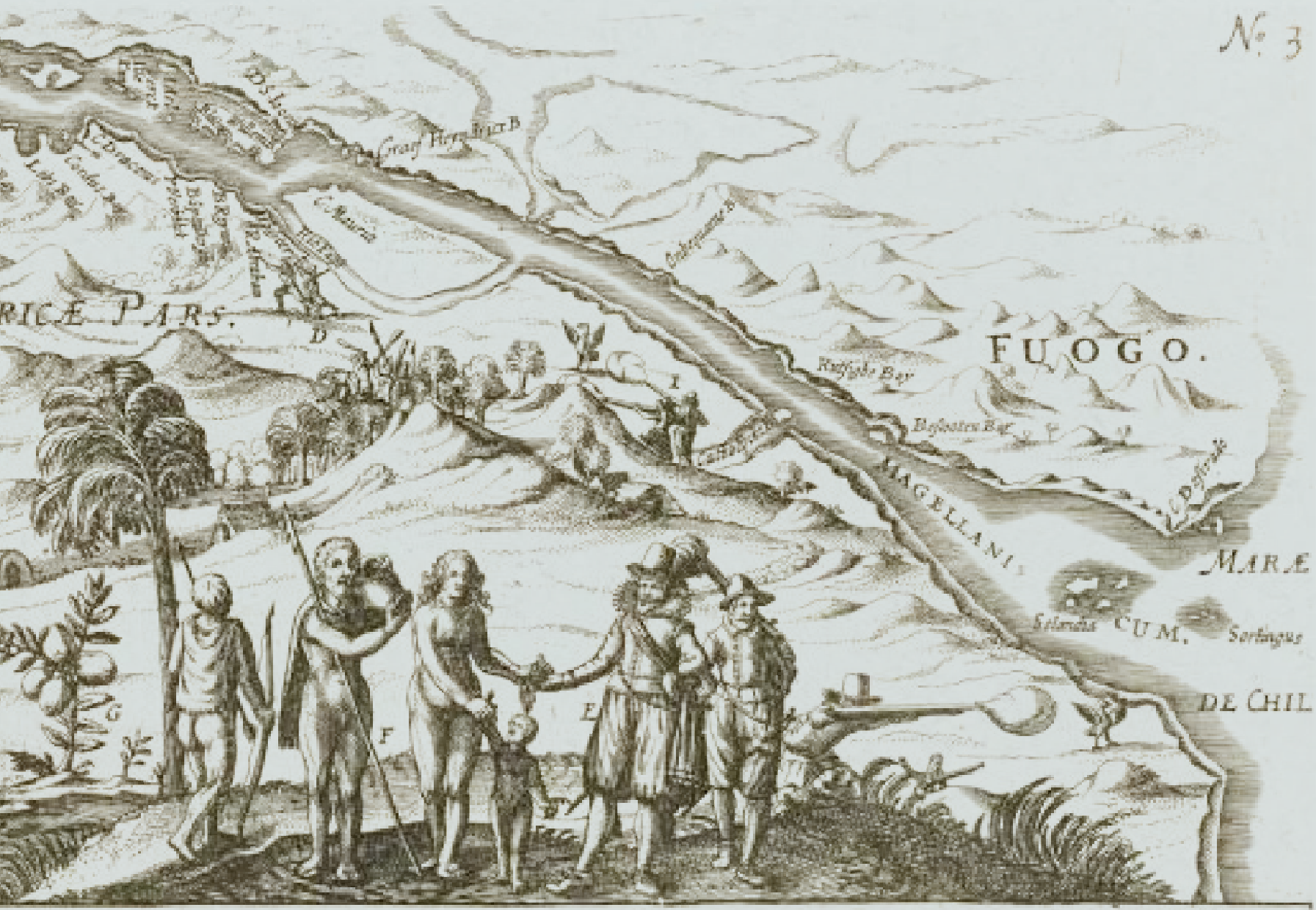

fracasaran y se perdieran numerosos medios en el proceso. Estas causas y otras más -por ejemplo, la presión que ejercieron sobre la Monarquía los conquistadores apostados al norte de América, quienes precisaban mantener como único paso a las Indias el que se encontraba en la actual Panamá-, hicieron que la zona del Estrecho y sus tierras aledañas fueran vistas pospuestas de ser intervenidas directamente por parte de la corona, lo que con el correr del tiempo significó que dichas tierras se “aislaran”, literalmente.

En efecto, es posible ver en el Islario general de todas las islas del mundo, obra del célebre cartógrafo Alonso de Santa Cruz, quien vivió gran parte del XVI (I505I567), cómo las tierras magallánicas fueron presentadas como la "última isla del mundo". 
Esta insularidad en torno al Estrecho pudo potenciarse gracias a su distancia respecto a los centros de intercambio y de poder de la época. Al ser visto como un trozo en la lejanía del extremo del globo, el Estrecho pudo consolidarse como la antípoda del mundo conocido.
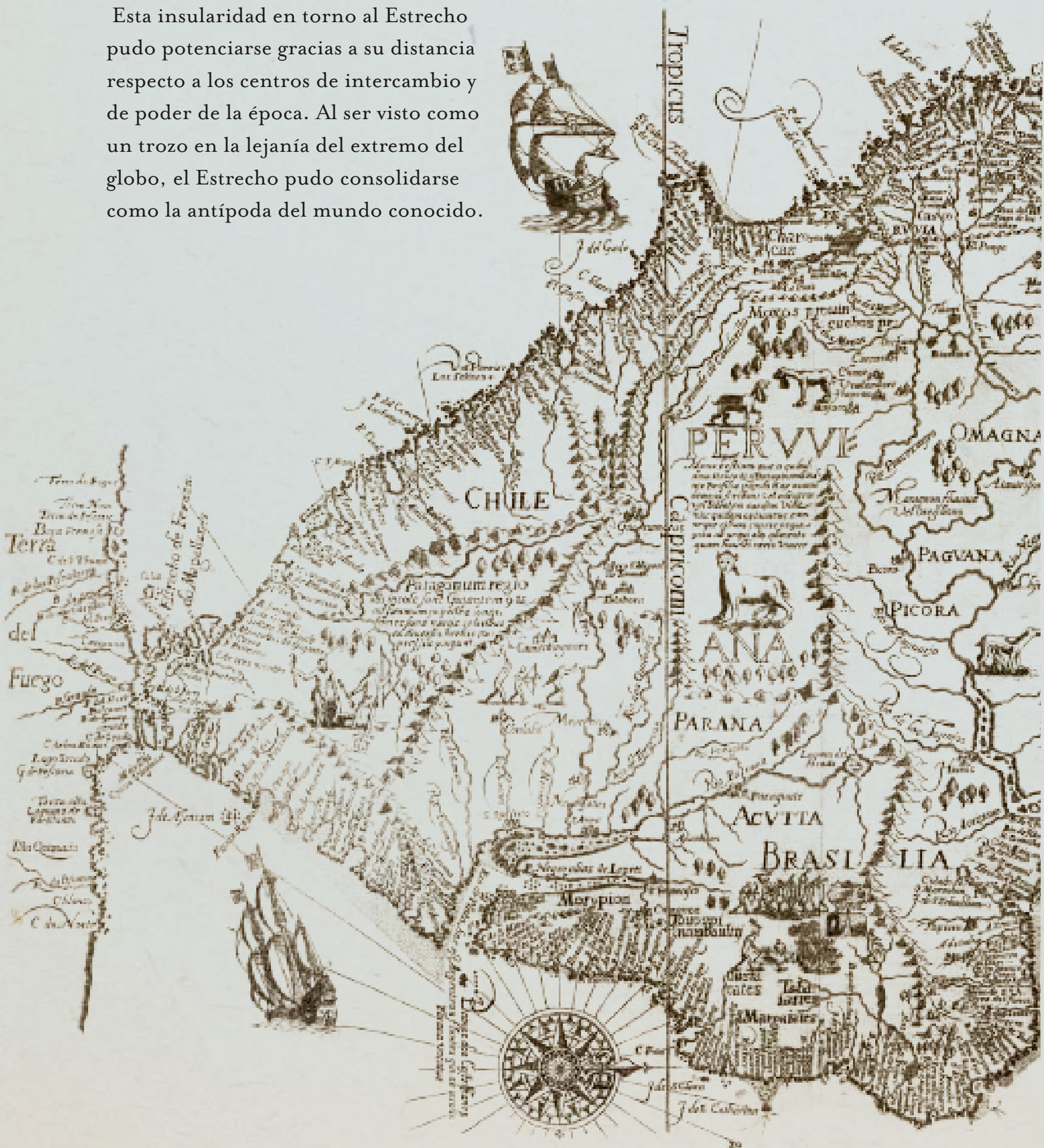


\section{VII. \\ GỶab Denfolländern im Fretoalleciner B. 3 nfel begegnit.}

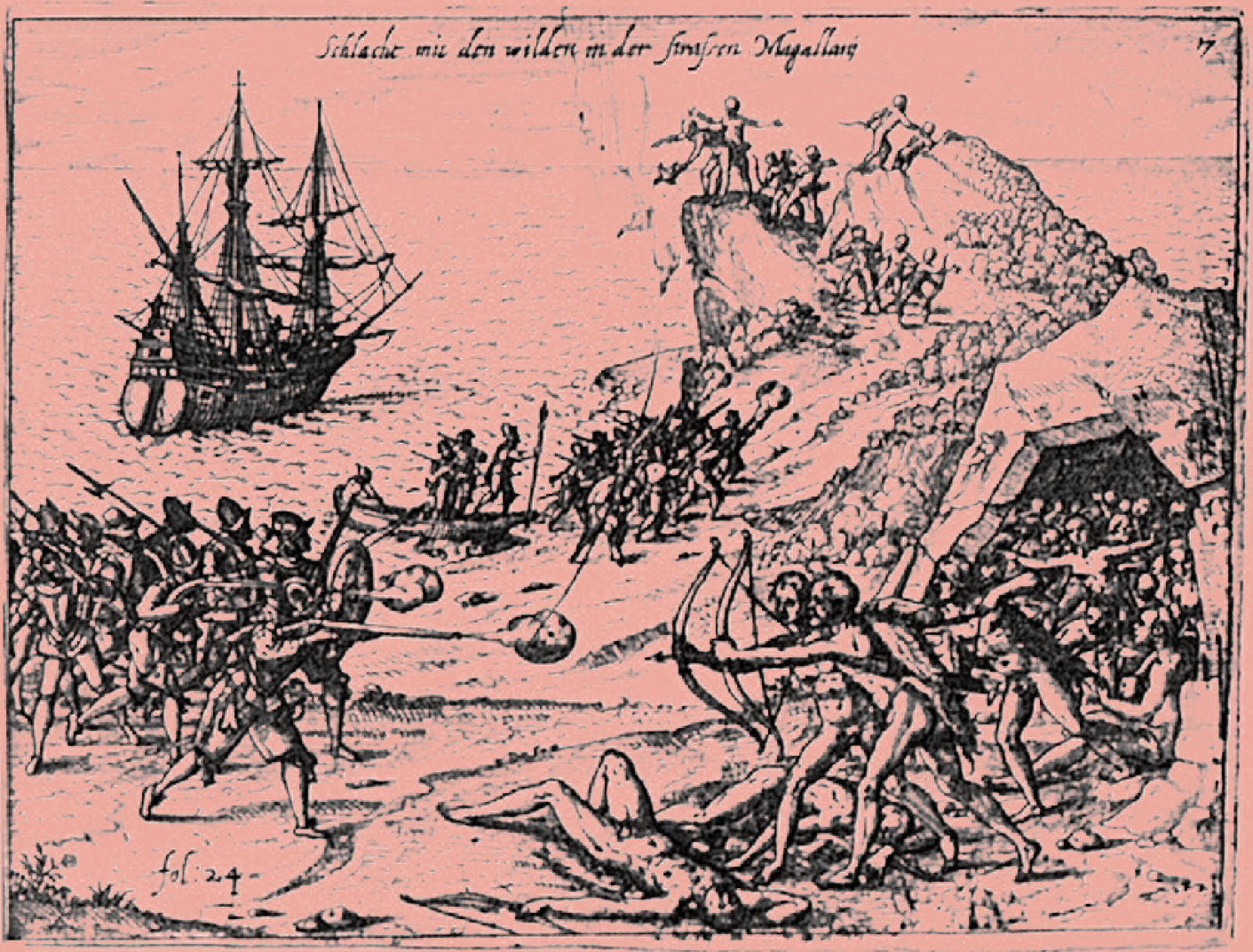

\section{"Soldados europeos a la llegada del estrecho de Magallanes" Theodore De Bry, 1601}

El grabador y editor de libros Johann Theodorus de Bry, nacido en Lieja, fue unos de los principales promotores de imágenes sobre América durante el siglo XVI. Sus obras representaron tanto lugares americanos como a pueblos originarios de distintas latitudes, de quienes destacó sus vestimentas, armas, comidas, etc. También expuso una serie de episodios referidos a la llegada europea al continente y a los intentos de tomar posesión del lugar. Uno de estos episodios muestra el arribo a la zona magallánica, que es exhibida como un escenario de guerra, algo muy similar a lo transmitido por los españoles que habitaban entonces en Chile. 


\section{El estrecho y la experiencia de "estar en Chile"}

Ahora bien, hemos notado que con el paso de los años, todas estas ideas y percepciones -antípoda, insularidad, accidente, estrechez en el extremo del mundo-, dadas por la primera expedición que atravesó el Estrecho, además de la posterior imposibilidad de posicionarse ahí, fueron utilizadas para canalizar una parte del discurso sobre la imagen de Chile y para definir la experiencia de los españoles residentes en el territorio.

Así, hubo una constante búsqueda por encapsular la experiencia española dentro de una serie de palabras y percepciones asociadas a esta. Jean-Marc Ferry, el filósofo francés, se refiere al fenómeno como una experiencia que fue "tematizada" y que por eso devino en discurso, ya que se utilizaron, pragmáticamente, ciertas palabras vinculadas al conjunto de experiencias de acuerdo a la situación que se quería describir.

Ejemplos de la relación que existió entre las narrativas surgidas del paso por el Estrecho y de la experiencia de los españoles de habitar en Chile hay varios.
Uno es el uso de la idea de "estrechez" en el "extremo del mundo", la que surgió a raíz de la geografía, de las experiencias del paso y de los intentos frustrados por atravesar el Estrecho, idea que años después se reutilizó para describir las propias penurias materiales y las adversidades de la guerra contra los indígenas.

Diversos registros demuestran todo esto. Un ejemplo fue el amplio uso en los documentos de la época de la palabra "extremo(as)", tanto en su forma adjetiva como sustantiva. Esto se puede ver en cartas como las dirigidas al rey por parte de Melchor Bravo de Saravia y Sotomayor, gobernador en I569, en la que se refiere a "la extrema necesidad y riesgo en que hemos estado", y en la de Tomás de Olavarría en 1602, quien le escribe "estoy corrido de estar arrinconado en este Reino y deseo con extremo salir de él. 

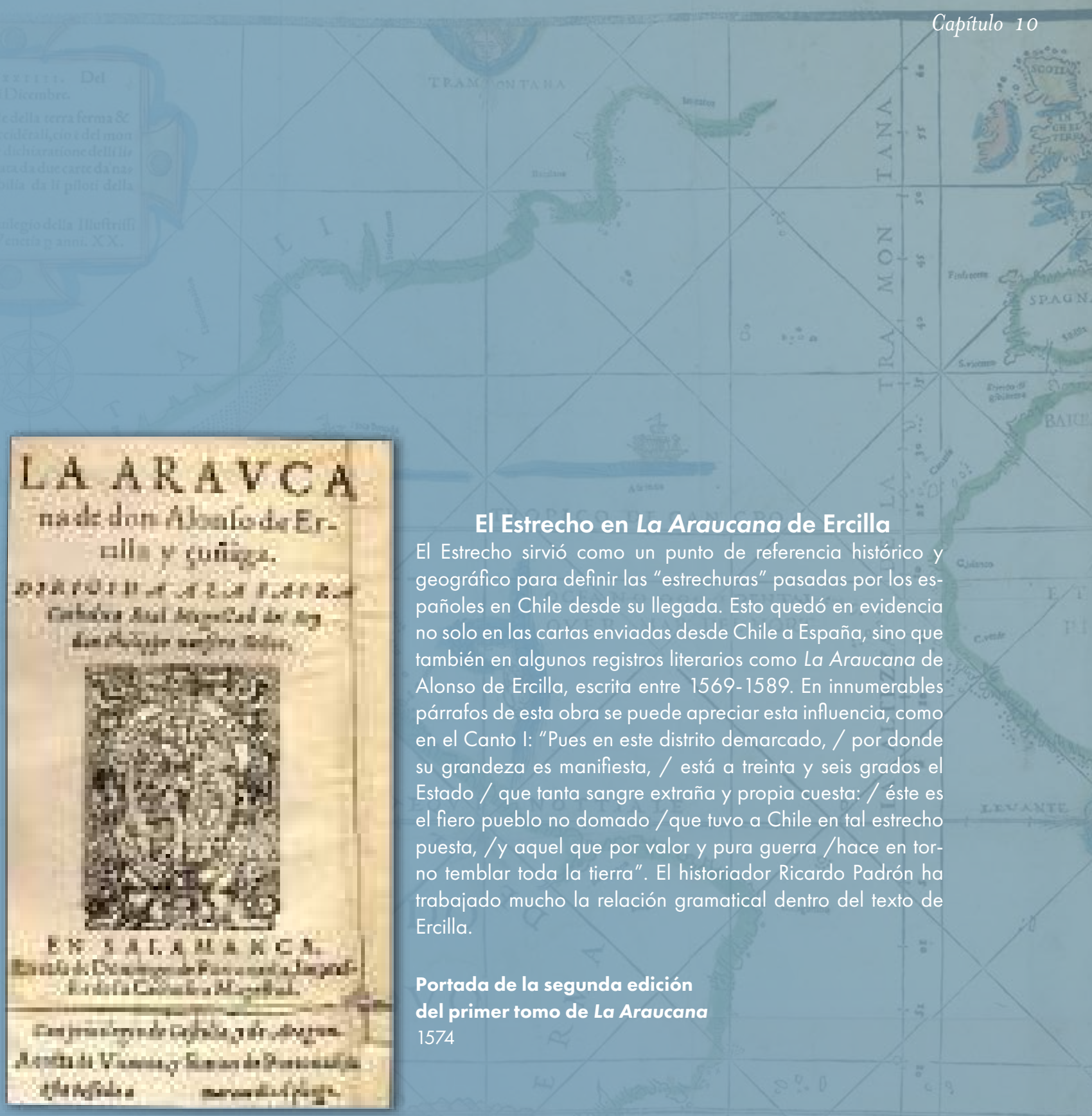

El Estrecho sirvió como un punto de referencia histórico y geográfico para definir las "estrechuras" pasadas por los españoles en Chile desde su llegada. Esto quedó en evidencia no solo en las cartas enviadas desde Chile a España, sino que también en algunos registros literarios como La Araucana de Alonso de Ercilla, escrita entre 1569-1589. En innumerables párrafos de esta obra se puede apreciar esta influencia, como en el Canto I: "Pues en este distrito demarcado, / por donde su grandeza es manifiesta, / está a treinta y seis grados el Estado / que tanta sangre extraña y propia cuesta: / éste es el fiero pueblo no domado / que tuvo a Chile en tal estrecho puesta, /y aquel que por valor y pura guerra / hace en torno temblar toda la tierra". El historiador Ricardo Padrón ha trabajado mucho la relación gramatical dentro del texto de Ercilla.

Portada de la segunda edición del primer tomo de La Araucana 1574 


\section{Conclusion}
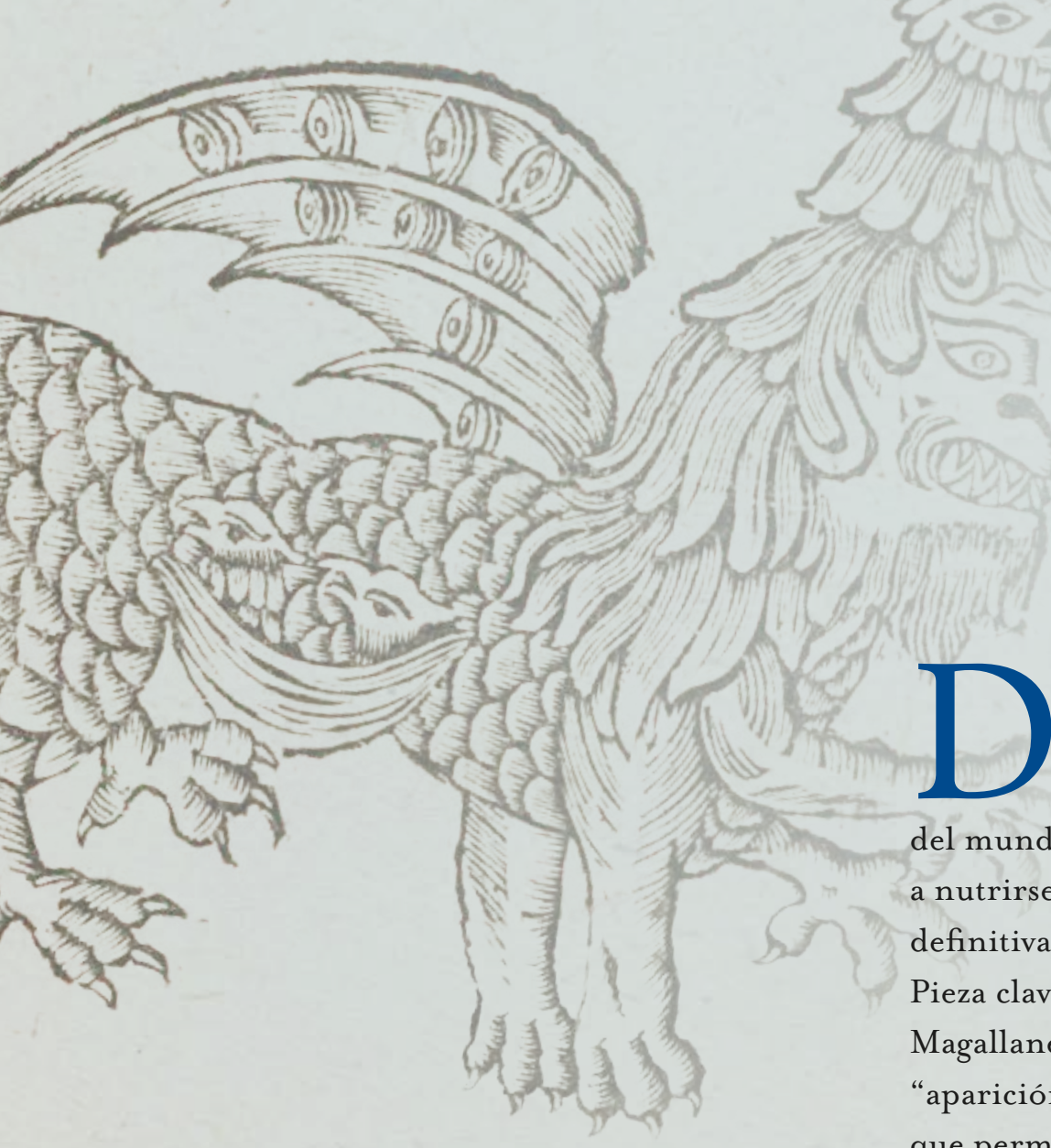

URANTE EL SIGLO XVI

se consagra un vínculo indisoluble: las "cuatro partes del mundo" empiezan a interactuar, a nutrirse unas de otras y a mestizarse definitivamente hasta el día de hoy. Pieza clave para esto es el estrecho de Magallanes, debido a que gracias a su “aparición” el planeta se completa, lo que permite que una conjunción de personas, de objetos y de imaginarios desde ese entonces se piensen de manera global. En otras palabras, son los nuevos límites espaciales y temporales que provoca el "descubrimiento" del Estrecho los que dan paso a que sucedan estos cambios. 
A partir de la revelación del pasajemundo observamos que se aceleraron las reflexiones sobre lo que significaba habitar la Tierra, lo que como humanidad se había construido en el tiempo, como también lo que significaba realmente este último concepto en dicha actualidad: el pasado en muchos casos se negó, el presente expandió sus horizontes y el futuro encontró nuevos referentes y lugares para ser especulado. Con lo anterior deseábamos dar a conocer cómo cada espaciotiempo se replanteó y, por ende, surgió la necesidad de una apropiación nueva de todos estos procesos. Por ejemplo, es así como pensamos que el control geopolítico-comercial se instaló como una ideología, que perturbó incluso la manera de observar a la propia humanidad.

Chile nunca estuvo desvinculado de todo este proceso que se generó desde el Estrecho. Al contrario, las tierras chilenas estuvieron constantemente conectadas con todas estas dinámicas. Es más, en muchas ocasiones sirvieron para fomentar la especulación (tierra de paso hacia la Terra Australis, los "secretos de la tierra" o la ciudad de los Césares) o para reforzar la idea de posesión en términos netamente geopolíticos (ataques piratas, resguardos de rutas comerciales, etc.).
Es debido a todas estas ideas que hemos expuesto, que nos ha parecido oportuno reflexionar brevemente sobre la importancia del Estrecho, como pasaje-mundo, en el siglo de su "descubrimiento". Nuestras interpretaciones corresponden a una de las tantas miradas que se pueden hacer sobre este pasaje fascinante. Con ellas, solo quisimos valorizar y mostrar lo necesario que es incorporar una parte de la historia del estrecho de Magallanes dentro del aprendizaje de lo que conocemos como Historia de Chile. Eso sí, no para fomentar aún más la excepcionalidad que se busca con las geografías que componen el territorio chileno, sino como un punto que demuestra que la historia no es un ejercicio nacional sino universal, que busca entender el devenir colectivo de mujeres y hombres a lo largo de los siglos, aunque sea desde puntos específicos del orbe. 


\section{Bibliografía}

BARROS ARANA Diego, Historia general de Chile, tomo I, II, Santiago, Editorial Universitaria, 2000.

BENAT-TACHOT Louise, “Alonso de Santa Cruz, un expert au service de l'Empire ?”, en O'Phelan, S. y Salazar-Soler, C. (Eds.) Passeurs, mediadores culturalesy agentes de la primera globalización en el mundo ibérico, siglos XVI-XIX, p. 679-7I2. Lima, Instituto Riva Agüero, Pontificia Universidad Católica de Lima y CNRS, IFEA, 2005.

BENAT-TACHOT LOUISE, "De la découverte à la politique : réflexions autour de la circumnavigation de Magellan dans La Historia de las Indias de Francisco López de Gómara, I552”, en Grunberg, B. (Dir.). Enjeux et difficultés d'un modèle européen dans les sociétés coloniales. Cahiers d'Histoire de l'Amérique coloniale, Vol. 2, Paris, L'Harmattan, 2007, p. I8I-20I.

BENAT-TACHOT Louise, “De l'ile à l'Islario: fonction et statut de l'île dans l'écriture de la conquête", en Trec, E (dir), Bout du voyage, l'ile: Mythe et réalité, Reims, Publications du Centre de Recherche VALS, Presses Universitaires de Reims, 200I, p. $56-87$.

BENAT-TACHOT LOUISE, "L'Antiquité pourvoyeuse de modèles pour la description du Nouveau Monde dans les chroniques des Indes”, en Bénat Tachot L. y Serge Gruzinski (Eds.) Passeurs culturels et mécanismes de métissage, Paris, Ed. MSH y Presses de l’Université de Marne-La-Vallée, 200I, p. 219-238.

BENITES MARÍA Jesús, “La mucha destemplanza de la tierra: Una aproximación al relato de Maximiliano de Transylvanus sobre el descubrimiento del Estrecho de Magallanes", Orbis Tertius, XVIII, I9, 20I3, p. 200-207.

BENTON Lauren, Law and Colonial Cultures: Legal Regimes in World History 1400-1900, New York, Cambridge University Press, 2002.

BERGREEN Laurenae, Par-delà le bord du monde. L'extraordinaire et terrifiant périple de Magellan, París, Grasset, 2005. 
BERNABÉU SALVADOR, Poblar la inmensidad: sociedades, conflictividady representación en los márgenes del Imperio Hispánico (siglos XV-XIX), Madrid, CSIC, 2010.

BERNARD Garmen y GRUZINSKI Serge, Histoire du Nouveau Monde. De la découvert à la conquête, tomo I, Paris, Fayard, I99I.

Bertrand Mighael, PRiOTti Jean Philippe., (dir.), Circulations maritimes. L'Espagne et son empire (XVIe-XVIIIe siècle), Rennes, Presses Universitaires de Rennes, $20 I I$.

BESSE JeAn-Marc, “Traverser le paysage au XVIe siècle”, en Revues parlées, Centre Pompidou, 2008.

BESSE JEAN-MARG, Les grandeurs de la Terre. Aspects du savoir géographique à la Renaissance, Lyon, ENS Éditions, 2003.

BLACK Jeremy, Maps and History: Constructing Images of the Past, Londres, Yale University Press, I997.

BLACK Jeremy, Maps and Politics, Londres, Reaktion Books, 2000.

BOIS Jean Pierre, L'Europe à l'époque moderne, XVIe-XVIIIe siècle, París, Armand Colin, 2003.

BRAUDEL FERnANd, La Méditerranée et le monde méditerranéen à l'époque de Philippe II, París, Armand Colin, I990.

BRENDEGKE ARNDT, Imperio e Información. Funciones del saber en el dominio colonial español, Madrid, Iberoamericana Vervuert, 2016.

BROTTON Jerry, A history of the world in 12 maps, Nueva York, Viking Adult, 2003.

BRY TeOdoro, América: 1590-1634, Madrid, Siruela, I992.

BUISSERET DAVID, Monarchs, Ministers and Maps: The Emergence of Cartography as a Tool of Government in Early Modern Europe, Chicago, The University of Chicago Press, I992.

BUISSERET DAVID, The mapmaker's quest: depicting new worlds in Renaissance Europe, Oxford, Oxford University Press, 2003.

BUSCHMANN RaIner, Iberian Visions of the Pacific Ocean, 1507-1899, Nueva York, Palgrave, 20I4.

CAÑIZARES-ESGUERRA Jorge, Puritan Conquistadors. Iberianizing the Atlantic, 1550-1700, Stanford, Stanford University Press, 2006. 
GARLTON GENEvieve, Worldly consumers: the demand for maps in Renaissance Italy, Chicago, The University of Chicago Press, 20I5.

GASTRO Xavier, Le voyage de Magellan (1519-1522). La relation d'Antonio Pigafetta \& autres témoignages, Paris, Chandeigne, 2007.

CHARTIER Roger, "La conscience de la globalité”, en Annales. HSS, n56, Vol. I, 200I, p. II9-I23.

CHAUNU Pierre, Conquête et exploitation des nouveaux mondes, Paris, Nouvelle Clio, I969.

CHAUNU Pierre, Seville et l'Amérique aux XVIème et XVIlème siècles, Paris, Flammarion, I977.

CUESTA Domingo Mariano, "Los Cronistas oficiales de Indias. De López de

Velasco a Céspedes del Castillo”, en Revista Complutense de Historia de América, vol. 33, 2007 , p. II5-I5O.

DAVIES SurekHa, Renaissance Ethnograpy and the Invention of the Human. New World, Maps and Monsters, Cambridge, Cambridge University Press, 2016.

DE SANTA GRUZ Alonso, Alonso de Santa Cruzy su obra cosmográfica, Madrid, Consejo Superior de Investigaciones Científicas, I983.

DICKSON Peter, The Magellan myth: reflections on Columbus, Vespucci, and the Waldseemueller map of 1507, Mount Vernon, Ohio, Printing Arts Press, 2007.

DOUKI Garoline y MINARD Philippe, "Histoire globale, histoires connectées: un changement d'échelle historiographique?", en Revue d'Histoire Moderne et Contemporaine, $\mathrm{n}^{\circ} 54,2007$, p. 7-2I.

ELLIOTT John, Empires of the Atlantic world: Britain and Spain in America, 1492-1830, Londres, Yale University Press, 2006.

ERGILlA Alonso, La Araucana, Alicante, Biblioteca Virtual Miguel de Cervantes, 2007.

ESTELLÉ PATRIGio y COUYOUMDJIAN RiGARDo, "La ciudad de los Césares: origen y evolución de una leyenda", Historia, n 7 , I968, p. 283-309.

FERNÁNDEZ DE OVIEDO Gonzalo, Historia Generaly Natural de las Indias, Islasy Tierra Firme del Mar Océano, Madrid, Imprenta de la Real Academia de la Historia, I85I.

FERNÁNDEZ-ARMESTO FELIPE, The Spanish Armada: the Experience of War in 1588, Londres, Oxford University Press, I989. 
FIORANI Francesca, The Marvel of Maps: Art, Cartography and Politics in Renaissance Italy, New Haven, Yale University Press, 2005.

FREEDLAN PAUL, Lo que vino de Oriente. Las especiasy la imaginación medieval, Valencia, Universitat de València, 2010.

GRAFTON Antony, New Worlds, Ancient Texts. The Power of Tradition and the Shock of Discovery, Cambridge, Harvard University Press, I995.

GRUZINSKI SERGE, "Les mondes mêlés de la Monarchie catholique et autres “connected histories" en Annales. HSS, n ${ }^{\circ 6}$, Vol. I, 200 I, p. 85-II7.

GRUZINSKI SERge, L'Aigle et le Dragon. Démesure européenne et mondialisation au XVIe siècle, París, Fayard, 2012.

GRUZINSKI SERge, Les quatres parties du monde. Histoire d'une mondialisation, Paris, Éditions de La Martinière, 2004 .

GUARDA GABriel, Flandes indiano: las fortificaciones del Reino de Chile: 1541-1826, Santiago, Ediciones Universidad Católica de Chile, I990.

HARTOG François, Régimes d'historicité. Présentisme et expériences du temps, Paris, Seuil, 2003.

HIATT Alfred, Terra Incognita. Mapping the Antipodes before 1600, Chicago, London, The University of Chicago Press, 2008.

HOFmann Gatherine, RiCHARD Hélèle, VAGNON Emmanuelle, The Golden Age of Maritime Maps: when Europe Discovered the World, New York, Firefly Books, 2013.

INVERNIZZI LUGíA, "La representación de la tierra de Chile en cinco textos de los siglos XVI y XVII”, en Revista Chilena de Literatura, n²3, I984, p. 5-37.

INVERNIZZI LUGíA, "Los trabajos de la guerra y los trabajos del hambre: dos ejes del discurso narrativo de la conquista de Chile (Valdivia, Vivar, Góngora Marmolejo)”, en Revista Chilena de Literatura, ${ }^{\circ} 36$, I990, p. 7-I5.

LA GALLE RiGARDO, "Los fuertes fronterizos chilenos. Resistencia e interacción en la frontera de Chile en los siglos XVI y XVII", en Espacio, Tiempoy Forma, n ${ }^{\circ} 8,2005$, p. 223-246. 
LAGUARDA Rolando, El hallazgo del Río de la Plata por Amerigo Vespucci en 1502, Montevideo, Biblioteca de la Academia Nacional de Letras, I982.

LÓPEZ DE GÓMARA FrANaisco, La historia general de las Indias, y todo lo acaecido en ellas desde que se ganaron hasta agora y la conquista de Mexico y de la Nueva España, Anveres, Martin Nucio, I554 .

LÓPEZ DE VELASGO JuAn, Geografíay descripción universal de las Indias. Recopiladas por cosmógrafo-cronista Juan López de Velasco desde el año de 1571 al de 1574, Madrid, Boletín de la sociedad geográfica de Madrid, Establecimiento tipográfico de Fortanet, I894.

MANNING PATRiak (ed.), World History. Global and Local Interactions, Princeton, Markus Wiener Publishers, 2006.

MARIÑO DE LOBERA PEdro, Grónica del reino de Chile, libro I, capítulo VI, Edición en formato electrónico a partir de Crónicas del reino de Chile, Madrid, Atlas, Biblioteca de Autores Españoles, I960. Disponible en/www. cervantesvirtual.com/obra-visor/ cro- nica-del-reino-de-chile--o/html/

MARTÍNEZ GAROLINA, "Relatos de viaje e imaginarios geográficos en la Cosmografía Universal (I556) de Guillaume Le Testu: apuntes para una arqueología textual”, Magallánica, Revista de Historia Moderna, Vol. 2 (4), 20I6, p. II8-I35.

MARTINIC Mateo, Cartografía magallánica 1523-1945, Punta Arenas, Ediciones de la Universidad de Magallanes, I999.

MARTINIC Mateo, Historia de la región magallánica, Punta Arenas, Ediciones de la Universidad de Magallanes, I992.

MARTINIC MATEO, Historia del estrecho de Magallanes, Santiago, Editorial Andrés Bello, I977.

MEDiNA José Toribio, Colección de documentos inéditos para la historia de Chile: desde el viaje de Magallanes hasta la batalla de Maipo: 1518-1818, Santiago, Imprenta Ercilla, I888-I902.

MENDIOLA Alfonso, "Un nuevo reto a la interpretación de las crónicas de la conquista historizar el concepto de experiencia", en Historiay grafía, n ${ }^{0} 20,2003$, p. I3-47.

MILLER NaOmi, Mapping the City: The Language and Culture of Cartography in the Renaissance, Londres, Continuum, 2003. 
MORE TOMÁs, L’Utopie, París, Flammarion, 1987.

MOREnO Rodrigo y GUARDA Gabriel, Monumenta Cartographica Valdiviensae, Santiago, Corporación Patrimonio Cultural de Ghile, 2010.

MORETTI Guillermo, "The Other World and the 'Antipodes': The Myth of the Unknown Countries between Antiquity and the Renaissance”, en Wolfgang H. y Meyer R. (Eds.), The Classical Tradition in the Americas (pp. 24I-284), Berlín, De Gruyter, I993.

MUNDY BARBARA, The Mapping of New Spain. Indigenous Cartography and the Maps of Relaciones Geográficas, Chicago, The University of Chicago Press, I996.

NADER Helen, Rethinking the World: Discovery and Science in the Renaissance, Bloomington, Lilly Library, I992.

O’GORMAn Edmundo, La invención de América, México, Fondo de cultura económica, I995 [I958].

OGARANZA NiGolás, "Herejes, saqueadores y bandidos de ultramar: la piratería en el virreinato del Perú. Siglos XVI-XVII”, en Cruz N. y Jaksic I. (Eds.). Seminario Simon Collier. Santiago: Pontificia Universidad Católica de Chile, 2005.

OÏFFER Aliae, "El Islario general de todas las islas del mundo (I560) de Alfonso de Santa Cruz o la ciencia cosmográfica en la España de Felipe II: en el Nuevo Mundo, el Caribe insular", en Savoirs en Prisme, nㄴ, 2012, p. I69-I87.

ONETTO PAVEZ Mauriaio, Temblores de tierra en el Jardín del Edén. Desastre, memoria e identidad. Chile, siglos XVI-XXI, Santiago, Centro de Investigaciones Diego Barros Arana, DIBAM, 2017.

ONETTO PAVEZ, Mauriaio, "La Utopía de Moro y la Isla Grande de Tierra del Fuego, ¿Una equivalencia posible?”, Magallania, vol.43, n.I, 20I5, p. 37-5I.

PADRÓN RICARDO, "Las Indias olvidadas: Filipinas y América en la cartografía imperial española”, Universidade de São Paulo $3^{\circ}$ Simpósio Iberoamericano de História da Cartografia Agendas para a História da Cartografia Iberoamericana, São Paulo, 2010.

PADRÓN Ricardo, "Mapping Plus Ultra: Cartography, Space, and Hispanic Modernity", Representations, n79, 2002, p. 28-60.

PADRÓN RIGARDO, The Spacious Word: Cartography, Literature, and Empire in Early Modern Spain, Chicago, University of Chicago Press, 2004. 
PAGDEN Anthony, Spanish Imprerialism and the political imagination. Studies and Spanish-American social and political theory 1513-1830, New Haven, Yale University Press, I990.

PARKER Gharles, Global Interaction in the Early Modern Age, Cambridge, Cambridge University, 2010.

PASTOR Beatriz, Discurso Narrativo de la conquista de América, La Habana, Edición Casa de las Américas, I983.

PETERS EDWARD, "The Desire to Know the Secrets of the World. Journal of the History of Ideas”, 62 (4), p. 593-6io.

PIGAFETTA ANTONIO, Le premier tour du monde de Magellan, introduction, postface et notes par Léonce Peillard, París, Éd. Tallandier, I993.

PIZARRO Y ORELLANA FERNANDO, Varones ilustres del Nuevo Mundo:

descubridores, conquistadores, y pacificadores del opulento, dilatado, y poderoso Imperio de las Indias occidentales: sus vidas, virtud, valor, hazañas y claros blasones, Madrid, Diego Díaz de la Carrera, I639.

PORTUONDO GAMBA MARÍA, Ciencia Secreta. La cosmografía españolay el Nuevo Mundo, Madrid, Iberoamericana Editorial Vervuert, 2013.

RAMÓN Armando De, Descubrimiento de Chile y compañeros de Almagro, Santiago, Ediciones de la Universidad Católica de Chile, I953.

RANDLES WILLIAM, Geography, cartography and nautical science in the Renaissance: the impact of the great discoveries, Aldershot, Ashgate, 2000.

RAYNAL Guillaume Thomas, Histoire philosophique et politique des établissements des Européens dans les deux Indes, tomo IV, Genève, Ghez J-L Pellet, I78I.

RUSSO Alessandra, El Realismo Circular, Tierras, espaciosy paisajes de la cartografía indígena novohispana, siglos XVIey XVIIe, México, UNAM, Instituto de Investigaciones Estéticas, 2005 .

SAGREDO RAFAEL, "Magallanes: de la geografía mundial a patrimonio históricogeográfico de Chile”, en Tramas de la diversidad. Reflexiones, debatesy propuestas en torno al patrimonio en Chile, Santiago, Consejo Nacional de la Cultura y las Artes, p. I57-I70. 
SALlamanN Jean Miahel, Géopolitique du XVIe siècle, 149o-1618, Paris, 2003.

SCAFI Alessandro, Maps of Paradise, Chicago, London, The University of Chicago Press, 20I3.

SLOTERDIJK Peter, Esferas II. Globos, Madrid, Ediciones Siruela, 2004.

SOLANO FRANGISGO, Cuestionarios para la formación de las relaciones geográficas de Indias, siglo XVI-XIX, Madrid, Consejo Superior de Investigaciones Científicas/Centro de Estudios Históricos, 1998.

SUBRAHMANYAM SANJAY, "Holding the World in Balance: The Connected Histories of the Iberian Overseas Empires, I500-I640”, The American Historical Review, vol. II2, 2007, p. 5 .

SUBRAHMANYAM SANJAY, "On World Historians in the Sixteenth Century", Representations, ${ }^{\circ}$ 9I, Vol I, 2005, p. 26-57.

SUBRAHMANYAM SAnjay, Explorations in Connected History. From the Tagus to the Ganges, Oxford, Oxford University Press, 2005.

SUBRAHMANYAM SANJAY, L'empire portugais d'Asie, 1500-1700, Paris: Points, 2013.

TEPASKE John, “The Costs of Empire: Spending Patterns and Priorities in Colonial Peru, I58I-I820”, CLAHR, n² 2, Vol. I, I993.

UNGER RIGHARD, Ships on maps: pictures of power in Renaissance Europe, Basingstoke, Palgrave Macmillan, 2010.

URBINA MARÍA XIMENA, La frontera de arriba en chile colonial. Interacción hispano-indígena en el territorio entre Valdivia y Chiloé e imaginario de sus bordes geográficos, 1600-180o, Valparaíso, Ediciones Universitarias de Valparaíso, 2009.

VALDIVIA Pedro, Cartas de Don Pedro de Valdivia que tratan del descubrimiento y conquista de la Nueva Extremadura [Edición a cargo de Miguel Rojas-Mix], Barcelona, Editorial Lumen, I99I.

VAN DUZER Ghet, Sea monsters on medieval and Renaissance maps, Londres, The British Library, 20I3.

VEGA Alejandra, Los Andes y el territorio de Chile en el siglo XVI. Descripción, reconocimiento e invención, Santiago, DIBAM, 20I4. 
VESPUCGI Amerigo, Le Nouveau Monde. Les voyages d'Amerigo Vespucci (1497-1504), Paris, Chandeigne, 2005.

WOODWARD DAVId, Cartography in the European Renaissance, Ghicago, University of Chicago Press, 2007.

ZÁRATE Agustín de, Historia del descubrimiento y conquista del Perú, Primera Serie, Lima, Biblioteca Peruana, Editores Técnicos Asociados S.A., I968.

ZULETA, Joaquín, Pedro Sarmiento de Gamboa. Sumaria Relación, Navarra, Editorial Iberoamaricana, 2015 .

ZUÑIGA Jean Paul, Espagnols d'Outre-mer. Emigration, Métissage et reproduction sociale à Santiago du Chili au XVIIe siècle, Paris, Édition de l’École des Hautes Études en Sciences Sociales, 2002. 


\section{Archivos y bibliotecas consultadas}

Archivo Nacional de Chile.

Biblioteca Nacional de Chile-Sala Medina.

Harvard Library.

Library of Congress, Washington.

The John Garter Brown Library.

Archivo General de Indias.

Biblioteca Nacional de España.

Biblioteca Nacional de Francia.

Biblioteca de la Universidad Paris-Sorbonne.

The British Library.

Cambridge University Library. 
